\author{
UNIVERSIDADE DE SÃO PAULO \\ ESCOLA DE COMUNICAÇÕES E ARTES
}

EDNA LUCIA MARTINS DANTAS

\title{
Intercâmbio Cultural Cidade-Campo: \\ Uma experiência de ensino da arte em um assentamento do Movimento dos Sem-Terra e uma escola pública da cidade de São Paulo
}


AUTORIZO A REPRODUÇÃO E DIVULGAÇÃO TOTAL OU PARCIAL DESTE TRABALHO, POR QUALQUER MEIO CONVENCIONAL OU ELETRÕNICO, PARA FINS DE ESTUDO E PESQUISA, DESDE QUE CITADA A FONTE

Catalogação na Publicação

Biblioteca da Escola de Comunicações e Artes

Departamento de Artes Plásticas da Universidade de São Paulo

\section{Dantas, Edra Lucia Martins.}

Intercâmbio Cultural Cidade-Campo: Uma experiência de ensino da arte em um assentamento do Movimento dos Sem-Terra e uma escola pública da cidade de São Paulo / Edra Lucia Martins Dantas ; orientadora Regira Stela Barcelos Machado. - São Paulo, 2008.

$106 \mathrm{f}$.

Dissertação (Mestrado - Fundamentos do Ensino e Aprendizagem em Arte). Área de concentraçä́o: Teoria, Ensino e Aprendizagem da Arte) - Departamento de Artes Plásticas, Universi dade de São Paulo.

1. Ante-ecucação. 2. Artes plásticas. 3. Letramento. 4. Escola Pública. 5. Movimento dos Sem-Terra 6. Intercâmbio cultural. 
EDNA LUCIA MARTINS DANTAS

\section{Intercâmbio Cultural Cidade-Campo: \\ Uma experiência de ensino da arte em um assentamento do Movimento dos Sem-Terra e uma escola pública da cidade de} São Paulo

Dissertação de Mestrado em Fundamentos do Ensino e Aprendizagem da Arte, apresentada ao Programa de Pós-graduação em Teoria, Ensino e Aprendizagem da Arte da Escola de Comunicações e Artes da Universidade de São Paulo - ECA-USP como parte dos requisitos necessários à obtenção do título de Mestre em Artes Visuais.

Área de Concentração: Teoria, Ensino e aprendizagem da arte.

Linha de Pesquisa: Fundamentos do Ensino e Aprendizagem da Arte.

Orientadora: Prof ${ }^{\mathrm{a}} \mathrm{Dr}^{\mathrm{a}}$ Regina Stela Barcelos Machado

São Paulo

2008 
FOLHA DE APROVAÇÃO

Edna Lucia Martins Dantas

\section{Intercâmbio Cultural Cidade-Campo: \\ Uma experiência de ensino da arte em um assentamento do Movimento dos Sem-Terra e uma escola pública da cidade de São Paulo}

Dissertação de Mestrado em Fundamentos do Ensino e Aprendizagem da Arte, apresentada ao Programa de Pós-graduação em Teoria, Ensino e Aprendizagem da Arte da Escola de Comunicações e Artes da Universidade de São Paulo - ECA-USP como parte dos requisitos necessários à obtenção do título de Mestre em Artes Visuais.

Área de Concentração: Teoria, Ensino e aprendizagem da arte.

Aprovada em:

Banca Examinadora

Prof. Dr.

Instituição:

Assinatura

Prof. Dr.

Instituição

Assinatura

Prof. Dr.

Instituição Assinatura 
Este trabalho é dedicado ao meu pai, Lindolfo Rodrigues Dantas, minha melhor referência de solidariedade humana. 
Agradeço a Deus e aos meus familiares que vibraram por mim durante esta caminhada.

À minha mãe, Emerita Martins Dantas, pelo exemplo de vida, e à Angela, minha razão de viver.

À minha orientadora, Regina Machado, pela docilidade, sabedoria e sensibilidade.

À Ana Mae Barbosa, por sua grande e árdua missão de defender o ensino da arte no Brasil, pela força e pela energia que me inspira e me encoraja.

À Prof ${ }^{\mathrm{a}} \mathrm{Dr}^{\mathrm{a}}$ Dilma de Melo, pela sua atenção e colaboração tão amorosa.

Às educadoras e parceiras que colaboraram para a realização deste trabalho, Leonora, Magda, Maro, Márcia e Kátia.

A todos os educandos, crianças, jovens e adultos da cidade e do campo, que participaram desta aventura, se emocionaram e deixaram seus registros.

Aos amigos da Agrovila III, que gentilmente me hospedaram e me acolheram em seus lares.

A vocês e a todos os não citados, o meu sincero agradecimento. 


\section{RESUMO}

DANTAS, Edna Lucia Martins. Intercâmbio cultural cidade-campo: Uma experiência de ensino da arte em um assentamento do Movimento dos Sem-Terra e uma escola pública da cidade de São Paulo. 2008. 106 f. Dissertação (Mestrado em Fundamentos do Ensino e Aprendizagem da Arte) - Departamento de Artes Plásticas, Universidade de São Paulo, São Paulo, 2008.

A presente dissertação relata uma experiência de intercâmbio cultural entre educandos de uma escola pública da cidade de São Paulo e educandos de um assentamento do Movimento dos Sem Terra na cidade de Itaberá-SP, por meio da arte, da leitura e da escrita, baseada em teorias de ensino-aprendizagem em educação e arte. Esta proposta, inspirada no Programa Escolas-Irmãs (uma vertente da Mobilização Social do Programa Fome Zero do Governo Federal), visa conhecer como os educandos da cidade e do campo se expressam, através da arte, da leitura e da escrita, mediante a troca de correspondências, e possibilitar aos educandos uma integração e respeito mútuo. A iniciativa do projeto de intercâmbio partiu do ensino da arte e ocorreu no decorrer do ano letivo de 2007, sem envolvimento com toda a comunidade escolar, portanto trata-se de um recorte sobre o ensino da arte e apenas aponta um caminho que não se esgota nesta pesquisa.

Palavras-chave: arte-educação, artes plásticas, letramento, escola pública, movimento dos Sem-Terra, intercâmbio cultural. 


\begin{abstract}
DANTAS, Edna Lucia Martins. Cultural exchange city-countryside. The teaching of art between the MST and a public school in the Sao Paulo city, in a spiral of learning. 2008. 106 f. Dissertação (Mestrado em Fundamentos do Ensino e Aprendizagem da Arte) Departamento de Artes Plásticas, Universidade de São Paulo, São Paulo, 2008.
\end{abstract}

This dissertation reports an experience of cultural exchanges between students of a public school in the Sao Paulo city and students of a Landless Movement's settlement in the city of Itaberá-SP. Through art, reading and writing, based on theories of teaching-learning in education and art. This proposal, based on the Schools Program-sisters (one aspect of the Zero Hunger Program's Social Mobilization from Federal Government's), is known as the students from the city and the field are expressed through art, reading and writing, through the exchange of correspondence, and enable to students integration and mutual respect. The exchange project initiative started the teaching of art and occurred during the academic year of 2007, without involvement with the entire school community, therefore it is a cut on the teaching of art and only shows a path that goes beyond this search..

Keywords: art education, arts, literacy, public school, Sem-Terra Movement, cultural exchange. 


\section{SUMÁRIO}

INTRODUÇÃ

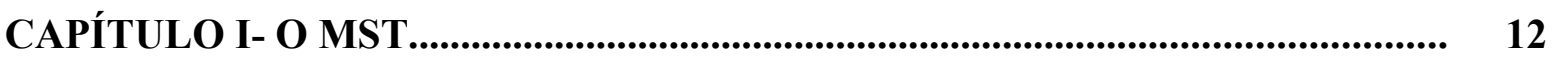

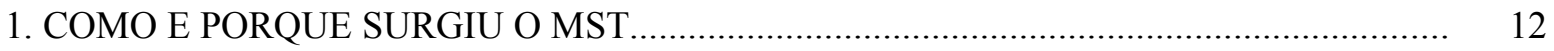

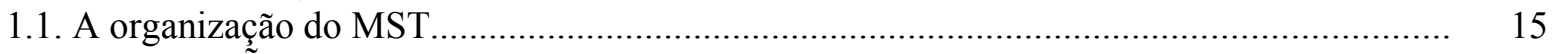

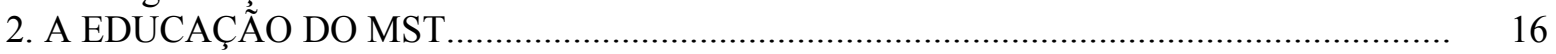

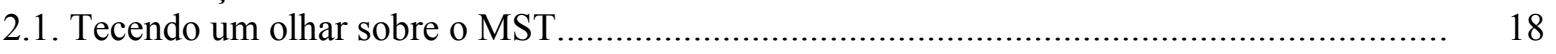

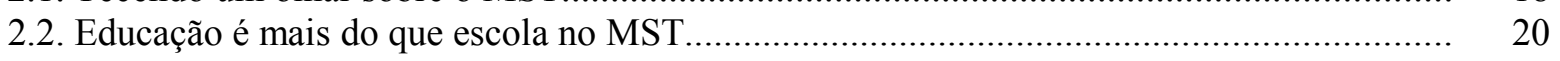

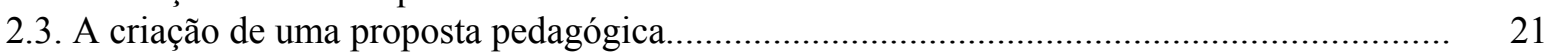

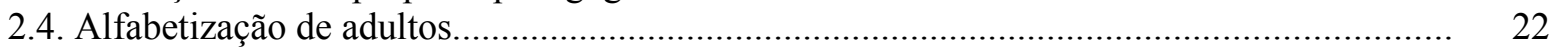

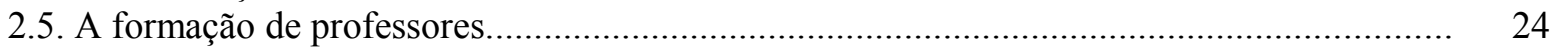

2.6. As matrizes pedagógicas do movimento ......................................................................... 25

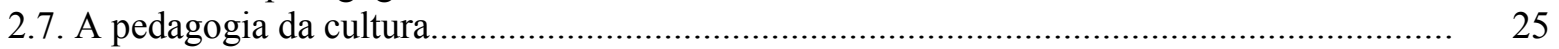

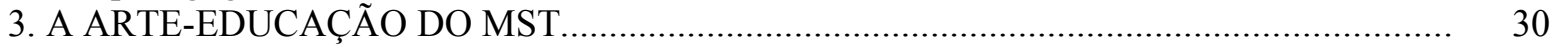

CAPÍTULO II - O ENSINO DA ARTE......................................................................... 33

1. O ENSINO DA ARTE NO BRASIL E A PROPOSTA TRIANGULAR .................... 33

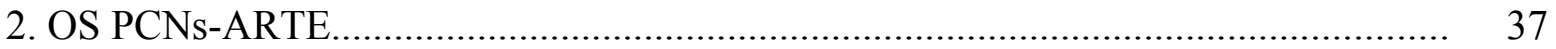

3. O ENSINO DE ARTES EM SÃO PAULO........................................................ 38

3.1. A leitura e escrita em artes............................................................................... 40

3.1.1. Antes da leitura de uma imagem: aquecer o olhar............................................. 42

3.1.2. Durante a leitura de uma imagem: olhar......................................................... 43

3.1.3. Depois da leitura da imagem: olhar além....................................................... 47

4. O EDUCANDO DA EMEF COMANDANTE GASTÃO MOUTINHO................... 56

CAPÍTULO III - O INTERCÂMBIO CULTURAL CIDADE-CAMPO...................

1. O ENSINO DA ARTE NUMA ESPIRAL DE APRENDIZAGEM.......................... 61

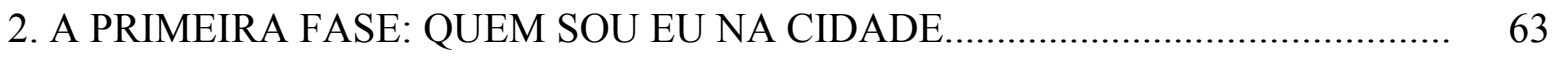

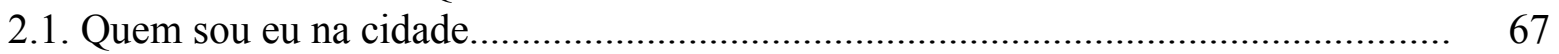

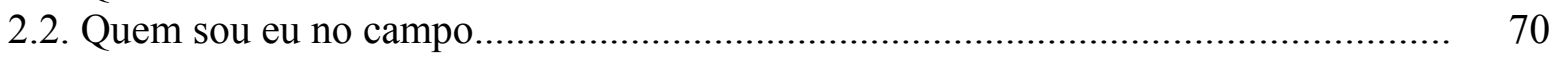

2.3. A experiência com as crianças do ciclo I.......................................................... 72

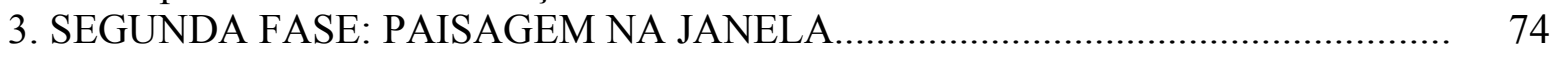

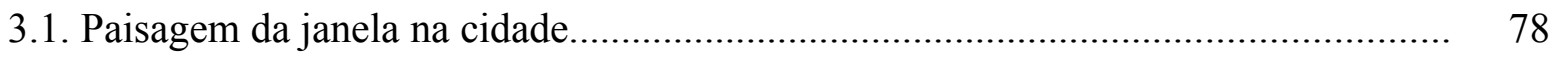

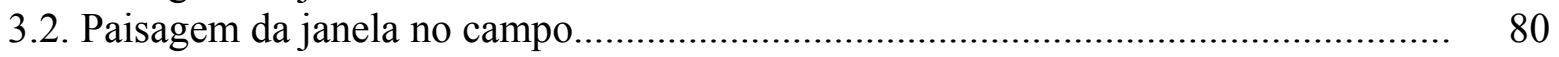

4. TERCEIRA FASE: ARTE E MEIO AMBIENTE ............................................ 81

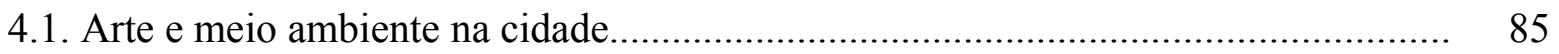

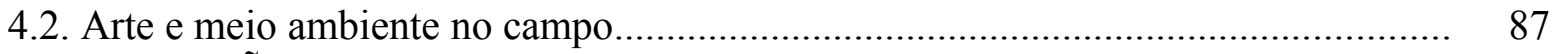

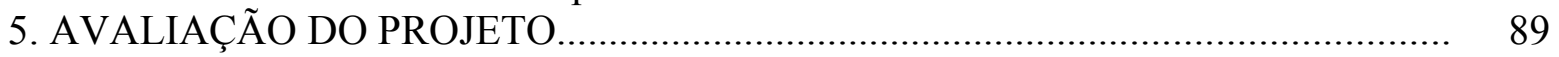

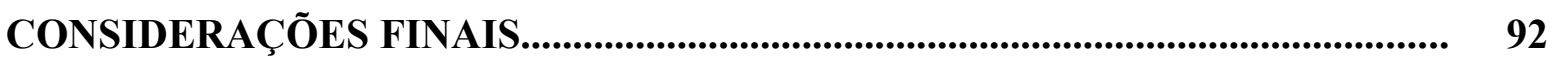

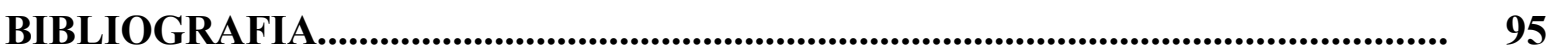




\section{INTRODUÇÃO}

Em 2003, com a eleição de Lula para Presidente da República, cresceu a esperança de um país mais justo, com menos desigualdade e melhor qualidade de vida. Frei Betto assumiu o cargo de assessor especial da Presidência do Brasil para assuntos sociais, e seu papel foi cuidar do programa Fome Zero, que consiste em uma série de ações para diminuir a fome e a miséria no Brasil. Dentre as iniciativas, o programa Escolas Irmãs ${ }^{1}$ propõe o intercâmbio entre escolas, para que os educandos conheçam as diferentes realidades do seu País.

A possibilidade de colocar em contato direto educandos da cidade e do campo motivou a elaboração desta proposta, através da troca de correspondências, os educandos contam como vivem e pensam, falam sobre o seu dia-a-dia, sua família, sua comunidade, seus sonhos e projetos, falar sobre a escola, a educação, as preocupações dos jovens e as questões inerentes à sua idade.

O objetivo desta pesquisa foi fazer um diálogo entre o campo e a cidade através do ensino da arte, da escrita e da leitura, e desta aproximação humanizar as relações, socializar o conhecimento e desenvolver a solidariedade e o respeito humano. Quem vive no campo tem algo a ensinar para quem vive na cidade e vice-versa, portanto é preciso saber: quem é o educando do Movimento dos Sem Terra, ${ }^{2}$ e quem é o educando da cidade; qual o sentido educativo da arte na educação do MST e na educação da cidade; que valores culturais são passados aos educandos por meio do ensino da arte nas escolas e no Movimento; de que forma a troca de experiências/correspondências entre as crianças do MST e da cidade poderá contribuir para o seu crescimento humano.

O intercâmbio cultural propõe a troca de correspondências entre os educandos de um assentamento com os educandos de uma escola pública da cidade de São Paulo, por meio da linguagem visual, da leitura e escrita e dos recursos da tecnologia da informação (computadores, vídeos, TVs, fotografias etc.) disponíveis. O intercâmbio é uma metodologia de pesquisa de campo, proposta para complementar a pesquisa teórica previamente realizada,

\footnotetext{
1 O Programa Escolas Irmãs foi apresentado na palestra proferida em São Paulo no Fórum Mundial de Educação em 2004, com distribuição de cartilhas para educandos e educadores.

${ }^{2} \mathrm{O}$ Movimento dos Trabalhadores Rurais Sem-Terra, tornou-se conhecido no Brasil e no mundo como Movimento dos Sem Terra, com letras maiúsculas e sem hífen. No texto, usarei a sigla MST para se referir ao Movimento.
} 
com o objetivo de criar um relacionamento entre crianças e jovens da cidade e do campo com hábitos, valores e culturas diferentes dentro do próprio País.

Ao promover o intercâmbio cultural entre educandos do campo e da cidade e observar como vivem, pensam e se expressam por meio da arte, da leitura e da escrita, objetivou-se proporcionar uma nova experiência, com a ampliação do repertório cultural de todos os educandos pela igualdade social, pelo respeito à pluralidade cultural, pela autonomia e pelo protagonismo juvenil como forma de incentivo à comunicação e à livre expressão do pensamento. Como diz Leonardo Boff, "cada um lê com os olhos que têm e interpreta a partir de onde os pés pisam. Todo o ponto de vista é um ponto" (BOFF, 1997 p. 9). A pesquisa foi realizada com educandos do ciclo II do ensino fundamental da EMEF Comandante Gastão Moutinho, na cidade de São Paulo, e educandos de 7 a 70 anos da Agrovila III, um assentamento do MST na cidade de Itaberá-SP.

A pesquisa está estruturada em três capítulos. O primeiro é dedicado a conhecer e compreender em que contexto surgiu o MST, as causas dessa luta, quem são seus protagonistas, como e o que os motiva a permanecer na luta, a influência de Paulo Freire na sua concepção de educação, a sua pedagogia e a pedagogia da cultura, sua arte e sua mística.

O segundo capítulo faz uma abordagem sobre o ensino da arte a partir da Proposta Triangular de Ana Mae Barbosa, dos PCNs de arte, e das orientações para o ensino da arte na rede municipal de São Paulo, embasados no pensamento contemporâneo sobre o ensino da arte que reconhece arte como área do conhecimento e resgata sua importância na formação do educando.

No terceiro capítulo, faço uma síntese dessas metodologias e desenvolvo uma experiência de ensino da arte, fazendo um intercâmbio cultural entre os alunos da EMEF Cte. Gastão Moutinho na cidade de São Paulo, onde fui professora durante o ano letivo de 2007, e os educandos da Agrovila III, um assentamento do MST em Itaberá, no Estado de São Paulo. Para contextualizar o projeto, apresento o perfil socioeducativo dos educandos da cidade e do campo.

O projeto foi dividido em três fases, que foram apresentadas no decorrer de um ano letivo nas duas comunidades, por meio de reproduções, fotografias, livros, catálogos e calendários de arte de vários períodos, gêneros e artistas, apresentações em Power Point, por meio da informática, músicas e poesias, de folhetos de exposições de arte e de vídeos. Em 
cada fase, ao promover a fuição das obras, tinha a intenção de promover o autoconhecimento, a percepção do seu espaço e a consciência do meio ambiente urbano e rural.

A realização deste trabalho não teria sido possível sem o apoio de educandos e educadores das instituições de ensino, do assentamento Agrovila III e da minha família, que compreenderam a importância deste projeto não só para o ensino da arte como também para transformar a educação numa relação humanizadora. Em especial, agradeço à professora Leonora, da Sala de Informática, uma parceira sensível e competente, que diante de tantas demandas na sua única aula semanal com cada turma, reconheceu a importância deste projeto no papel transformador da educação. Sua vibração e seu envolvimento foram imprescindíveis para que o projeto transcendesse a sala de aula para o campo da hipermídia e da intertextualidade. Agradeço ao MST, pelo acolhimento de uma pessoa estranha ao Movimento, em especial ao professor Dr. Bernardo Mançano Fernandes, da UNESP de Presidente Prudente, à Coordenação Estadual de Educação, ao Coletivo de Cultura do MST e à Escola Técnico-Agricola da cidade de Itaberá-SP, pelo vasto material bibliográfico em livros e teses com conteúdos tão inusitados que, em geral, até me desviavam do objetivo da pesquisa.

Agradeço especialmente à professora Ana Mae Barbosa, pelo envio do seu artigo escrito sobre o ensino da arte no MST, que muito enriqueceu minha pesquisa; sei que mesmo à distância ela torceu por mim e acreditou no meu trabalho; ao incentivo da professora Dilma de Melo, por me colocar nos "eixos", indicando um caminho; às professoras Christina Rizzi e Rejane Coutinho, pela paciência em ler um texto ainda tão confuso no exame de qualificação; graças às suas 'adverências' e aos seus conselhos eu consegui encontrar um caminho. Finalmente, não poderia deixar de externar minha eterna gratidão à professora Regina Machado, minha querida orientadora, cuja paciência e fé (com algumas recaídas), ajudou a transformar uma idéia em uma experiência consumatória. 


\title{
CAPÍTULO I - O MST
}

\section{COMO E PORQUE SURGIU O MST}

\author{
(...) Os sem-terra afinal \\ Estão assentados na pleniposse da terra: \\ De sem-terra passaram a \\ Com-terra: ei-los (...) \\ Haroldo de Campos, 1998
}

A história do MST se compara com as históricas luta do povo desde o descobrimento em 1500, marcado pela concentração de terras, como os quilombos, Canudos, Contestado, as Ligas Camponesas, as lutas de Trombas e Formoso, a Guerrilha do Araguaia, entre muitas outras que aconteceram no Brasil, segundo Morisawa (2001). ${ }^{3}$

No início dos anos de 1980, o País vivia um momento de abertura política, após 20 anos de ditadura militar, com o apoio de interesses econômicos internacionais e da elite dominante dos grandes latifúndios contra as ligas camponesas do Norte e Nordeste e os Movimentos dos Agricultores Sem-Terra (MASTER) da Região Sul do País. Aos poucos, a sociedade civil retomou seus ideais de liberdade e começou a se reorganizar em movimentos sociais, associações de classe e sindicatos de trabalhadores. No campo, os movimentos sociais começaram a se articular para lutar pela reforma agrária, garantir o direito de permanecer na terra e produzir seus próprios alimentos. (FERNANDES, 2001). Lutar contra o latifúndio era como a luta de Golias contra os leões, pois além das terras tinham o poder político e econômico, capaz de financiar um forte esquema de segurança privada (os jagunços), o sistema judiciário e os meios de comunicação.

Os colonos do Rio Grande do Sul, remanescentes do Movimento dos Agricultores Sem-Terra (MASTER), insatisfeitos com essa política, em 1978 recusaram-se a deixar sua região em troca de terras no Mato Grosso, retornaram ao Sul e acamparam na região de

\footnotetext{
3 Mitsue Morissawa. A história da luta pela terra e o MST. Editora Expressão Popular, 2001. In Agenda MST 2006. História do MST.
} 
Nonoai. Sem as terras, com o empobrecimento dos trabalhadores, os colonos passaram a se reorganizar, e a partir de 1978 começaram a surgir lutas sociais por todo País. Paralelamente aos movimentos sociais históricos ligados à produção, surgiram outros movimentos ligados a causas específicas, como os movimentos feministas, dos negros, dos homossexuais, além de movimentos ecológicos, pela anistia, contra a carestia, por creches etc. (BERGER, 1996).

Porém, desde a década de 1970, em plena Ditadura Militar, a Igreja Católica se dividiu, e um dos setores da Igreja fez sua opção pelos pobres. D. Pedro Casaldáglia, um bispo espanhol, escolheu a prelazia de São Félix do Araguaia, em Goiânia, uma região de muitos conflitos de terra na década de 1970, e em plena Ditadura Militar criou a Comissão Pastoral da Terra, que junto com os trabalhadores do campo ajudou a organizar os trabalhadores rurais para que eles permanecessem no campo, resistindo às pressões do sistema econômico de concentração de terras e expulsão do homem do campo. Na mesma época, Leonardo Boff $f^{4}$ lançou a Teologia da Libertação ${ }^{5}$, cuja base está na opção por Deus e pelos pobres conscientizados e organizados, sujeitos de sua transformação.

Entre as muitas funções da teologia, hoje em dia, duas são mais urgentes: como a teologia colabora na libertação dos oprimidos que são nossos cristos crucificados hoje e como a teologia ajuda a preservar a memória de Deus para que não se perca o sentido e a sacralidade da vida humana, ameaçada por uma cultura da superficialidade, do consumo e do entretenimento (BOFF, 1997). ${ }^{6}$

De 1979 a 1984, surgiram os primeiros grupos de trabalhadores rurais e de 21 a 24 de janeiro de 1984, realizou-se o Primeiro Encontro Nacional de Trabalhadores Sem-Terra, em Cascavel, no Estado do Paraná, com o apoio das Pastorais Sociais da Igreja Católica Comissão Pastoral da Terra - CPT, Pastoral Operária - PO, quando então ocorreu a fundação do MST para a resolução de problemas concretos e da mobilização contra o regime militar e promover as primeiras ocupações com o lema "Sem reforma agrária não há democracia".

Em 1985, quando o País todo se mobilizava na campanha pelas Diretas e por uma nova Constituição, ocorreu o I Congresso Nacional do MST, em Curitiba-PR. No Congresso

\footnotetext{
${ }^{4}$ Leonardo Boff é assessor das comunidades eclesiais de base (CEB) e de movimentos sociais, professor de Ética, Filosofia da Religião e Ecologia da UERJ e autor de mais de 60 livros, traduzidos em vários idiomas. Sua grande contribuição ao MST está nas "místicas"

5 Por defender esta causa sentou-se diante do tribunal da ex-inquisição de Roma, o mesmo que condenou Galileu, e em 1985 foi condenado a um "silêncio obsequioso" e deposto de suas funções pelo Vaticano, pena esta suspensa em 1986 por pressões internacionais. Em 1992, sentindo-se novamente ameaçado e impedido de colocar suas idéias, decide renunciar às atividades de padre, mas não de sua causa como teólogo da libertação. Disponível em: $<\mathrm{http}: / / w w w . f l y . t o /$ Boff $>$. Acesso em: 20 jun. 2007.

${ }^{6}$ Disponível em: $<$ http://www.leonardoboff.com/site/teo/teo.htm>. Acesso em: 20 out. 2007.
} 
definiu-se as diretrizes que iriam nortear o Movimento, organização em forma de coletivos e setores $^{7}$ e pela participação direta na política. O congresso marcou um período de afirmação com a definição de seus símbolos, do hino e da bandeira. A força do movimento se confirmou nas eleições de 1986 a eleger seus próprios representantes para cargos políticos nas regiões onde “(...) a questão da terra; representa um problema central a ser resolvido, sugere alguns aspectos para reflexão (...)" (BRUMER apud BERGER, 1996). Tratou-se, em resumo, de examinar a eficácia política dos sem-terra, por meio da utilização dos canais legais de poder. Um deputado estadual e um deputado federal ${ }^{8}$; 97 vereadores e três prefeitos no Rio Grande do Sul pelo Partido dos Trabalhadores. Segundo a Coordenação Nacional do Movimento, estima-se que havia no Brasil 14 milhões de agricultores Sem-Terra e 77 mil hectares de terras não-cultivadas que foram ocupadas por trabalhadores rurais.

Em 1990, realizou-se o II Congresso do MST, em Brasília-DF, para ampliar o debate sobre a organização interna, as ocupações e a expansão no Território Nacional. Mesmo sem projeto de reforma agrária, enfrentando ações dos latifundiários, o MST seguiu o lema dos anos 1990, que era “Ocupar, resistir e produzir”. (BERGER, 1996)

Em 1995 realizou-se o III Congresso Nacional do MST. Em Brasília. O MST começou a ser identificado como referência para os outros movimentos populares da cidade e dividiu a opinião pública. Apesar do poder da mídia, os movimentos sociais continuaram crescendo, assim como a consciência da importância da reforma agrária como alternativa para o campo e solução para o País. Mas eles precisavam do apoio da cidade, dos trabalhadores e das trabalhadoras da cidade, portanto a palavra de ordem deste congresso foi "Reforma Agrária, uma luta de todos". O Congresso apresentou uma nova forma de organizar a produção, nem camponesa, nem capitalista, nem coletivista, e sim uma reorganização do meio rural e democratização da terra e do conhecimento. Por meio da agroindústria tornou-se possível romper o medo de ser camponês, ao agregar valor e vender a produção com menor custo.

Em 1997, a "Marcha Nacional por Emprego, Justiça e reforma Agrária", organizada pelo MST, reuniu milhares de sem-terra de todo o Brasil. Saiu de vários pontos do País, a

\footnotetext{
7 No MST não há uma liderança, nas assembléias são escolhidos três coordenadores que se destacam pela sua atuação para cuidar de um determinado Setor que mais se identifica como o Setor de Educação. Os coordenadores atuam em várias instâncias, desde o acampamento, no assentamento, na região, no estado e a nível Nacional.

8 Ao eleger um deputado federal, Adão Preto o MST garantiu sua participação na Assembléia Constituinte, mas ganhou um forte opositor, Rodaldo Caiado da UDR.
} 
exemplo da Coluna Prestes ${ }^{9}$, passando por várias cidades, com destino a Brasília, com o apoio e a solidariedade de doações recebidas. A chegada a Brasília, no dia 17 de abril, coincidiu com um ano após o massacre de Eldorado dos Carajás, quando 19 sem-terra foram assassinados pela polícia. Este fato (tanto o massacre como a marcha) teve repercussão internacional e mostrou como os conceitos de Justiça e direito no Brasil se confundem em detrimento dos pobres e dos despossuídos. O massacre foi registrado por Sebastião Salgado e está no seu livro Terra.

\subsection{A organização do MST}

O MST está organizado em 24 Estados do Brasil e segue os mesmos objetivos definidos nesse Encontro e ratificados no I Congresso Nacional realizado em 1985 em Curitiba, no Paraná. São três os principais objetivos do Movimento: 1) redistribuir terra para aqueles que nela trabalham; 2) construir a reforma agrária - que para o MST é algo muito maior e mais complexo do que a simples redistribuição de terra; 3) construir uma sociedade socialista. A estratégia do MST consiste em promover ocupações de latifúndios improdutivos com manifestações públicas e passeatas, como forma de pressionar o governo a colocar a reforma agrária na agenda política brasileira, com acesso ao crédito agrícola, assistência técnica e infra-estrutura para novos assentamentos. Milhares de famílias já foram assentadas, já produzem alimentos, formam cooperativas e agroindústrias, erradicando a fome e os altos índices de mortalidade infantil nos assentamentos espalhados pelo Brasil.

Sua estrutura organizacional se baseia em uma verticalidade iniciada nas brigadas (compostas por 50 famílias) e seguindo pelos núcleos (grupo de 200 famílias), direção regional, direção estadual e direção nacional. Paralelo a essa estrutura existe outra, a dos setores e coletivos, que buscam trabalhar cada uma das frentes necessárias para a reforma agrária verdadeira. São setores do MST: saúde, direitos humanos, gênero, educação, cultura, comunicação, formação, projetos e finanças, produção, cooperação e meio ambiente e frente de massa. São coletivos do MST: juventude e relações internacionais. Esses setores desenvolvem alternativas às políticas governamentais convencionais, buscando sempre a perspectiva camponesa. (MST, 2005).

Hoje, o MST tornou-se uma organização social complexa, que administra desde estabelecimentos agropecuários, cooperativas, escolas, institutos até

\footnotetext{
9 A coluna Prestes foi um movimento tenentista liderado pelo coronel Luiz Carlos Prestes, de 1925 a 1927 , e percorreu o Brasil em marcha para derrubar a República Velha de Artur Bernardes.
} 
diferentes eventos sociais e políticos, de modo que nossos trabalhos podem ser realizados em uma comunidade assentada, com uma coordenação regional ou estadual, com coordenação de setores, ou ainda com a Confederação das Cooperativas de Reforma Agrária do Brasil - CONCRAB. São diferentes projetos, que são desenvolvidos de acordo com nossas potencialidades. ${ }^{10}$ (FERNANDES et al, .)

\section{A EDUCAÇÃO DO MST}

Vivam por mim, já que eu não posso viver.

A alegria de trabalhar com crianças e adultos,

que com sua luta e com sua esperança

estão conseguindo ser eles mesmos e elas mesmas.

Paulo Freire (1996)*

A educação do MST é a segunda cerca depois do latifúndio, como disse Paulo Freire ao mencionar uma frase de um educador, alfabetizador, sem-terra de um assentamento no Rio Grande do Sul:

Um dia pela força de nosso trabalho e de nossa luta cortamos o arame farpado do latifúndio e entramos nele, mas quando nele chegamos, descobrimos que existem outros arames farpados, como o arame da nossa ignorância, e então ali eu percebi, melhor ainda naquele dia, que quanto mais ignorante, quanto mais inocente diante do mundo, tanto melhor e quanto mais sabido, no sentido de conhecer, tanto mais medrosos ficarão os donos do mundo. ${ }^{11}$ (FREIRE, 1996).

É preciso contextualizar a experiência de quem vive no Movimento para compreender como se dá a formação de um novo sujeito sociocultural. O MST está formando este novo sujeito não só social, como também cultural, seja na forma de realizar sua luta ou na vivência de valores e comportamentos. O Brasil escreve um novo capítulo na sua história a partir da

\footnotetext{
${ }^{10}$ Disponível em: <http:// http://proex.reitoria.unesp.br/congressos/Congressos/1_Congresso/Reforma_ Agr_ria_e_Trabalho_Rural/Trabalho01.htm>. Acesso em: 12 dez. 2007.

${ }^{11}$ Paulo Freire - um educador do povo ANCA/FNDE. São Paulo, ANCA, 2005. p. 40 (Transcrição do depoimento de Paulo Freire gravado em novembro de 1996).

* Idem item 7.
} 
transformação de uma massa de excluídos da terra, desenraizados e isolados em sujeitos socioculturais (CALDART, 2004).

A educação do MST transcende a escola porque ocupa e amplia essa dimensão de espaço físico para uma dimensão sociocultural; social quando o sujeito entra para o movimento e cultural quando assimila um modo de vida diferente, que se forma e se transforma, de trabalhadores isolados e desenraizados em um coletivo, que traz consigo uma herança de valores e objetos compartilhados. Ao se integrar ao movimento, esse sujeito leva consigo o peso histórico, formador e cultural de um povo.

Assim, a instituição escolar tende a ser considerada cada vez mais, tanto pelas famílias quanto pelos próprios alunos, como um engodo, fonte de uma imensa decepção coletiva: essa espécie de terra prometida, semelhante ao horizonte, que recua à medida que se avança em sua direção (BOURDIEU, 2004, p.221).

Portanto, trata-se de compreender a educação do MST a partir de uma pedagogia própria, a Pedagogia do Movimento, construída por meio da cultura que está se formando com este novo sujeito sociocultural, ciente do seu papel histórico e político, modelado como uma amálgama e dá forma às ações do grupo orientadas por uma interpretação marxista da história.

Segundo Ana Mae ${ }^{12}$,

(...) Nas escolas do MST, que em geral são organizadas nas melhores edificações dos assentamentos ou nas melhores tendas nos acampamentos, a foto de Paulo Freire é pendurada com respeito. A despeito do esquecimento ao qual Paulo Freire vem sendo gradativamente condenado no Brasil, os que têm consciência política valorizam suas idéias e sua obra em todo o mundo (...).

O Movimento aponta na direção de uma nova perspectiva de transformação social e questiona o futuro da educação em geral pelas suas práticas e concepções atuais entendidas “como parte de um processo histórico mais longo, amplo e complexo, e como enraizado em uma cultura que projeta um mundo ou um tipo de organização da sociedade que ainda não existe, mas cuja idéia resiste no imaginário de um povo que não sucumbiu ao domínio da ideologia do 'fim da história' e do chamado ‘pensamento único" (CALDART, 2004, p. 42).

12 Ana Mae Barbosa. A arte na educação do MST. Disponível em <http://www.revista.art.br/sitenumero-04/apresentacao.htm>. Acesso em: 30 set. 2006. 


\subsection{Tecendo um olhar sobre o MST}

Para sustentar este olhar sociocultural do MST, Caldart se apóia em três fontes principais: na própria realidade, na história social marxista e nas teorias pedagógicas. A primeira fonte está nas matrizes camponesa e religiosa do homem do campo, que conserva e transmite sua cultura oral entre gerações junto com a cultura de lutas históricas do campesinato, enquanto um setor da Igreja, ao fazer sua opção pelos pobres, criou a Comissão Pastoral da Terra, inspirada no pensamento renovador da Teoria da Libertação, e encorajou este novo homem a tornar-se um lutador social do campo. Este fato provoca um estranhamento sobre a imagem ingênua e oprimida do homem do campo, que agora se levanta para tornar-se sujeito da sua própria história, incomodando as velhas estruturas. Como diz Milton Santos,

os sem-terra falam por nós. Eles nos representam. Nós não podemos protestar porque temos medo de perder o emprego, de experimentar nossas idéias. Preferimos navegar em projetos apenas pessoais e quando aparece o MST protestando nós ficamos felizes, todos (OESP, 19/01/97 apud CALDART 2004 P.50).

O MST começa a ser visto como criador de uma alternativa cultural, alternativa à desumanização, degradação moral e individualização provocada pela indústria cultural e pelo capitalismo (idem, p. 48).

Este homem, invisível para a história, está escrevendo uma história capaz de "virar o mundo de ponta cabeça”, subvertendo a ordem. Trata-se da segunda fonte baseada na tradição teórica dos estudos da história social marxista, como fizeram os historiadores Thompsom, Hobsbawm, Rudé ou Hill ${ }^{13}$, em que é preciso olhar para os movimentos populares e compreender a história de baixo para cima, como no poema de Brecht, ao perguntar: "quem

13 Esses autores, citados tanto na obra de Caldart como de Berger, são referências para mostrar como a história pode ser contada de outra forma, a partir de pessoas comuns, operários e camponeses. 
construiu Tebas dos Sete Portões?"14, ou seja, "o mundo virado de ponta cabeça."15 Imagine a história do Brasil sendo escrita por pessoas comuns, pelos movimentos populares, pelos pobres do campo (ibdem, p.62-65).

A terceira fonte refere-se à teoria pedagógica, na qual a educação é mais do que escola; a escola é apenas parte de um processo educativo mais amplo, provocado pela própria dinâmica do movimento. Uma pedagogia centrada não na escola, e sim nas relações entre a educação e a vida produtiva, que dê sentido ao aprendizado como experiência vivida e aprendida e inserida na dinâmica social. Outro aspecto está em recuperar a educação como formação humana, cujo papel da escola é ajudar no processo social em que se estabelecem as relações entre educação e vida produtiva, formação humana e cultura e entre educação e história. São estes conceitos que devem nortear a escola para criar vínculos com os processos sociais concretos.

A formação dos sem-terra como processo educativo implica uma discussão pedagógica que extrapola a educação escolar. Arroyo ${ }^{16}$ coloca como matrizes pedagógicas, para uma dimensão formadora: os processos de trabalho, os movimentos sociais e a dinâmica cultural. Neste sentido, o próprio Movimento se configura como processo educativo mais amplo, pois recupera a

concepção universal de educação, (...) no sentido de universalidade, pluralidade, omnilateralidade das dimensões humanas e humanizadoras a que todo indivíduo tem direito por ser e para ser humano (...) pela igualdade e diversidade, da pedagogia do trabalho como princípio educativo (...),

oposta à concepção propedêutica, transmissiva utilitarista e reducionista de educação para o mercado de trabalho (idem p. 81).

Na educação como formação humana, Paulo Freire, na Pedagogia do Oprimido, considera a invasão cultural como uma ação antidialógica caracterizada pela "penetração que

14 “Quem construiu Tebas, a dos sete portões?/ Nos livros estão os nomes dos reis/ Foram eles, pois que levantaram os blocos de pedra?/ E a Babilônia, tão freqüentemente destruída,/ quem a reconstruiu uma vez e outra vez?/ Em que casas viviam os construtores da Lima reluzente de ouro?/ Onde foram os ladrilhadores na noite em que ficou concluída a Grande Muralha da China?/ A Grande Roma está cheia de arcos do triunfo./ Sobre quem triunfaram os Césares?/ Havia somente palácios para os habitantes da decantada Bizâncio?” O poema segue com mais alguns versos, terminando assim: "Tantos informes/Tantas perguntas". Caldart extraiu este poema do livro História popular y teoria socialista, que tem como editor o historiador Rafael Samuel, que selecionou este poema para mostrar a relação entre o marxismo e a história popular.

15 Expressão utilizada por Chistopher Hill sobre a Revolução Inglesa relata a história através de personagens secundários.

16 O texto de Miguel Arroyo, Trabalho - educação e teoria pedagógica integra o livro organizado por Gaudêncio Frigotto, Educação e crise no trabalho. 
fazem os invasores no contexto cultural dos invadidos, impondo a estes sua visão de mundo, enquanto lhes freiam a criatividade, ao inibirem sua expressão" (FREIRE, 1983, p. 178). O opressor, ao introjetar sua visão de mundo no oprimido, cria uma barreira cultural que o impede de fazer suas próprias escolhas. Uma forma de transcender este bloqueio está em fazer uma "síntese cultural", ou seja, promover a imersão no seu próprio mundo cultural, que é também político, econômico e social, por meio dessa interação pelo diálogo entre as culturas do educando e do educador, como nas palavras do próprio Freire, as pessoas se educam entre si, mediatizadas pelo mundo (idem, p. 88).

\subsection{Educação é mais do que escola no MST}

Rubem Alves ${ }^{17}$ relata sobre uma escola que sempre sonhou, mas que nunca imaginava que existisse, a Escola da Ponte em Portugal, uma escola sem paredes, nem muros, onde as turmas não são organizadas por faixa etária e os alunos se ajudam mutuamente, uma escola onde cada turma é formada por afinidades e os conteúdos são construídos de acordo com as áreas de interesse, onde há uma gestão democrática e participativa.(ALVES , 2001)

Miguel Arroyo, porém, considera que está havendo no Brasil

um movimento de renovação pedagógica com raízes populares e democráticas como nunca houve neste país. É algo completamente novo, diferente, por quê? Porque se insere num movimento social e cultural, brota do próprio movimento social do campo ou dos movimentos sociais da cidade .

Ele cita várias experiências brasileiras da educação do campo e da cidade, como

em Belo Horizonte, a Escola Plural; em Brasília, a Escola Candanga; em Porto Alegre, a Escola Cidadã; e em Blumenau, a Escola Sem Fronteiras. Há uma série de experiências renovadoras coladas às raízes populares, ao movimento da renovação pedagógica, na cidade, nos municípios e também no campo (idem, p. 68).

Ao se referir à educação do MST, Arroyo afirma:

Vocês defendem a alternância entre família, trabalho, escola, ou uma proposta de educação básica como síntese orgânica entre as experiências na vida familiar, produtiva, da rua, do campo, do trabalho e de projetos educativos. A escola é mais um dos lugares onde nos educamos. Os processos educativos acontecem fundamentalmente no movimento social,

17 Convidado a conhecer a Escola da Ponte em Portugal, Rubem Alves, ao retornar, encantado com o que viu, escreveu e publicou crônicas no Correio Popular de Campinas, e em 2001 publicou o livro "A Escola que sempre sonhei sem imaginar que pudesse existir”. Em 2005 chegou à $8^{\text {a }}$ edição. 
nas lutas, no trabalho, na produção, na família, na vivência cotidiana. E a escola, o que tem a fazer? Interpretar esses processos educativos que acontecem fora, fazer uma síntese, organizar esses processos educativos em um projeto pedagógico, organizar o conhecimento, socializar o saber e a cultura historicamente produzidos, dar instrumentos científico-técnicos para interpretar e intervir na realidade, na produção e na sociedade. A escola e os saberes escolares são um direito do homem e da mulher do campo, porém esses saberes escolares têm que estar em sintonia com os saberes, os valores, a cultura e a formação que acontecem fora da escola (idem, p. 77-78).

Em 1989, foram criados a Fundação de Desenvolvimento, Educação e Pesquisa, RS (FUNDEP), uma organização articulada pelos movimentos populares, por setores da Igreja e por um grupo de educadores para elaborar propostas de educação formal, e o Departamento de Educação Rural (DER), voltado para a inclusão dos pequenos produtores rurais nas questões da educação. O MST foi convidado a participar das reuniões e sugeriu a criação do curso supletivo de Magistério para professores de assentamento de todo o Estado. O curso foi o primeiro a ser implantado e estendido a todos professores da rede, professores rurais e dos assentamentos, que trocaram experiências gratificantes sobre o sistema de co-gestão entre alunos, professores, Setor de Educação do MST e representantes dos órgãos municipais de Educação não-formal (CALDART, 2004).

\subsection{A criação de uma proposta pedagógica}

A preocupação com o ensino tradicional que preparasse o educando para continuar seus estudos e as dificuldades de inserir a escola no Movimento dividiram as opiniões, e em 1990 foi elaborada uma proposta pedagógica coletiva do MST para suas escolas a partir de duas questões: "O que queremos com as escolas dos assentamentos e como fazer esta escola que queremos?"

Para elaboração da proposta, adotou-se o método de princípios, uma forma de organizar sem normatizar, de modo a permitir flexibilidade na elaboração do projeto pedagógico. Eram três os princípios básicos: o primeiro era a própria experiência dos educadores nos acampamentos e nos assentamentos; o segundo baseava-se no próprio movimento como formador de um novo sujeito social, do trabalho como princípio educativo do trabalho, pela forma de se organizarem coletivamente e pela importância da mística como celebração popular; e o terceiro, na base teórica de Paulo Freire e dos pedagogos socialistas 
Krupskaya, Pistrak, Makarenko e José Marti, numa relação com as teorias em forma de sínteses livres das suas idéias.

São muitas as demandas de educação, não só como política pública como também como preocupação e prioridade estratégica do Movimento. Da educação infantil ao ensino superior, há sempre um segmento a ser atendido em cada uma das diferentes áreas e níveis do conhecimento. A educação infantil e a alfabetização de adultos são dois extremos da educação que precisam ser atendidos pelo governo, e como não estão sendo, o MST está cumprindo essa lacuna com projetos próprios.

Um novo campo da Educação se estrutura: o da Educação não-formal. Ela aborda processos educativos da sociedade civil, em torno de ações coletivas do chamado terceiro setor da sociedade, abrangendo movimentos sociais, organizações não-governamentais e outras entidades sem fins lucrativos que atuam na área social ou processos educacionais, frutos da articulação das escolas com a comunidade educativa via conselhos, colegiados etc. (GOHN, 1999, p. 7).

Em 1990 foram criadas as Cirandas infantis, para crianças de 3 a 5 anos, uma expressão mais condizente com o conceito de cuidado pedagógico baseado na igualdade, solidariedade, brincadeira e muita alegria, para substituir a expressão "creche", que sugere depósito de crianças.

\subsection{Alfabetização de adultos}

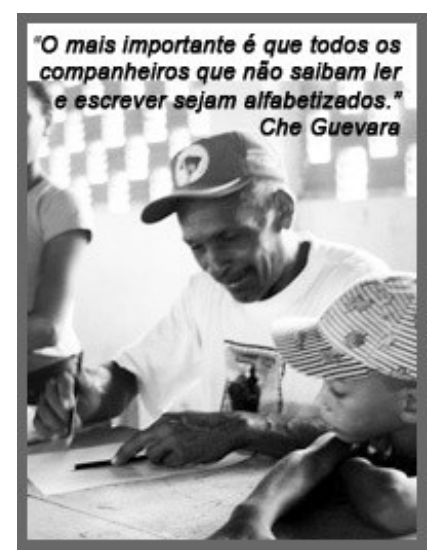

Cartaz da Campanha Nacional de Alfabetização de Adultos do MST - Todos e todas sem-terra estudando (MST, 2007) 
Para atender ao grande número de analfabetos, em 1989 começou a se discutir a necessidade de uma campanha Nacional de Alfabetização nos Assentamentos. A idéia se espalhou por outros Estados, e em 25 de maio de 1991, em Bagé-RS, o Projeto de Alfabetização de Jovens e Adultos dos Assentamentos do MST teve o seu lançamento oficial, com a presença de Paulo Freire, que fez o discurso de abertura dizendo:

Esta tarde é uma das tardes mais bonitas (...) enquanto espírito, enquanto alma (...) porque parte de um processo, de uma caminhada (...) foi preciso que alguns morressem, que alguns desistissem, foi preciso que fortalecessem sua coragem de briga e iluminassem o seu sonho de refazer o mundo para que esta tarde ocorresse (...). Por causa de brigas como estas de vocês, eu passei 16 anos proibido de voltar ao Brasil. Eu fui preso, eu fui expulso da Universidade onde eu trabalhava, eu fui obrigado a deixar o país, precisamente porque eu acreditava que era preciso e possível ver tardes como estas (...).

Segunda-feira eu me despeço da Secretaria de Educação de São Paulo e não poderia haver coisa mais gostosa do que falar como secretário de uma grade cidade como São Paulo a vocês. Esta seria a melhor maneira que eu teria de encerrar a minha atividade fora de São Paulo, era falando ao Brasil. (...) esta tarde marca o começo mais sistematizado de um novo processo ou de um desdobramento do primeiro, de um grande processo de luta, que é um processo político, que é um processo social e que também é um processo pedagógico. (...) tem a ver com dois direitos fundamentais que poucos têm e pelos quais devemos brigar. $\mathrm{O}$ direito a conhecer, conhecer o que já se conhece e o direito a conhecer o que ainda não se conhece. $\mathrm{O}$ que eu quero dizer com isto? Em primeiro lugar, conhecer melhor o que já se conhece tem que ver com o que a gente chama de saber popular, sabedoria popular, ao lado do saber que a gente chama de saber erudito que a canção cantada aqui se referia à caneta e à enxada. (...) O direito de saber melhor o que já se sabe significa ultrapassar os níveis de conhecimento que tenho hoje sobre o mundo (...).

Há certos acadêmicos que desprezam o saber popular, são reacionários, ou seja, ignorantes inocentes. (...) A prática sozinha sem teoria termina por não saber a si mesma. Termina por provocar a perda de endereços dos que praticam. A teoria sozinha sem a incursão até o concreto se perde numa coisa que a gente chama de blá, blá, blá,... É preciso que juntemos as duas coisas constantemente. Não há prática sem teoria e não há teoria que não se submeta ao ajuizamento da prática”. Termina com um apelo: “(...) que este assentamento se fortaleça como produtor de cultura, como produtor de liberdade, como produtor de democracia, como produtor de saber". (ANCA, 2005, p. 25).

O legado de Paulo Freire de alfabetização de adultos foi assumido pelo MST como uma luta tão importante como a da terra e pela reforma agrária, e já alfabetizou milhares de pessoas nas escolas do MST.

O Movimento Nacional de Educação de Jovens e Adultos já realizou muitos projetos, e em 2005 lançou o método de alfabetização Sim, Eu Posso!, em parceria com o Instituto 
Pedagógico Latino Americano e Caribenho de Cuba (IPLAC) ${ }^{18}$, e está sendo implantado por educadores (leigos) do próprio Movimento como forma de incentivar a volta à escola de pessoas das famílias do MST com o perfil de idade acima de 50 anos.

\subsection{A formação de professores}

A necessidade detectada inicialmente com a formação de professores levou o Setor de Educação a criar o curso de Magistério do MST, em 1989, no Rio Grande do Sul, que se espalhou por vários Estados e já tem várias turmas formadas. Em 1998, numa parceria com a Universidade de Ijuí, foi criado o primeiro Curso Superior de Pedagogia.

Em 1997, o MST em parceria com a UNB, UNICEF, UNESCO e CNBB, realizou o I Encontro Nacional de Educadores e Educadoras da Reforma Agrária (ENERA). Este encontro resultou na criação do Pronera, Programa Nacional de Educação na Reforma Agrária, com o objetivo de ampliar os níveis de escolarização formal dos trabalhadores e trabalhadoras assentados da reforma agrária, com projetos educacionais e metodologias específicas para o campo. (KOLLING, CERIOLI , CALDART, 2002)

O Pronera se propõe a garantir a alfabetização e educação fundamental de jovens e adultos acampados (as) e, ou, assentados (as) nas áreas de reforma agrária, formação de educadores (as) para atuar na promoção da educação, formação continuada no ensino médio e superior e formação técnico-profissional de nível médio e superior para diversas áreas do conhecimento. Também estão dentro das atividades desenvolvidas pelo Programa materiais didático-pedagógicos, seminários, encontros, estudos e pesquisas de âmbito regional, nacional e internacional. (MST, 2005)

Graças ao Pronera, muitas parcerias com universidades de todo o País estão realizando convênios para formação não só de educadores do campo para o ensino fundamental II, como também de todas as áreas, como médicos, agrônomos, advogados, pelo regime de alternância, previsto na Constituição. Os candidatos às vagas são indicados pelo seu coletivo e devem preencher os pré-requisitos legais, como ter concluído o ensino médio e prestar vestibular, específico para o curso cujas vagas são exclusivas aos trabalhadores do campo, mas não exclusivas do MST, e sim ao conjunto de organizações e sindicatos de trabalhadores rurais.

18 O projeto de alfabetização do IPLAC recebeu o Prêmio de Alfabetização 2006 Rey Sejong da UNESCO, e está sendo aplicado em 19 países da América Latina, do Caribe, da África e da Oceania, onde foi adaptado aos contextos sociais, culturais e étnicos das diversas regiões especialmente às mulheres. Disponível em: http:/www.granma.cu/portugues/2006/noviembre/lun6/46entrega-p.html acesso em 18 set. 2007. 
Concorrem à vaga candidatos de todo o País, e uma vez aprovados ficam alojados na universidade durante o curso, em regime presencial, sendo dois meses na universidade e dois meses em casa, ou em julho e de novembro a fevereiro, de acordo com o calendário escolar.

Hoje o Pronera é uma política do governo federal, executada pelo Incra e pelo Ministério do Desenvolvimento Agrário (MDA), um relevante instrumento de democratização do conhecimento no campo, ao propor e apoiar projetos de escolarização formal em todos os níveis de ensino. O Pronera trouxe importantes avanços nas políticas de educação no campo, para atender às necessidades e aos interesses específicos de quem vive no campo. Com o Pronera, o debate avançou e foram retomadas antigas reivindicações, que contribuíram para o resgate da auto-estima e dos vínculos com o campo, um espaço que é ao mesmo tempo produto e produtor de cultura, e não somente de produção econômica.

\subsection{As matrizes pedagógicas do movimento}

Desse processo de formação humana, segundo Caldart, consolidou-se a Pedagogia do Movimento Sem-Terra, um projeto pedagógico formado por cinco matrizes pedagógicas básicas na formação do sujeito sociocultural: pedagogia da luta social, pedagogia da organização coletiva, pedagogia da história, pedagogia da terra e pedagogia da cultura, e é a partir desta última pedagogia que o trabalho será desenvolvido.

\subsection{A pedagogia da cultura}

A pedagogia da cultura, ou "como os Sem-Terra se educam cultivando um modo de vida produzido pelo movimento" (CALDART, 2004, p. 361). Os sem-terra estão criando uma cultura própria, pelo jeito como se organizam, nos 'causos' que celebram as conversas, nos gestos, na arte, na música e poesia que nasce no interior do MST, nas canções infantis, no teatro, nas pinturas e nos murais, na mística, na religiosidade e nos hábitos que resgatam a vida no campo, devolvendo-lhes as memórias da infância com uma vivência de luta coletiva.

Uma cultura que começa a nascer desde o primeiro momento, quando a família é aceita pelo coletivo, depois no acampamento, nos encontros e cursos de formação, nas assembléias ou nas marchas, criando um sentimento de pertença no mundo onde tudo faz sentido, mesmo que isto lhe custe muito sacrifício. Tudo vale a pena porque não estão sozinhos, sua luta não é solitária, pois os vínculos transcendem o sonho da luta pela terra e 
permeia outras dimensões do ser, sentindo-se fortalecidos e protegidos, preenchidos por uma felicidade que é mais espiritual. A evidência desta cultura se manifesta de várias formas, quando lhes perguntam quem são e a resposta é "somos sem-terra do MST". Esta fala tem um sentido muito maior do que uma identidade; está carregada de histórias e vínculos profundos que foram marcando a personalidade de cada militante (CALDART, 2004, p. 361).

A arte dos sem-terra, segundo Bogo ${ }^{19}$, "vai além das belas artes, ligam à vida e à utopia socialista. A educação artística sai de dentro das escolas porque os antigos espectadores se transformaram em “artistas” da própria história” (BOGO, 2002, p. 144).

Cantadores, poetas e artistas expressam seus sentimentos de várias formas - poesia, música, mímica, pintura, cartazes, gestos ou símbolos da arte em geral, carregados de significados e sentimentos. Por meio da arte esses artistas se revigoram para continuar na luta e ajudam a fortalecer os vínculos entre os militantes. Sua origem está na cultura popular e os artistas aprendem a compor e tocar instrumentos, a compor poesias e músicas e a produzir artes visuais por meio do conhecimento adquirido, em geral pela cultura oral, desenvolvendo seu próprio talento para se expressar em diversas linguagens. Encontram inspiração para suas composições nas questões da terra, na sua trajetória e no cotidiano do próprio Movimento, uma vida marcada pelas ocupações e desocupações, por assassinatos no campo, crimes ambientais e reforma agrária. As músicas denunciam as mortes de seus companheiros e a parcialidade da justiça, em geral a favor das empresas transnacionais e dos latifúndios dos quais muitos são os próprios proprietários.

Como afirma Francastel,

a arte é um instrumento de propaganda tanto nas mãos dos fracos como dos poderosos. Ela não desempenha um papel apenas na ação política de um Péricles, de um Luís XIV, de um Urbano VIII ou de um Hitler. O artista dá forma aos objetos e às idéias (...) testemunhos mais diretos e amiúde os mais secretos, das grandes formas de sensibilidade coletiva. Vemos assim o imenso alcance histórico e sociológico do testemunho da arte. Longe de nos fornecer indicações apenas sobre a vida das classes dominantes e nos revelar apenas palavras de ordem oficiais, ela é, ao contrário, um dos testemunhos que traem os instintos profundos da massa anônima, os conflitos de crenças ou de interesses da multidão com seus mestres (FRANCASTEL, 1993, p. 29).

19 Ademar Bogo é militante do MST, ex-seminarista, atua no Setor de Formação do Movimento; poeta e escritor, autor do Hino do MST e de vários livros e músicas sobre a cultura, educação, música e a mística do Movimento. 
A arte não tem fronteiras, não tem preconceitos não tem limite de idade ou qualquer restrição social ou cultural, a arte é a expressão autêntica do ser humano em todas as fases de sua vida.

A motivação para desenvolver esse 'talento' pode ser atribuída, em grande parte, a um momento muito importante que ocorre em todos encontros, cursos, assembléias, seminários e congressos; um momento reservado para apresentação de um ato simbólico relacionado ao tema do encontro, preparado previamente por um grupo de participantes designados para apresentação; a mística, de influência religiosa ${ }^{20}$, é uma celebração, uma forma livre e espontânea de representação, em que todos são incentivados a participar, e, assim, até as pessoas mais tímidas que não acreditam no seu potencial, ao se expressarem, adquirem autoconfiança e aumentam sua auto-estima. Como relata D. Tomás Balduíno,

a mística tem um móvel libertador, é como uma mola. Eles têm algo de próprio e logo sentiram que eles não eram uma comunidade de base, que eles não eram uma confraria, eles não eram membros de uma paróquia, ou seita... são do MST. Isto é muito esclarecedor para situar o MST numa trajetória humana. Não é criação deles, eles entram numa corrente. Eu acho que eles são sucessores, uns dignos sucessores de Ajuricaba, Zumbi, Antonio Conselheiro ${ }^{21}$.

Como diz Arroyo,

aqui se fala mais com gestos do que com palavras. Isto é uma característica muito forte do movimento social do campo. Vocês falam de mil maneiras, falam com muitas linguagens, com palavras, rituais e com sua mística maravilhosa. Falam cantando, falam com a presença das crianças (...). Mas o que mais me impressionou são os rituais, os gestos. A força educativa do ritual, dos gestos (...) gestos que impressionam, chocantes, que obrigam a pensar e repensar este país. (ARROYO, CALDART, MOLINA, 2004 ,p. $67)$.

O homem do campo é um ser místico por natureza, ele não tem tempo e olhos só para a terra. Sua relação direta com a natureza permite um olhar mais sensível e atento ao ritmo da natureza e com ela acerta o compasso da vida e cria uma relação de respeito aos seus sentimentos e a expressão artística flui em diferentes linguagens, como na música, no teatro, nas artes visuais e na dança. Em todas as manifestações, pode-se notar a influência da sua origem camponesa e religiosa, porém com forte conteúdo político, que revela a força da união, do sentido coletivo, a consciência de que são lutadores e estão nessa caminhada por um

\footnotetext{
${ }^{20}$ A mística nasceu e se desenvolveu no Movimento através da CPT - Comissão Pastoral Terra.

${ }^{21}$ Depoimento colhido no vídeo Terra, Mística Vida!, realizado por Mário Henrique e Vasconcelos Neto.. Disponível em: < http://www.youtube.com/watch?v=toitTQNcbJk>. Acesso em: 15 dez. 2007.
} 
objetivo muito claro, a reforma agrária, e através da sua arte, deixa sua marca registrada na história do MST.

A mística é, na definição de Fernandes, "uma forma de linguagem dos iletrados que constroem suas expressões, se comunicam e se interagem na construção da consciência da luta pela terra" (FERNANDES, apud VIEIRA, 2003) 22. A apresentação de uma mística representa um grande laboratório de produção de artística, e mesmo que um integrante do grupo nunca tenha participado, na primeira oportunidade, ao ser iniciado, se coloca por inteiro em uma performance, dando o melhor de si, vivendo por inteiro sua representação, e apesar de ter se preparado, com ensaios, sua apresentação será um momento único na sua vida, marcando sua iniciação diante do público, que saberá respeitar suas limitações e o incentivará a progredir cada vez mais.

O sentido da mística para o MST é muito mais amplo, mais do que uma simples celebração, sua importância está, segundo Boff, na

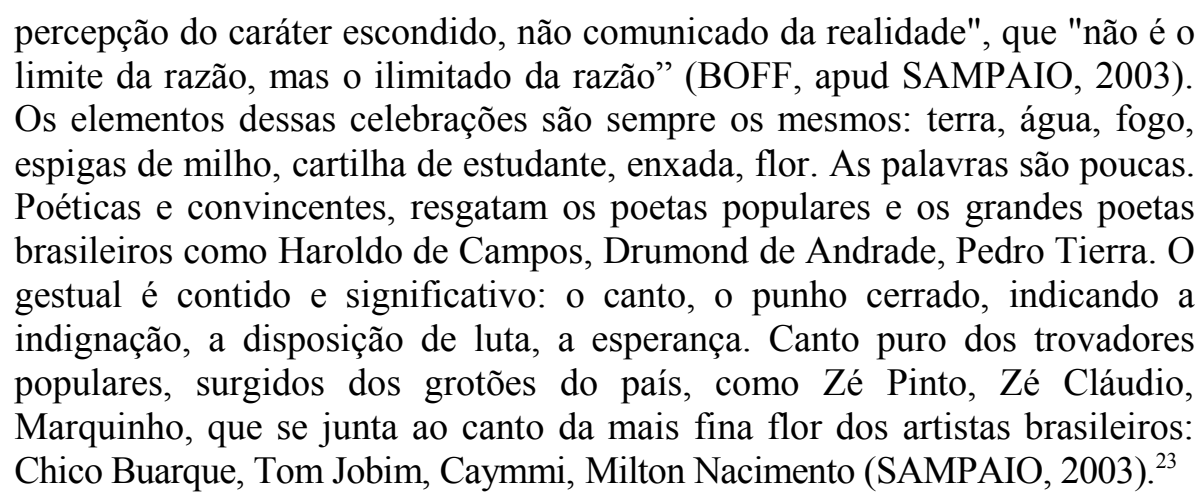

A mística é uma via de mão dupla, enquanto eleva a auto-estima, incentiva a ousar e avançar, está presente na representação de sentimentos e sonhos, na fantasia, na utopia, nos ideais que almejamos alcançar.

A música produzida pelos artistas do Movimento é muito importante e, em geral, é transmitida oralmente, embora eles tenham CDs gravados, muitas músicas não-gravadas são conhecidas e cantadas por eles. A cultura popular, como as danças e as festas, está presente nos acampamentos e assentamentos. É como se dentro do Movimento eles tivessem permissão para fazer o que não teriam coragem de fazer fora.

\footnotetext{
22 Fernandes, Bernardo Mançano. Pequeno vocabulário da luta pela terra. Disponível em: $<$ http://www.landless-voices.org/vieira/archive-05.phtml? $\mathrm{rd}=$ PERFMYST001\&ng $=\mathrm{p} \& \mathrm{sc}=2 \&$ th $=17 \& \mathrm{se}=0>$. Acesso em 12 jun.2006.

23 Sampaio, Plínio de Arruda. A mística. disponível em http://www.landless-voices.org/vieira/archive-05.phtml? $\mathrm{rd}=$ MSTICAOF657\&ng $=\mathrm{p} \& \mathrm{sc}=3 \& \mathrm{th}=42 \& \mathrm{se}=0>$. Acesso em $: 12$ jun. 2006.
} 
A música é uma das principais linguagens artísticas do MST. É cantada nas místicas e nas marchas, nas escolas e nos encontros, nas rádios e nos bailes; a música está presente em quase todos os eventos e fala da luta pela reforma agrária, de justiça social e exclusão, ecologia e paz. No início do movimento, muitas músicas não foram registradas ou eram gravações domésticas e se perderam no tempo. O MST já lançou sete CDs: “Arte em Movimento", "Canções que Abraçam Sonhos", "Uma Prosa sobre Nós”, "Um Canto pela Paz", "Cantares da Educação", "Marcial Congo" e o CD infantil "Plantando Cirandas". São canções de artistas do Movimento. ${ }^{24}$ Os artistas mais conhecidos entre os sem-terra são Ademar Bogo, Zé Pinto, Pedro Tierra, Aracy Cachoeira e Ana Cláudia.

As artes visuais são importantes meios de expressão e refletem temas que retratam o simbolismo representado nas marchas, na luta pela terra, nas ferramentas, nas barracas de lona, nas cercas e nos chapéus; objetos e símbolos que incorporam o imaginário se compõem de várias formas. Podemos observar dois importantes grupos de artes visuais. O primeiro reúne as pinturas, esculturas, gravuras de artistas individuais, em geral anônimos, por não se ter registros da autoria das obras. Em muitas obras constam apenas o primeiro nome ou as iniciais, reflexo da cultura popular que está na origem do movimento, onde não havia a preocupação de registrar e documentar seu acervo.

O segundo grupo de artes visuais são os murais, grandes painéis elaborados por equipes para celebrar um encontro, congresso ou festival. Simbolizam o tema do encontro de forma didática, em uma alegoria sobre as questões que serão abordadas no evento. Segundo Mc $\mathrm{Nee}^{25}$, a realização dos murais é "coordenada por artistas experientes de organizações como o Movimento de Artistas da Caminhada, trabalhando por solidariedade com os ativistas do MST, os murais são concebidos e pintados coletivamente”.

\footnotetext{
${ }^{24}$ O resgate deste material foi feito por Else P. Vieira, pesquisadora sênior em línguas modernas da Universidade de Notthighan, que coletou as composições, as produções artísticas, as fotografias, os ensaios, os estudos e os depoimentos de artistas e pesquisadores do MST. Disponível em <http://www.landlessvoices.org/vieira $>$. Acesso em: 20 abr. 2005. 


\title{
3. A ARTE-EDUCAÇÃO DO MST
}

\author{
Era uma casa muito engraçada \\ Era de lona e não de tábua \\ Esta casinha chama barraco \\ Quem mora nela é quem não tem terra
}

Rosane, 14 anos, Rio Grande do Sul.

O ensino da arte está na raiz do Movimento, presente na pedagogia da cultura do Movimento, que aprendeu com Paulo Freire a importância da arte na formação de uma consciência crítica do sujeito, como afirma: "a necessária promoção da ingenuidade à criticidade não pode ou não deve ser feita à distância de uma rigorosa formação ética ao lado sempre da estética" (FREIRE, 1996, p. 32).

Na década de 1960 Paulo Freire implantou seu método de alfabetização de adultos e criou também os Centros de Cultura Popular. No mesmo espaço onde aconteciam as aulas de alfabetização, também se promoviam eventos culturais como afirma Scocuglia (2001, p. 51), "certamente, uma das formas de "estar no Estado", transcendendo-o, foi impulsionada pela priorização da educação como cultura e da cultura como manifestação artístico cultural" e "ficou evidente a influência das propostas político-pedagógicas de Paulo Freire" (idem, p. 55) em outros movimentos de alfabetização.

Sobre o ensino da arte no MST e Paulo Freire, Ana Mae deixa um importante relato:

Penso que os namoros do MST com a Arte têm não só a influência de Sebastião Salgado, mas também de Paulo Freire. O grupo de Artes era o maior dentre a equipe de Reorientação Curricular de Paulo Freire e seu projeto educacional foi o que no Brasil mais espaço deu à Arte.

Ainda em 1995, líderes do assentamento de João Câmara no Rio Grande do Norte procuraram a Escolinha de Arte Newton Navarro, em Natal, pedindo professores para implementarem com eles um programa de Arte na sua escola. A Escolinha de Arte Newton Navarro é uma das poucas remanescentes do Movimento Escolinhas de Arte de Augusto Rodrigues, que chegou a ter 132 unidades no Brasil e uma no Paraguai, criada por Lívio Abramo.

Wandecí de Oliveira Holanda comandou a equipe de professores que, dialogando com os líderes do assentamento, levantou as necessidades do grupo de adolescentes e crianças com o qual iam trabalhar. Perguntei a ela $o$ que os pais esperavam do ensino da Arte. Ela me contou que uma das mães lhe dissera: - 'Eu sei que Arte é coisa de rico, mas eu quero para meu filho'. 
A cidade de João Câmara tem um dos menores índices de desenvolvimento humano do Brasil. Apesar disto, o trabalho foi muito bem-sucedido. Fizeram teatro com Lenilton Teixeira e Edson Moura, dois dos melhores professores de teatro do Brasil. Todos costuravam, meninos, meninas, mães e professores, para fazerem os figurinos das peças, aproveitando roupas velhas. O professor de música trabalhou com um sanfoneiro do assentamento e usaram o sistema de autofalantes destinado à informação sobre os problemas comuns, desta vez para divertir a todos. Os professores de Artes Visuais os ensinaram a reciclar papel através de um projeto interligando Arte e Ecologia. (Barbosa, 2005).

Em 1998, na Conferência Nacional, o Setor de Educação do MST apresentou a proposta de realizar o Concurso Nacional de Redações e Desenhos para Estudantes do MST, com o objetivo de sensibilizar e dialogar com seus militantes os temas pertinentes ao Movimento. O título apresentava-se restritivo quanto às formas de expressão, pois a expressão 'desenho' não representa o universo de possibilidades das artes visuais, o desenho é apenas uma forma de expressão. Da mesma forma, a expressão 'redação' limita o campo da linguagem literária e exclui, entre outros, o gênero poesia, que poderia ser bem explorado pelos estudantes. Seria um engano pensar que estudantes são somente as crianças em idade escolar, sem considerar o grande contingente de analfabetos do meio rural que estão sendo alfabetizados nos cursos de EJA.

O concurso incentiva a participação como forma de integração e inserção social. A importância desta iniciativa está no diálogo direto com a militância, que responde às questões emergentes apontadas pelos temas do concurso; não se trata apenas de descobrir novos talentos ou os melhores trabalhos com a utilização de técnicas especiais, mas sim fazer um diagnóstico e formar um acervo artístico e histórico do MST.

Em setembro de 2006, o MST lançou o $6^{\circ}$ Concurso Nacional de Arte-Educação do MST, com o tema: "Como fazer a escola transformando a história". Esta é a primeira vez que o concurso utiliza a expressão "arte-educação" no título e é nesta edição que o Setor de Educação e o Coletivo de Cultura assumem a intenção de "elaborar um método de arteeducação voltado para as necessidades do movimento e afinado com o objetivo de formação de seres humanos emancipados" (MST, 2006, p. 25). A realização do concurso trará subsídios para a pesquisa e avaliação de uma metodologia dialógica com as bases.

Esse concurso servirá de subsídio para a construção coletiva de um método de arteeducação do MST. A partir da base de seus militantes deverá sair os referenciais teóricos e as diretrizes que irão nortear a prática dessa metodologia. É certo que há um caminho já 
percorrido nos cinco concursos anteriores, e pela experiência acumulada em educação e cultura não será difícil construir esse método. Em nenhum momento a 'arte-educação' recebeu tanta atenção e cuidado como agora no lançamento deste concurso. A expressão "concurso" foi empregada no sentido de encontro, cooperação e ajuda, e ao contrário do que se imagina não tem a intenção de promover uma competição ou exaltar talentos individuais, porque não haverá premiação em espécie para os melhores; o regulamento do concurso deixa claro o objetivo pedagógico de construção coletiva e espera-se contar com a participação do maior número de pessoas.

Nesta edição, o concurso substituiu as expressões redação e desenho por literatura e artes visuais, abrindo novas formas de expressão artística. Os trabalhos poderão ser individuais ou em grupo, e a mesma pessoa poderá participar individualmente e em grupo. $\mathrm{O}$ tema questiona a escola e busca na arte-educação uma estratégia para encontrar respostas junto às bases de seus militantes, uma forma de dialogar com todo o Brasil e em todos os segmentos para tirar da própria base uma proposta para o ensino da arte. Os concursos anteriores eram dirigidos aos estudantes do MST, nesta edição a expressão foi suprimida para abrir à participação de todos e não limitar à idéia de que estudante é somente criança.

Para divulgação do concurso foi organizado e distribuído um material elaborado pelo Setor de Educação e o Coletivo de Cultura. O material de divulgação do concurso está dividido em três partes. A primeira traz o regulamento do concurso; a segunda apresenta três etapas preparatórias do concurso, contendo uma pauta e materiais para cada encontro, como contos, poesias e charges para serem analisadas e discutidas nos assentamentos; e a terceira contém textos que servem de subsídios para os educadores. Este caderno visa unificar a comunicação e subsidiar os educadores para que todos tenham clareza dos objetivos e da importância deste concurso para a arte-educação do MST.

Não se trata de um manual que define regras para se trabalhar a arte-educação na sala de aula, uma prática comum nos sistemas de educação, tão combatido por Ana Mae; para ela,

o ensino da arte não deve limitar-se a manuais e fórmulas prontas, deve ao contrário flexibilizar todas as possibilidades e o educador deve ter a liberdade articular e transitar pelos conteúdos, adequando-os a cada situação de acordo com a necessidade do seu grupo. A arte erudita e a cultura popular podem e devem ser contempladas igualmente no espaço educativo. ${ }^{26}$

\footnotetext{
${ }^{26}$ Palavras de Ana Mae proferidas no Encontro de arte-educadores em out/2007, no MASP.
} 


\section{CAPÍTULO II - O ENSINO DA ARTE}

\section{O ENSINO DA ARTE NO BRASIL E A PROPOSTA TRIANGULAR}

O ensino da arte no Brasil, até a década de 1980, por influência do Modernismo, caracterizava-se pela auto-expressão, criatividade e autodescoberta, a ênfase no desenho livre para não interferir na emoção, espontaneidade e criatividade da criança. A partir de 1982, um grupo de pesquisadores ingleses e norte-americanos ligados ao Getty Center for Education in Arts, como Eliott Eisner, Marjorie Wilson, Brent Wilson e Ralf Smith, sistematizou uma proposta concebida na década de 1960 sobre a aprendizagem conhecida como DisciplineBased Art Education - DBAE. Este sistema valorizava os aspectos cognitivos do conhecimento associados ao fazer artístico, incluindo a Crítica de Arte, Estética e História da Arte (RIZZI, 2001 p. 65-6). Dessa forma, a arte se constituía como área do conhecimento, assim como as ciências exatas e humanas.

Na década de 1990, Ana Mae Barbosa sistematizou um método que vinha sendo pesquisado desde 1983, no Festival de Inverno de Campos do Jordão, São Paulo, e no Museu de Arte Contemporânea, adequando-o à realidade brasileira. Segundo Barbosa ${ }^{27}$, "no Brasil a idéia de antropofagia cultural nos fez analisar vários sistemas e re-sistematizar o nosso que é baseado não em disciplinas, mas em ações; fazer-ler-contextualizar” (BARBOSA, 2003). A "Proposta Triangular do Ensino da Arte" foi implantada na rede municipal no governo de Luiza Erundina, na gestão de Paulo Freire/Cortela como Secretários da Educação do Minicípio de São Paulo. Esta proposta amplia e articula o ensino da arte em três ações básicas, como explica a autora: "a Proposta Triangular e o DBAE são interpretações diferentes no máximo paralelas do Pós-Modernismo na Arte-Educação. Trata-se de uma proposta flexível, pois não segue rigorosamente esta ordem e se articulam aos objetivos e aos métodos de trabalho do professor" (idem). Segundo Penna ${ }^{28}$, "a Proposta Triangular representa a tendência de resgate dos conteúdos específicos da área, na medida em que apresenta, como base para a ação pedagógica, três ações mental e sensorialmente básicas que dizem respeito ao modo como se processa o conhecimento em arte".

\footnotetext{
27 Ana Mae Barbosa. Arte Educação no Brasil: do modernismo ao pós-modernismo. Revista Digital Art, n. 0, outubro de 2003. Disponível em <http://www.revista.art.br/site-numero-00/anamae.htm>. Acesso em: $20 \mathrm{dez}$ 2007).

28 Maura Penna. PCN nas escolas: e agora? Artigo disponível em: <http://www.artenaescola.org.br/ /pesquise_artigos_texto.php?id_m=12>.Acesso em: $20 \mathrm{dez} .2007$.
} 
A arte como área do conhecimento representa uma conquista para o ensino da arte, a revisão de uma distorção sobre o ensino da arte no Brasil em considerar arte uma área complementar às demais disciplinas, como afirma Ana Mae:

como a matemática, a história e as ciências, a arte tem domínio, uma linguagem e uma história. Constitui-se, portanto, num campo de estudos específicos e não apenas em meia atividade [...]. A arte-educação é epistemologia da arte e, portanto, é a investigação dos modos como se aprende arte na escola de $1^{\circ}$ grau, $2^{\circ}$ grau, na universidade e na intimidade dos ateliers. Talvez seja necessário para vencer o preconceito, sacrificarmos a própria expressão arte-educação que serviu para identificar uma posição e vanguarda do ensino da arte contra o oficialismo da educação artística dos anos setenta e oitenta. Eliminemos a designação arte-educação e passemos a falar diretamente de ensino da arte e aprendizagem da arte sem eufemismos, ensino que tem de ser conceitualmente revisto na escola fundamental, nas universidades, nas escolas profissionalizantes, nos museus, nos centros culturais a ser previsto nos projetos de politécnica que se anunciam (BARBOSA, 1991, p. 6-7)

Fazer arte corresponde à produção artística, mas uma produção articulada com as duas outras áreas, como produto de um repertório adquirido e desenvolvido mediante a leitura de obras de arte e a contextualização histórica, é um fazer artístico significativo, associado à aquisição de conhecimento adquirido por meio das obras do patrimônio cultural da humanidade.

Regina Machado ${ }^{29}$ sintetiza o ato de criar:

a arte tem seu próprio conteúdo que pode ser aprendido através da manipulação expressiva dos elementos que constituem cada linguagem artística. Jogando tinta no papel, estou me liberando emocionalmente, mas não estou expressando plasticamente. Para expressar-me é preciso perceber, sentir e pensar os dados da minha experiência: materiais, espaço, cores, formas, sons, movimentos, corpo, voz, idéias, acontecimentos, pessoas. É preciso sentir, pensar significações e organizá-las numa forma coerente. É preciso reconhecer meus limites reais para poder ultrapassá-los. É preciso descobrir a importância do ato de criação como parte de minha vida, como forma de conhecimento (Barbosa, 1988, p.90).

Portanto, arte não é somente uma área do conhecimento como transcende a dimensão do fazer para uma consciência do ser pleno entre a razão e a emoção.

Ler obras de arte refere-se ao desenvolvimento cognitivo do educando em relação ao objeto de estudo no contexto histórico da obra, é conhecer a estrutura da obra, seus elementos formais, como cor, linha, forma, plano, textura; os elementos estéticos como harmonia,

29 Relato de Regina Machado publicado no livro Arte-Educação: Conflitos/acertos de Ana Mae Barbosa. São Paulo, Max Limonard, 1988, p. 90. 
equilíbrio, ritmo, movimento e crítica de arte, ao observar o gênero, o estilo e a técnica da obra-de-arte. Segundo Rizzi, "a leitura de obra-de-arte envolve o questionamento, a busca, a descoberta e o despertar da capacidade crítica dos alunos. (...) jugados por critérios tais como: pertinência, coerência, possibilidade esclarecimento, abrangência, entre outros" (idem p. 67). Ana Mae, contudo adverte que "é importantíssimo ressaltar que o objeto de interpretação é a obra e não o artista, não justificando processos advinhatórios na tentativa de descobrir as 'intenções do artista'” (BARBOSA, apud RIZZI, p. 67).

Segundo Pillar (2002, p.73), Agnes Heller diz que "o homem da cotidianidade é atuante e fruidor, ativo e receptivo, mas não tem nem tempo nem possibilidade de absorver inteiramente em nenhum desses aspectos; por isso, não pode aguçá-los em toda sua intensidade". Também o educando, condicionado a ver imagens na velocidade da mídia, poderá descartá-la logo em seguida, após o primeiro contato, mas somente a escola pode proporcionar um momento especial, uma pausa, deixar de lado a agitação da sociedade moderna e expandir o tempo, descompactar, desconstruir cada fragmento do tempo comprimido em frações de segundos e deixar a imaginação solta, livre, um tempo necessário para descongestionar do bombardeio de imagens à qual somos expostos diariamente, que banaliza o mais belo e o mais trágico, nivelando-os num mesmo patamar. Assim afirma Ana Mae (BARBOSA, 1991, p. 10): “O que a arte na escola principalmente pretende é formar o conhecedor, fruidor e decodificador da obra-de-arte (...). A escola seria a instituição pública que pode tornar o acesso à arte possível para a vasta maioria dos estudantes em nossa nação (...)".

A leitura de uma obra-de-arte deve acontecer num clima de prazer, como explica Coli,

as artes oferecem uma possibilidade de conhecimento que não passa por um sistema racional, pela reflexão diretamente, que não passa pelo conceito e que é, antes de qualquer coisa, uma relação intuitiva. Os conceitos, a reflexão e o discurso virão depois. O primeiro dado é o contato com a obra, que gera uma série de informações e reações que, ao mesmo tempo, se encontram associadas ao prazer. (COLI, 2000, p. 6-9).

Contextualizar é a etapa em que o educando articula a obra com a História da Arte e dialoga com as outras áreas do conhecimento, numa relação interdisciplinar, criando-se um campo de significações e relações multiculturais com o ambiente natural, social, científico, cultural, político e ambiental. A articulação do conhecimento com as demais áreas permite ao educando ampliar sua visão de mundo e compreender como as disciplinas se relacionam e de forma integrada. 
Segundo Parsons (1998, p. 8),

a visão contemporânea oferece a oportunidade para integrar a arte com outras disciplinas escolares de modo importante. Esta maneira não reduz a arte a um instrumento para ilustração ou suporte para outros conteúdos: ao invés disso, essas outras matérias torna-se suporte para a arte porque eleas providenciam o contexto necessário para a interpretação.

Para o autor,

nossas metas deveriam incluir a flexibilidade mental que capacita os estudantes a receberem mais de uma interpretação de obra ao mesmo tempo. (...) A arte contemporânea é a de que pode haver muitas formas significativas. Desde que há diferentes contextos que podem ser relevantes para um trabalho, podem haver muitas interpretações dele e elas não necessariamente excluem-se umas às outras.

Segundo Pillar (2001, p. 25-6),

uma leitura se torna significativa quando estabelecemos relações entre o objeto de leitura e nossas experiências de leitor (...). O nosso olhar não é ingênuo, ele está comprometido com o nosso passado, com nossas experiências, com nossa época e lugar, com nossos referenciais. Não há o dado absoluto e não se pode ter uma única visão, uma só leitura, mas se deseja lançar múltiplos olhares sobre um mesmo objeto.

A Proposta Triangular, para muitos educadores, é entendida como releitura no sentido de cópia e muitos educandos, condicionados a esta distorção metodológica, estranham e resistem, não permitindo a experiência da fruição e da criação, sentem-se inseguros e com uma autocrítica muito forte, mas a proposta vai além da reprodução. A releitura entendida como cópia, segundo Pillar,

é o aprimoramento técnico, sem transformação, sem interpretação, sem criação. Já na releitura há transformação, interpretação, criação com base num referencial, num texto visual que pode estar explícito ou implícito na obra final. Aqui o que se busca é a criação e não a reprodução de uma imagem (PILLAR, 2001, p. 18).

\section{OS PCNs-ARTE}


Os Parâmetros Curriculares Nacionais (PCNs) foram elaborados a partir da Constituição Nacional para regulamentar a LDB, “com a intenção de ampliar e aprofundar um debate educacional que (...) dê origem a uma transformação positiva no sistema educacional brasileiro", segundo declarou o Ministro da Educação e do Desporto, no texto “Ao Professor”, que abre todos os volumes dos PCNs de 5 a $8^{\text {a }}$ séries. Os PCNs já estão nas escolas, influenciando a prática pedagógica e também gerando inquietações.

Em todos os ciclos da educação fundamental, os Parâmetros Curriculares dão à área de Arte uma grande abrangência, propondo quatro modalidades artísticas: 1) artes visuais - com maior amplitude que artes plásticas, englobando artes gráficas, vídeo, cinema, fotografia e as novas tecnologias, como arte em computador; 2) música; 3) teatro; 4) dança, que é demarcada como uma modalidade específica. Nos PCNs-Arte, as propostas para essas diversas linguagens artísticas estão submetidas à orientação geral, apresentada na primeira parte do documento, que estabelece três diretrizes básicas para a ação pedagógica. São diretrizes que retomam, embora não explicitamente, os eixos da chamada "Metodologia Triangular" - ou melhor, "Proposta Triangular" -, defendida por Ana Mae Barbosa na área de artes plásticas.

Segundo os Parâmetros, o "conjunto de conteúdos está articulado dentro do processo de ensino e aprendizagem e explicitado por intermédio de ações em três eixos norteadores: produzir, apreciar e contextualizar" (PCN-Arte, p. 49). Vale ressaltar que, em nosso país, a Proposta Triangular representa a tendência de resgate dos conteúdos específicos da área, na medida em que apresenta, como base para a ação pedagógica, três ações mental e sensorialmente básicas que dizem respeito ao modo como se processa o conhecimento em arte. Os PCNs-Arte apresentam uma proposta tão abrangente, porém não chegam a apresentar de modo claro a forma de encaminhar concretamente o trabalho com as diversas linguagens artísticas. As disposições neste sentido são poucas e dispersas pelo texto.

Os PCNs-Arte optam pela organização dos conteúdos por modalidade artística, e não por ciclo, como nos documentos das demais áreas, delegando às escolas a indicação das linguagens artísticas e "da sua seqüência no andamento curricular" (PCN-Arte, p. 54). Neste sentido, sugerem que "a critério das escolas e respectivos professores (...), os projetos curriculares se preocupem em variar as formas artísticas propostas ao longo da escolaridade, quando serão trabalhadas Artes Visuais, Dança, Música ou Teatro” (PCN-Arte, p. 62-63).

A flexibilidade presente na proposta de Arte procura considerar as diferenciadas condições das escolas, levando em conta também a disponibilidade de recursos humanos. "Os 
conteúdos podem ser trabalhados em qualquer ordem, conforme decisão do professor, em conformidade com o desenho curricular de sua equipe" (PCN-Arte, p. 49).

Cada escola pode e deve, portanto, elaborar sua própria proposta pedagógica. Se construída de forma participativa e compromissada - não se revestindo apenas de um caráter burocrático -, deve decidir como utilizar os recursos humanos e materiais disponíveis, de modo a atender às necessidades específicas de seu alunado. A proposta pedagógica é, pois, o espaço ideal para definir o melhor modo de encaminhar o trabalho de arte na escola, fazendo uso da autonomia prevista na LDB e nas Diretrizes Curriculares, e atendendo à flexibilidade da proposta dos PCNs-Arte. Neste quadro, sendo analisados e discutidos com cuidado, os PCNs-Arte podem ser utilizados para respaldar uma atuação mais aprofundada em determinada linguagem artística, ou ainda como base para reivindicar as condições necessárias para uma prática pedagógica de qualidade.

Ana Mae faz uma crítica aos manuais de arte, aos PCNs, aos referenciais e a tudo o que possa limitar o campo de possibilidades que a arte oferece. Segundo a autora,

os PCNs brasileiros dirigidos por um educador espanhol, des-historicizam nossa experiência educacional para se apresentarem como novidade e receita para a salvação da Educação Nacional (...). Infelizmente os PCNs não estão surtindo efeito, e a prova é que o próprio Ministério de Educação editou uma série designada Parâmetros em Ação, que é uma espécie de cartilha para o uso dos PCNs, determinando a imagem a ser "apreciada" e até o número de minutos para observação da imagem, além do diálogo a ser seguido. A educação bancária de que Paulo Freire falava ronda a Arte/Educação hoje no Brasil (BARBOSA, 2002, p. 8-9).

\section{O ENSINO DE ARTES EM SÃO PAULO}

As avaliações do ensino fundamental, seja a Prova Brasil, o Saresp e "um diagnóstico elaborado pelas escolas, apontam que, em média, 1,7\% dos alunos que freqüentam o ciclo II ainda não estão alfabetizados. Em algumas escolas esse porcentual é menor e em outras, superior a 3\%" (SME, 2006, p. 12). Um número significativo de alunos apresenta grandes dificuldades em leitura e escrita, e eles embora estejam na escola, pelo sistema de promoção automática são excluídos do acesso ao conhecimento e não têm um acompanhamento adequado para sanar suas deficiências, por isso muitos alunos chegam ao final do ciclo sem saber ler e escrever. 
Para equacionar o problema, a SME lançou em 2006 o programa "Ler e Escrever: prioridade na escola municipal para o ciclo II $^{30}$ tanto para o ensino regular como na educação de jovens e adultos (EJA), com o objetivo de desenvolver a leitura e a escrita nos alunos. Em 2007, o programa se estendeu a todas as áreas do conhecimento e lançou o Referencial de expectativas para o desenvolvimento da competência leitora e escritora no ciclo II do ensino fundamental, com um caderno de orientação didática para cada área, e ao reconhecer a arte como área do conhecimento ${ }^{31}$, apresentou o Caderno de Orientação Didática de Artes para envolver todos os professores no programa Ler e escrever.

Segundo as orientações de SME, todas as áreas devem se comprometer com a promoção da leitura e da escrita dos alunos, oferecendo variedade de gêneros e suportes diferentes de acordo com os gêneros que mais aparecem na área. Os referenciais orientam como planejar e organizar a rotina de leitura e como trabalhar com alunos com dificuldades de leitura e escrita, ressaltando a importância do registro das atividades.

Arte cumpre o papel de ensinar a ler imagens e a intertextualidade com um texto, seja ele científico, jornalístico ou poético; 'estimula os alunos a identificar os elementos que se entrelaçam, que se opõem e que se confrontam, convidando-os a construir sentidos com base em relações intertextuais que fomentem um olhar plural (SME, 2006, p. 22).

O caderno propõe um roteiro para a leitura de imagens através da "pedagogia da pergunta", questionando: por que a leitura e a escrita são também responsabilidade de artes? O que cabe ao professor desenvolver antes da leitura de uma imagem? O que cabe ao professor desenvolver durante a leitura de uma imagem? O que cabe ao professor desenvolver depois da leitura de uma imagem? A última parte do carderno apresenta três sugestões de leitura de imagens. Na esfera artística, faz uma comparação entre os mantos de Bispo do Rosário e o Manto Tupinambá; na esfera jornalística, sugere trabalhar a charge, o cartum e a caricatura; e na esfera de divulgação científica, apresenta a foto noturna da Terra vista à noite e propõe a intertextualidade com a fotografia Yanomami de Claudia Andujar e a foto de

\footnotetext{
${ }^{30}$ Outras ações foram realizadas para o ciclo I, como o PIC para as $4^{\text {as }}$ séries e o Toff nas $1^{\underline{a s}}$ séries.

31 Segundo Meneghetti, a luta pelo reconhecimento de artes como área do conhecimento data de 1989, quando os arte-educadores já discutiam esta questão no simpósio organizado por Ana Mae Barbosa, conforme consta nos anais desse Simpósio: "Precisamos continuar a luta política e conceitual para conseguir que a Arte seja não apenas exigida, mas, também, definida como uma matéria, uma disciplina igual às outras no currículo. Como a Matemática e as Ciências, a Arte tem um domínio, uma linguagem e uma história. Constitui-se, portanto, num campo de estudos específicos e não apenas em mera atividade. A anemia teórica é um dos males da Arte-Educação no Brasil, mesmo na Universidade." Sylvia Bojunga Meneghetti Contexto Nacional: As principais mudanças políticas e conceituais na visão dos arte-educadores. Artigo extraído do BOLETIM Número 20 de Março 1999 Disponível em: <http://www.artenaescola.org.br/pesquise_artigos_texto.php? id_m=10>. Acesso em: 12 jun. 2007.
} 
Catherine Deneuve de Vik Muniz. Para elaboração do caderno, a Secretaria formou um grupo de referência da área de artes com professores da rede municipal que conhecem a realidade da escola.

O caderno de artes sugere alguns "percursos de leitura, com base em metodologias de leitura de imagens desenvolvidas por autores como Robert William Ott (1997), Michael Parsons (1992) e Edmund Burke Feldman (1970)" (SME, 2006, p. 25), embora reconhece e apóia outras metodologias adotadas pelo educador. O papel do professor é conduzir leituras compartilhadas e motivadoras de imagens, com perguntas estimulantes que incitem a curiosidade, provoquem o olhar investigativo e curioso e estimulem o educando a participar e construir significados e compartilhar com a classe.

\subsection{A leitura e escrita em artes}

O mundo contemporâneo é essencialmente visual; recebemos estímulos visuais por vários meios e formas, através da televisão, cinema, vídeo, DVD, games, cartazes de propaganda, cópias xerox, malas diretas e internet. O acúmulo, a velocidade e os efeitos especiais destas informações não pemitem decodificá-las com dissernimento crítico e um olhar mais atento às armadilhas da comunicação. "A grande quantidade de palavras e imagens que vemos no dia-a-dia, expostas de forma caótica e, às vezes, fora do contexto, está voltada quase sempre para gerar consumo" (SME, 2006, p. 15).

Segundo Capra $^{32}$, a cultura ocidental baseada na lógica cartesiana sintetizada no enunciado "Penso, logo existo" dominou pelo pensamento racional e o conhecimento científico e levou à fragmentação das disciplinas acadêmicas e o tratamento do meio ambiente natural como se ele fosse formado de peças separadas. Esta visão fragmentada isolou a ciência da arte, da filosofia e da linguagem e privilegiou o pensamento científico ao estético (CAPRA, 1982, p. 37). Para corrigir esta distorção da cultura escolar e sensível a uma tendência de integrar as áreas do conhecimento humano, a educação "reconhece a arte como área do conhecimento e coloca-a no mesmo patamar de importância das demais disciplinas da escola... A arte é o lugar da experiência tanto da criação quanto da apreciação" (SME, 2006, p. 17).

Através da arte, o educando desenvolve seu olhar sensível mais atento sobre a natureza e a cultura produzida pela humanidade desde a pintura rupestre, passando pelos egípcios, os

32 Fritoj Capra é doutor em Física e autor do livro o Tao da Física. Em Ponto de Mutação, o autor mostra como a "física moderma prenuncia uma revolução iminente da nossa visão do mundo e dos nossos valores" (CULTRIX, 1982, capa). 
gregos e romanos até os modernos e contemporâneos, e passa a compreender o mundo ao seu redor, tornando-os sujeitos da sua época e do seu meio social. Educar para um olhar cultural é a idéia central do caderno (...), e isto significa nutrir um olhar artístico, estético, antropológico, histórico, científico e, sobretudo, crítico (idem, p. 21).

Um mesmo texto pode ter diferentes significados, assim como a leitura de uma imagem pode ligar a diversas experiências e se relacionar com outros textos. A intertextualidade permeia o campo das relações e estabelece ligações entre si, sem criar barreiras, como sugere a própria palavra, relação entre textos, cuja autoria da expressão é atribuída a Kleiman e Moraes (1999, p. 62). "Segundo os autores, para todo leitor, um texto funciona como um mosaico de outros textos" (SME, 2006, p. 22), porém a expressão, muito utilizada por Baktin, é na verdade de autoria de Julia Kristeva: “(...) todo texto se constrói como mosaico de citações, todo texto é absorção e transformação de um outro texto" (KRISTEVA, 1974, p. 64) ${ }^{33}$. Este exemplo mostra como os textos perpassam por autorias, se transformam e podem perder a referência original do autor, seja por desconhecer a autoria ou de forma intencional como no plágio.

Para Pillar (2001, p. 20), “a intertextualidade em liguagens não-verbais mostra uma leitura das imagens de outros artistas sem dizer uma palavra" e se revela em obras que servem de inspiração para grandes pintores. "No Renascimento e início do século XX, podem-se observar obras que remetem a outras obras" (idem, p. 19), como a Vênus de Urbino de Ticiano (1490 - 1576), que inspirou Manet (1832-1883) na criação da sua obra Olímpia (1863), e mais tarde Amadeo Modigliani (1884-1920), com sua obra "Nu Reclinado" (Nova Cultural, 1991, p. 63).

Os textos, no sentido amplo, podem ser compreendidos como todas as linguagens expressivas - literárias, visuais e corporais, e em qualquer esfera, artística, científica ou jornalística, e no cruzamento destas linguagens constrói-se o sentido para a formação de um olhar plural. Todas as áreas fazem leitura de imagens, assim como fazem leituras de textos, mas é no campo das artes que a leitura de imagens, fixas ou em movimento, fornece as ferramentas necessárias para desenvolver as habilidades de ler as imagens, encontrar novos significados e dialogar com o universo da cultura visual. A leitura de imagens, ao contrário da leitura de um texto, permite que se leia a partir de qualquer ponto e cada leitor traça seu próprio percurso de leitura, e neste percurso cria sua rede de conexões intertextuais,

\footnotetext{
${ }^{33}$ Disponível em: <http://www.fcsh.unl.pt/edtl/verbetes/I/intertextualidade.htm>. Acesso em: 5 jan. 2007.
} 
relacionando-se com sua própria experiência e repertório cultural. O papel do educador é "estimular a fruição do aluno por meio de múltiplos caminhos" (SME, 2006, p. 24) entre a música, a literatura, a pintura, o cinema, a fotografia contextualizada com a realidade e com seu repertório cultural, numa aprendizagem significativa em seu nível de conhecimento, para promover o acesso gradativo a outros níveis de compreensão, como explica Vigotsky: “o processo de desenvolvimento progride de forma mais lenta e atrás do processo de aprendizado; desta sequenciação resultam, então, as zonas de desenvolvimento proximal" (VIGOTSKY, 1989, p. 102).

\subsubsection{Antes da leitura de uma imagem: aquecer o olhar}

O planejamento começa ao escolher imagens adequadas à faixa etária dos alunos, ao selecionar e preparar reproduções de boa qualidade para melhor visualização, ao contextualizar cada atividade com uma seqüência coerente com o planejamento, pois a própria imagem indica o contexto social, cultural, histórico e biográfico do autor, e ao conversar com os alunos sobre a importância de ler imagens para saber ler o mundo. Um detalhe do planejamento poderá colocar a perder toda a proposta.

Quanto à seleção das imagens, há várias possibilidades. O acesso à internet cada vez mais democratizado facilita a pesquisa de imagens, artistas e biografias em diferentes fontes para comparar e comprovar a autenticidade das informações, porém de nada adianta elaborar um bom material se não houver equipamentos para apresentá-lo. Uma alternativa seria gravar as imagens em DVD, pois este recurso está mais disponível nas escolas. Mas a melhor opção ainda é a reprodução gráfica, impressa em papel de boa qualidde, tamanho no mínimo A3; com a reprodução em papel, o professor pode levar de uma sala para outra, pode afixar em local visível e acessível para que os alunos tenham mais contato com a imagem e vão se familiarizando e descobrindo cada dia algo novo que antes não havia percebido.

Essas reproduções têm um custo elevado, e para isso é preciso buscar alternativas, como recorrer à APM da escola e solicitar uma verba para aquisição dessas imagens; montar um acervo pessoal, adquirindo essas reproduções ao longo da carreira, como a Pinacoteca Caras, calendários importados de artistas em espiral com 12 imagens em tamanho A2 ou os materiais educativos fornecidos por museus de arte, centros culturais e bienais em cursos para educadores, para serem utilizados em sala de aula. Trabalhar com esse material é muito 
importante, pois com ele o professor prepara o educando para visitar a exposição e ver as obras originais do artista.

O primeiro momento é a preparação a leitura, é o momento do envolvimento do estudante. A leitura de imagens deve preceder de um aquecimento para criar um clima de espectativa, deve aguçar a curiosidade e estimular o olhar, portanto é importante o momento que antecede a leitura de imagem. Para este momento podem ser planejados jogos teatrais, danças, músicas ou performances. "Itten da Bauhaus reservava um tempo em suas aulas para seus alunos exercitarem seus corpos e mentes através de movimentos físicos, respiração controlada e práticas de meditação, o que favorecia a prática de interpretação necessária para o conhecimento das teorias da cor (...)." Ott chama esta etapa de "thought watching, que significa sensibilizar e preparar a atmosfera favorável e não ameaçadora de capacitação para a crítica.” (OTT, 1997, p. 126).

Aquecer o olhar é preparar o aluno para entrar em contato com a experiência estética, diferente da leitura de um texto literário, cuja compreensão só se dá ao final do texto; na imagem visual, ela se apresenta por inteiro ao primeiro contato, global.

Alguns acordos são combinados antes da apresentação da obra, o educando é coparticipante da ação, é uma das partes envolvidas, portanto ao fazer uma sondagem de expectativas, suas vivências e seus conhecimentos prévios sobre o artista ou tema proposto, ao conhecer os objetivos da proposta, ao participar ativamente da proposta e de todo o processo de leitura compartilhada e como serão desenvolvidas as leituras, estabelece-se uma relação de parceria entre educando e educador.

\subsubsection{Durante a leitura de uma imagem: olhar}

É possível ensinar a olhar? Como cativar o olhar? Martins, como mediadora, continua indagando, "como provocar experiências que ressoam na pele, que penetrem no corpo, pois como diz Fernando Pessoa "o que em mim sente, está pensando"? "Como instigar o olhar apressado e superficial e torná-lo um olhar curioso, um olhar estrangeiro?" "Como potencializar ações que gerem o que Dewey denomina experiência estética?" (MARTINS, 2005, p. 6). O mediador tem diante de si o desafio de tecer um olhar, e para isto, da mesma forma com que nos questionamos, as respostas se darão por meio de novas perguntas, uma "pedagogia de perguntas" que originam respostas e se desdobram em novas perguntas e vai 
tecendo "com eles uma rede de relações que articulam uma compreensão do conjunto do grupo de alunos" (SME, p. 33).

A fruição é o caminho inverso, é a pausa, é o tempo reservado para comtemplar, como descreve Gelb (2000, p.56). "Numa época em que as notícias são dadas em pequenos flashes, a contemplação é uma arte esquecida. O tempo dedicado à contemplação é cada vez menor e com isso a alma sofre". Contemplar, segundo a definição do dicionário, é "olhar com muita atenção, meditar sobre". Vem da raiz contemplari, que significa "demarcar um tempo" (com, “com"; templum "templo") ou "olhar com atenção".

A primeira impressão sobre a imagem provoca reações no educando que são expressas para dar sentido ao que está diante dos olhos, sua mente percorre rapidamente os arquivos da memória para encontrar algo que se relacione com aquela imagem. Ao deixar fluir essas falas, e registrá-las no caderno, elas darão pistas ao educador sobre o repertório dos educandos, mas todas as ações anteriores não terão sentido se não forem compartilhadas com todos, "não existe certo ou errado para as falas; o fundamental, no momento de leitura, é expressar o que se vê na imagem" (SME, 2006, p. 32). O registro individual dessas impressões no caderno deixa o pensamento fluir sem o risco de ser censurado pelos colegas. Então, cada um irá ler suas anotações para socializar com a classe. Por meio do registro das falas no suporte, esse material ficará reservado para o final do processo.

É muito gratificante quando se descobre que há muito mais além da primeira impressão, quando se descobre o que não está óbvio, não está evidente; é como um detetive que investiga uma trama ou o olhar de Linceu, o herói da mitologia grega que tinha uma visão excepcional, mas não é preciso ter uma visão excepcional, e sim um olhar atento e curioso como Leonardo Da Vinci.

Ott desenvolveu um sistema de interpretação de obras de arte em museus conhecido como Image Watching. Este sistema pode ser adaptado para o ensino da arte na educação pela sua metodologia bem definida, dividida em cinco categorias, conhecidas como descrevendo, analisando, interpretando, fundamentando e revelando. Ao comparar essa metodologia com o Caderno de Orientação, há uma proposta semelhante em quatro etapas: descrição, análise, interpretação, contextualização. Estas etapas acontecem naturalmente, e não há uma ruptura de uma fase para outra. 
Porém Dewey, em "Experience, Nature and Art", no início do século XX, já abordava a importância da experiência direta da arte com a natureza e em "Arte como Experiência" retoma e insiste na importância de buscar na própria natureza inspiração para a criação e expressão artística. Ana Mae resgata e amplia os conceitos de Dewey, corrigindo distorções sobre a interpretação do seu método como experiência consumatória e incentiva o uso de múltiplas linguagens. Os procedimentos propostos por Ana Mae obedecem a uma ordem crescente de complexidade no desenvolvimento de habilidades para a leitura. Descrição prestar atenção aos elementos que compõem o que se olha; análise - observar a trama do que se olha; interpretação - atribuir sentido ao que se olha; e contextualização - buscar informações sobre a imagem. A escrita deve ser estimulada para ressignificar o aprendizado, organizar suas idéias e concepções sobre tudo o que foi proposto, pois através da escrita ele terá a sensação de que aprendeu algo, e deste aprendizado deixou registros (BARBOSA, 2006).

Na primeira etapa, descrição ou descrevendo, o educando apenas observa a obra, as imagens e o que ele percebe, os elementos formais, as sensações e emoções que a imagem transmite, "para tanto há um tempo de duração desse olhar, um tempo necessário para perceber todas as informações ali contidas.” (op. cit., p.34). Segundo Ott,“o professor é um catalizador e não deve fazer uma palestra ou direcioná-la formalmente" (OTT, 2007, p. 129). Como mediador, o educador estimula a oralidade dos alunos e os deixa falar alto para a classe o que vêem e sentem, repetindo e registrando as falas individuais. É o estímulo para que expressem os sentimentos em relação à imagem, como paz, alegria e medo, e aos elementos formais, como as cores, formas, linhas, texturas.

Na segunda etapa, análise ou analisando, o olhar é mais investigativo para identificar como o artista trabalhou a técnica, os elementos da composição, os aspectos formais e estruturais, os recursos estéticos e as intenções do artista, sem cair em elocubrações. Trata-se de desconstruir a imagem para conhecer sua sintaxe, o que requer um domínio da linguagem visual, e o educador saberá adequá-la ao nível e ciclo de sua turma, apontando na imagem os elementos mais evidentes para que os alunos descubram as idéias e as técnicas que o artista usou na obra. Formular questões sobre estes elementos ajudam a aguçar o olhar e aumentar a percepção. A mesma orientação segue o Guia Básico de Educação Patrimonial do IPHAN (HORTA, 1999, p. 172). Caso os alunos não dominem esses elementos, estarão motivados a ouvir a explicação, pois aplicarão o conhecimento simultaneamente à análise da imagem.

O Caderno apresenta uma tabela que sintetiza os elementos formais da linguagem visual (op. cit., p. 36-7). 


\begin{tabular}{|c|c|}
\hline Imagem & Características \\
\hline Composição & Abstrata, figurativa. \\
\hline Espaço & $\begin{array}{l}\text { Bidimensional, tridimensional, superfícies, planos (o que está em primeiro plano, } \\
\text { em segundo, em terceiro, ao fundo etc.), perspectiva, simetrias, assimetrias, } \\
\text { verticalidade, horizontalidade, equilíbrio, direções, distâncias, movimentos, } \\
\text { distribuição dos elementos (à esquerda, à direita, ao centro, em cima, embaixo } \\
\text { etc.). }\end{array}$ \\
\hline Linhas & $\begin{array}{l}\text { Horizontais, verticais, diagonais, curvas, circulares, trançadas, espiraladas, } \\
\text { torcidas, interrompidas, contínuas, finas, grossas, suaves, fortes etc. }\end{array}$ \\
\hline Cores & $\begin{array}{l}\text { Quentes, frias, claras, escuras, pastel, brilhantes, fracas, fortes, luminosas, } \\
\text { primárias, secundárias, fosforescentes etc. }\end{array}$ \\
\hline Texturas & $\begin{array}{l}\text { Lisas, ásperas, sedosas, aveludadas, rígidas, granuladas, porosas, macias, duras, } \\
\text { arenosas, rugosas, quebradiças, escorregadias, espinhosas etc. }\end{array}$ \\
\hline Formas & $\begin{array}{l}\text { Orgânicas, geométricas, angulares, arredondadas, triangulares, retangulares, } \\
\text { quadradas, cilíndricas, cônicas, piramidais, cheias, vazias etc. }\end{array}$ \\
\hline Luminosidade & Luz, sombra, claros, escuros. \\
\hline Técnicas & $\begin{array}{l}\text { Pintura (guache, aquarela, nanquim, acrílica, óleo), fotografia, desenho (lápis, } \\
\text { carvão, crayon), colagem, gravura (madeira, metal, pedra), escultura (pedra, } \\
\text { arame, gesso), modelagem (argila, Durepox, biscuit), tapeçaria, instalação, mista } \\
\text { etc. }\end{array}$ \\
\hline Gênero & Retrato, paisagem, natureza-morta. \\
\hline Estilo (escola) & $\begin{array}{l}\text { Acadêmico, barroco, impressionista, expressionista, abstrato, cubista, surrealista, } \\
\text { fauvista, modernista, contemporâneo etc. }\end{array}$ \\
\hline
\end{tabular}

A terceira etapa, interpretação ou interpretando, trata das emoções e referências pessoais; é o momento em que o educando relaciona-se com a imagem no que lhe é mais íntimo e significativo, suas experiências pessoais. Nesta etapa o educando já está bem à vontade para dar sua opinião, se gosta ou não gosta. Seja qual for sua opinião, ela será respeitada e acolhida, para que ele desenvolva plenamente sua capacidade de crítica e julgamento, fundamentais à construção de sentidos.

Quando mais exposta a obra, mais viva estará na memória. O professor mediador estimula, incentiva, questiona e conversa com os alunos sobre suas histórias pessoais relacionadas com o objeto de estudo. Ott adverte:

Não pode ser mais frustrante para os alunos do que situar "interpretando" no começo das tentativas de ensinar crítica e iniciar a atividade de crítica com questões concernentes ao sentimento do estudante em relação à obra-de-arte antes das percepções e conceitos básicos terem sido desenvolvidos (OTT, 1997, p. 130). 
A quarta etapa é a contextualização ou fundamentando. É o momento de buscar respostas para as hipóteses levantadas nas etapas anteriores. Até aqui, o olhar foi fundamental para uma imersão na imagem, agora ele quer ir além, quer saber mais sobre o artista e sua arte, seu tempo e o contexto social, político, econômico e cultural. Os textos dialogam com as imagens, e a intertextualidade rompe as barreiras entre as áreas do conhecimento; a escola está aprendendo a ressignificar este espaço pedagógico que se diferencia do organizacional, administrativo e burocrático.

A legenda da obra é o primeiro texto e o mais próximo da obra. Como disse Ana $\mathrm{Mae}^{34}$, “a legenda também é parte da obra-de-arte, porque nela estão contidas muitas informações importantes, como nome do autor, data, título, técnica, origem da obra”. Embora pareça um simples detalhe para o ensino da arte, a legenda abre um portal de informações em várias direções, a começar pelo título da obra, que dialoga com a própria obra e com seu autor; quando a obra é sem título, outras indagações derivam desta e ampliam as hipóteses sob o olhar de quem vê; a data indica uma época, um contexto histórico, social e político do autor; o nome do autor sugere uma pesquisa biográfica para conhecer sua trajetória familiar, artística e suas influências; na arte moderna e contemporânea, a expressão técnica "mista" pretende sintetizar em uma única palavra toda a complexidade e diversidade da obra, assim como os materias utilizados e as múltiplas linguagens. A intertextualidade da legenda é um incentivo à pesquisa de textos e críticas que são trazidas à classe para serem compartilhadas com os colegas num conjunto de imagens e textos. Como afirma Hernandez (2000, p. 50), "trata-se de expor os estudantes não só ao conhecimento formal, conceitual e prático em relação às artes, mas também à sua consideração como parte da cultura visual de diferentes povos e sociedades".

\subsubsection{Depois da leitura da imagem: olhar além}

A quinta etapa refere-se ao revelando no Sistem Watching de Ott (op. cit., p. 132-3). Como diz o autor, "é proporcionada aos alunos a oportunidade de revelar seu conhecimento a respeito de arte por meio de um ato de expressão artística", trata-se da criação e produção artística do educando, da materialização de todo o percurso desenvolvido desde o aquecimento, thought watching. Na criação artística, o aluno reflete sua própria leitura e os elementos significativos, formais e simbólicos, estéticos e psicológicos, segundo sua visão de mundo, como protagonista. Ao se expressar, cada aluno irá atribuir significado à obra

\footnotetext{
${ }^{34}$ Palavras de Ana Mae proferida em sua palestra no Encontro de Arte Educadores na FAU-USP em 12/4/1998.
} 
apresentada. É na diversidade das obras dos alunos e na troca de experiências e aprendizados que estão a riqueza do aprendizado e a importância da escola como espaço de conhecimento.

$\mathrm{Na}$ experiência artística acontece o encontro entre o artista e o aluno, e de expectador o aluno passa a protagonista, revelando o que ficou de mais significativo do seu contato com a obra. Não se trata de copiar a obra do artista como entendiam a releitura na Proposta Triangular, uma distorção comum nas aulas de arte, confundida com a cópia. Trata-se de ressignificar a obra do artista e dar um tratamento pessoal, que reflita a personalidade e a visão de mundo do aluno. Como explica Pillar:

$\mathrm{Na}$ releitura, um artista parte da obra de outro artista para criar o seu trabalho. Textos que se inter-relacionam lançam uma nova luz sobre a questão da releitura. (...) Neste sentido não há leitura, mas leituras, onde cada um precisa encontrar modos múltiplos de saborear a imagem. (...) Considero, portanto, que leitura e releitura são criações, produções de sentido onde buscamos relações de um texto com o nosso contexto (Pillar, 2001, p.20).

O citacionismo é uma prática comum entre os artistas modernos e contemporâneos que se apropriam de obras consagradas da história da arte para criar suas obras, criando um diálogo entre as duas obras. Dois contextos diferentes para a mesma imagem criam uma intertextualidade nas artes plásticas.

O fazer artístico na sala de aula requer um bom planejamento e muita cumplicidade entre professor e aluno, em relação aos objetivos ou em qualquer etapa do processo, pois em geral a escola não dispõe de salas apropriadas e a duração de uma aula pode impedir que uma atividade comece e termine na mesma aula. O importante é fazer acordos com os alunos, explicar as condições de trabalho, falar sobre a importância da organização do tempo e do espaço da sala de aula para não avançar na aula de outro professor. Enquanto não estiver ao nosso alcance mudar esta realidade, resta a opção de nos adaptarmos a ela.

Os recursos materiais também podem ser obstáculos para a atividade prática, e a educação implica também orientar sobre o uso e a conservação dos materiais para que não haja disperdícios, assim como a manutenção e a limpeza do espaço refletem no resultado do trabalho. A falta de materiais pode ser solucionada quando socializamos o problema com a direção e com a comunidade, e o planejamento das atividades deve prever o tipo e a quantidade de materiais necessários com uma certa antecedência. Embora pareçam de menor importância, os aspectos estruturais interferem no desenvolvimento do trabalho de arte e 
precisam ser levados em consideração. Diferente de um museu, a escola não dispõe de atelier para as aulas de arte.

A leitura de imagens suscita outras leituras intertexturais, e cada leitura toma conotações diferentes pelo olhar de quem vê; os estudos de Gardner demonstram que as inteligências múltiplas: lingüística, musical, lógico matemática, espacial, corporal cinestésica, intra e interpessoal

têm sua forma própria de pensamento ou de processamento de informações, além de seu sistema simbólico. Estes sistemas simbólicos estabelecem o contato entre os aspectos básicos da cognição e a variedade de papéis e funções culturais. ${ }^{35}$

A intertextualidade conecta essas diferentes áreas do conhecimento e amplia o leque de leituras para o educando, que sintonizará com aquelas que lhe fizerem sentido; as leituras significativas para um aluno não serão igualmente para outros.

Os textos variam quanto ao gênero e ao suporte, cada texto tem características próprias e se presta a diferentes objetivos, por exemplo: uma biografia pode ser apresentada em livros ilustrados, filmes ou xerox, cada um destes suportes, apesar de conteúdos semelhantes, promove diferentes aprendizagens. De acordo com o perfil intelectual do educando, o texto pode abrir um campo de possibilidades infinitas e levar a vários caminhos e novas interpretações. Ao circular textos na sala de aula, o educando experimenta diferentes linguagens, das mais simples às mais complexas, como biografias, resenhas, folhetos, artigos e críticas de jornal e revistas, músicas e poesias; as opções são muitas e quanto mais opções forem apresentadas, seja pelo educador ou pelo aluno, estas serão sempre bem-vindas.

Assim como a leitura, a escrita é um instrumento de ressignificação do aprendizado; a escrita ajuda a organizar o pensamento, fixar e refletir sobre os conteúdos aprendidos, expressar e se comunicar. $\mathrm{O}$ ato de escrever desenvolve a capacidade de abstração e das habilidades cognitivas; só se aprende escrever, escrevendo. As diferenças entre a linguagem verbal e a escrita são reconhecidas quando esperimentamos colocar no papel nossas idéias. Estas idéias tomam a forma de texto, com regras próprias, que serão apreendidas pela própria experiência. A prática cotidiana da escrita, com suas regras de gramática, sintaxe e semântica, leva a um processo de automação, reduzindo os erros e aumentando o prazer da escrita. Os

${ }_{35}$ Maria Clara S. Salgado Gama é Doutora em Educação Especial pela Universidade de Colúmbia, Nova Iorque . Disponível em: $<$ http://www.homemdemello.com.br/psicologia/intelmult.html $>$. Acesso em: 10 maio 2007. 
textos produzidos pelos educandos e socializados em sala de aula aumentam a auto-estima e incentivam outros educandos à escrita. Nesse sentido,

gradativamente (esses adolescentes) terão contato com outras visões de mundo, ampliarão os conhecimentos de si, do mundo que o cerca. Sendo autor e leitor de textos, eles se tornarão leitores críticos e verificarão que o domínio da variedade padrão possui implicações sociais (SERCUNDES, 2000, p. 94).

Convencer o aluno a escrever na aula de artes não é uma tarefa muito simples, mas há meios de motivá-los à escrita, como a elaboração de um roteiro para teatro, uma resenha ou uma crítica sobre o quadro onde ele irá expor suas opiniões, ou um relato de impressões sobre as etapas do trabalho. D'Ambrósio sugere um caderno de lição de casa para a elaboração de relatórios escritos de todas as atividades. Koudela fala do protocolo nos jogos teatrais, um relato de impressões da atividade do encontro com conexões com outros textos e imagens. Nos primeiros minutos do encontro seguinte, o enunciado é apreciado por todos. De início, esses relatos são tímidos e desarticulados, com pouco conteúdo, mas o hábito de produzir protocolos e discuti-los permite um aprofundamento sobre o fazer teatral, e logo começa a surgir uma diversidade de idéias e materiais, e como numa bola de neve tende a crescer e se tornar muito gratificante tanto ouvir como produzir.

A intenet se tornou uma fonte de pesquisa indispensável. Pela rapidez, quantidade e variedade de informações, a tecnologia da informação fascina o educando e isto o leva a crer que basta um click e as informações surgem como num passe de mágica. Na verdade não é tão simples assim, a mediação do educador é muito importante, principalmente na iniciação do processo de formação da competência leitora e escritora do educando. A pesquisa, seja em livros ou na internet, implica uma metodologia que oriente cada etapa a ser seguida, a começar pela definição do assunto, problematização com elaboração de questões e hipóteses, fontes de pesquisa bibliográfica ou, através da internet, resumos, fichamento e texto final com introdução, desenvolvimento, conclusão e bibliografia.

Ao final dos trabalhos, expor as atividades realizadas representa o coroamento do processo que envolveu, direta ou indiretamente, toda a comunidade. A curadoria pedagógica tem o papel de organizar e criar um percurso educativo no espaço expositivo, pensando nos objetivos a serem alcançados. A exposição aumenta a auto-estima dos educandos e cria uma imagem positiva de artes como área do conhecimento, desfazendo o conceito de área adjunta de apoio às demais disciplinas para apresentação em datas comemorativas. A participação dos 
educandos é fundamental para estimular o protagonismo, a criatividade, a iniciativa e o voluntariado, pois esta atividade não visa uma avaliação individual.

O planejamento da exposição começa com a escolha do tema, um título que sintetize a idéia central da exposição e uma logomarca que crie um impacto, desperte a curiosidade e motive o maior número de pessoas a visitar a exposição. Uma planta baixa definirá a circulação e o percurso da exposição, a maneira como as obras dialogam entre si e com o visitante, os critérios de organização das obras, por tema, por turma etc., a altura das obras ao nível dos olhos, a iluminação, os textos explicativos, as legendas em todas as obras e a interatividade, com os alunos monitores.

A montagem da exposição começa com a preparação do material expositivo com alguma antecedência, por isso é importante elaborar um cronograma de atividades, pensando em cada etapa da exposição. Os alunos são orientados a emoldurar seus trabalhos e a fazer as legendas com nome, série, título da obra, medidas, técnica e data. A participação dos pais aproxima a comunidade da escola e é motivo de orgulho para os alunos. A divulgação da exposição na escola é feita pricipalmete de forma oral, mas não dispensa os recursos disponíveis na escola como conteúdo de aprendizagem. Deve-se criar um spot veiculação na rádio comunitária, mandar convites ou entregar filipetas e folhetos explicativos da exposição. Deve-se colocar um caderno de visitas na entrada para registro de visitas e impressões.

Nada se compara à visita a uma exposição em museus e espaços culturais. Segundo Ott,

a arte, ensinada no contexto das coleções dos museus, reflete os valores estéticos intrínsecos da obra-de-arte e as preferências cognitivas dos alunos que estão neste processo de aprendizagem, mas arte proporciona um registro da civilização por meio da aobrdagem das idéias artísticas essenciais e das expressões que serviram para celebrar e continuar a refletir a alegria de viver (OTT, 1997, p. 112).

O museu oferece uma experiência única ao colocar diante do visitante a obra original do artista; o prazer, o encantamento, a surpresa e o estranhamento são emoções que só podem ser vividas com a obra original. O relacionamento entre a escola e o museu tem melhorado a cada ano, os monitores das exposições criam um clima favorável aos alunos, adequando o tempo da visita ao seu ritmo, permitindo uma fruição do objeto. Muitas pessoas deixaram de visitar exposições, pois ainda têm consigo a idéia de que o monitor decora um texto e "despeja" sobre o visitante, não permitindo que ele pergunte ou simplesmente aprecie a obra sem interferências ou ruídos. Hoje os monitores são treinados e estudam as obras, os artistas e 
os objetivos da curadoria, além de saber como lidar com diferentes públicos e com pessoas com necessidades especiais.

Segundo Ana Mae,

a Pedagogia Questionadora de muitas exposições do Centro Cultural Banco do Brasil de São Paulo (CCBB/SP) é a melhor forma de mediação. Em vez de visita guiada, com informações fornecidas pelos monitores (ou Educadores, como prefiro chamar), são propostas questões que exigem reflexão, análise e interpretação sem que sejam evitadas informações que esclarecem e/ou apoiam interpretações. Mesmo esta linha, se não instituir o diálogo entre monitor e visitante, pode ser irritante quando o monitor apenas se limita a devolver a pergunta do visitante. Há uma outra linha que felizmente agora só raramente se vê, mas que, no caso de mega- exposições, ainda acontece. Trata-se da submissão da ação educacional aos desígnios do curador, funcionando o monitor como mero reprodutor das idéias do curador às quais algumas vezes, repete sem nem entender muito bem ${ }^{36}$ (BARBOSA, 2004).

A escola tem papel primordial em proporcionar essas visitas aos educandos, pois muitos não ultrapassam os limites do seu bairro, portanto não conhecem a cidade onde moram e o patrimônio cultural de sua cidade. As exposições, em geral, são temporárias e precisam ser agendadas com antecedência. Quando o professor visita a exposição previamente, ele terá em mente a obra que irá trabalhar com os alunos e os objetivos a serem alcançados. Uma grande exposição permanece em cartaz de dois a três meses, deve ter um programa educativo para educadores, com fornecimento de bom material para trabalhar em sala de aula, o agendamento de visitas, que são acompanhadas por monitores treinados e, ao final da exposição, os visitantes participam de uma atividade no atelier. Todo este acolhimento ajuda a quebrar preconceitos e tabus e abre a possibilidade de a criança retornar à exposição com os pais, motivados pelo filho.

O custo de uma exposição é muito alto e requer planejamento minucioso e com muita responsabilidade. A curadoria planeja com muita antecedência, pesquisa e negocia com os museus de origem das obras e proprietários particulares, planeja o espaço físico, coordena a equipe de montagem, cuida do transporte, das embalagens, dos seguros, dos cuidados especiais e da divulgação da exposição. Pela TV a divulgação é feita através de reportagens, e raramente com publicidade, devido ao alto custo de veiculação. Montar uma exposição de arte

\footnotetext{
36 Ana Mae Barbosa, Museus como Laboratório. Artigo publicado na Revista Museus. Disponível em: $<$ http://www.revistamuseu.com.br/artigos/art_.asp?id=3733>. Acesso em: 16 jan. 2008.
} 
não é tarefa da escola, mas sua função não é menos importante, pois sem o espectador o museu deixa de cumprir seu papel social. É da resposabilidade de todos cuidar para que a cultura da humanidade seja acessível a todo cidadão; é papel do museu cuidar do patrimônio da humanidade.

A visita ao museu é uma tarefa muito delicada, pois envolve despesas com transporte e alimentação e a responsabilidade da escola e dos professores com a saída dos alunos do espaço escolar. No entanto, é muito gratificante ver no brilho dos olhos das crianças a alegria deste momento único. Quando o aluno está preparado para visitar a exposição, por meio das etapas previamente trabalhadas em sala de aula, o aproveitamento é muito maior, e ele desfrutará de um prazer estético. Não raras vezes, encontro ex-alunos e eles ainda guardam a lembrança da exposição de arte que visitaram com a escola; de um ano de convivência em sala de aula e um dia na exposição, o que ficou na memória foi "aquele dia". A visita à exposição conjuga o passeio cultural com o lazer e torna-se um evento para os alunos ao conhecerem outros pontos da cidade; aproxima o professor do aluno e estreita os laços de amizade da classe e o professor deve cuidar para que este clima mágico seja mantido durante todo o passeio.

Conhecer o autor da obra parece ser impossível, mas se for um artista contemporâneo, isto não será tão difícil como parece. Os artistas são muito ocupados, viajam muito, e por serem autônomos se ocupam de várias atividades, mesmo quando são vinculados a uma galeria de arte, que se encarrega de divulgar seu trabalho e promover exposições nacionais e internacionais. Mas se suas obras estão expostas, não são raras as vezes em que o artista retorna à exposição depois da vernissage. Recordo-me de um encontro com o artista na exposição de Cildo Meireles no Museu de Arte Moderna em 2000, quando participava do curso para educadores. A professora nos avisou que o artista estaria lá naquela tarde para uma conversa com os participantes do curso. Após a visita, tivemos o contato com o artista brasileiro, que vive nos Estados Unidos. Ele nos contou sobre sua infância, suas lembranças e principais influências, falou de suas obras e do contexto em que elas foram criadas, a relação com a política (e com a polícia), ao transgredir as normas sociais; também falou do seu processo de criação, sobre a arte no Brasil e respondeu questões formuladas pelos educadores. Este encontro foi muito significativo, e as obras foram mais bem compreendidas.

Em 2005, na exposição da Pré-História no Brasil, um dia antes da inauguração, ao visitar o Centro Cultural Banco do Brasil (CCBB), encontrei a Dr $^{\text {a }}$ Niède Guidon ${ }^{37}$ e a

\footnotetext{
37 A Dra. Niède é arqueóloga brasileira, responsável pelo sítio arqueológico de São Raimundo Nonato no Piauí.
} Seu trabalho de arqueologia e conscientização sobre a importância da preservação deste importante 
reconheci. Conversamos rapidamente sobre seu trabalho e o projeto; disse que estava programando uma visita com meus alunos e pedi a ela que deixasse uma mensagem, e em um cartão ela escreveu: "Venha conhecer São Raimundo. Niède". Ao preparar os alunos para visitar a exposição, contei-lhes sobre o encontro e mostrei a mensagem. Este simples gesto mudou o olhar dos alunos, aumentou o interesse e aproximou-os da exposição.

O contato com artistas vivos desmistifica a idéia de que a obra-de-arte é de artistas mortos, que viveram no passado; esta idéia tem sua lógica pelas obras publicadas nos livros didáticos de história que, em geral, utilizam essas imagens para ilustrar um período da história; outra razão é a mistificação do artista como um ser inatingível e sobrenatural, uma herança cultural que vem da época da Missão Artística Francesa no Brasil, no século XVIII. “Ainda hoje, coloca a obra-de-arte em um patamar elevado (...) e mantém certa conotação aristocrática, de lazer e de marca regitrada da elite" (SME, 2006, p. 51).

Há uma distorção conceitual sobre arte. Para muitos, arte é somente aquela apresentada em museus dos artistas consagrados pela crítica e pela história, mas o conceito de arte é muito mais amplo e varia de uma cultura para outra, como afirma Coli:

Ora, é importante ter em mente que a idéia de arte não é própria a todas as culturas e que a nossa possui uma maneira muito específica de concebê-la (...). A noção de arte que hoje possuímos - leiga, enciclopédica - não teria sentido para o artesão-artista que esculpia os portais românicos ou fabricava vitrais góticos. Nem para o escultor que realizava Apolo no mármore ou Poseidon no bronze. Nem o pintor que decorava as grutas de Altamira ou Lascaux. Desse modo, o "em si” da obra-de-arte, ao qual nos referimos, não é uma imanência, é uma projeção. Somos nós que enunciamos o "em si" da arte, aquilo que nos objetos é, para nós, arte (COLI, 2004, p.64).

A arte se manifesta de muitas formas em todas as culturas, como na diversidade das artes indígena e afro-brasileiras, das culturas populares, dos inconscientes produzidos por doentes mentais e apresentadas na Mostra Brasil +500 , em 2000, no Ibirapuera, e a exposição “Carnavalescos”, em 1987 no MAC, como relata Ana Mae:

\footnotetext{
"A exposição Carnavalescos" de 1987, a primeira deste projeto, causou escândalo entre os artistas da Universidade e entre museólogos, que viram, com repúdio, as ruas subirem as rampas do Museu e as escultóricas alegorias de Escolas de Samba - de "artistas" como Fernando Pinto - serem pólo de atração do espaço sagrado dos eruditos (BARBOSA, 1999, p. 7) (O MAC Banco Safra).
} 
A arte, vista sob esse prisma, abre espaço para os artistas populares que residem próximos à escola e teriam muito a dizer aos alunos sobre seu trabalho e sua produção artística. A escola pode organizar um encontro com os artistas da região.

A internet abre uma nova possibilidade de encontro com o artista e a pesquisa. Ao acessar homepage do artista, o educando entra em contato com uma série de informações úteis à sua pesquisa e ainda pode enviar perguntas, que provavelmente serão respondidas.

O ciclo de aprendizagem se fecha onde começou, com a apresentação da obra que motivou a atividade, sob um novo olhar, mais crítico e reflexivo, um repertório significativo no processo de aprendizagem; o desenvolvimento da leitura propiciou ao educando diversas experiências estéticas. As descobertas feitas pela classe agora parecem saltar da obra, e quanto mais exposta, mais descobertas e novas leituras poderão ser feitas. A arte, como área de conhecimento, cumpre esta importante tarefa na sociedade contemporânea, permitindo fazer uma verdadeira imersão sobre o obejto e extrair dele caminhos inimagináveis a princípio.

Esse percurso exige muito empenho e perseverança, paciência e persistência do educador, pois se trata de educar um olhar superestimulado, superexposto a milhões de imagens e precisava de uma pausa, para ver verdadeiramente. Ao retomar a obra e expô-la na sala por um bom tempo para novas descobertas, cada um poderá se expressar, falando sobre novas descobertas. Estas falas, ao serem confrontadas com as primeiras registradas, mostram novas leituras, e isto ocorre sempre que relemos um livro ou apreciamos uma obra-de-arte. Esta leitura poderá gerar uma nova imagem, um novo painel, com novas falas.

Esse texto fez uma releitura do Caderno de Orientações de Arte da SME, aprofundando cada item e buscando na fonte bibliográfica outras informações correlatas. Esta pesquisa foi a fundamentação teórica necessária para desenvolver o projeto de intercâmbio cultural cidade-campo.

\section{O EDUCANDO DA EMEF COMANDANTE GASTÃO MOUTINHO}


Esta escola está localizada no bairro do Mandaqui, na zona norte da cidade, um bairro próximo ao Horto Florestal do Parque Estadual da Cantareira. Em frente à escola há um grande conjunto habitacional, com edifícios de quatro andares, sem elevador e sem garagens, onde reside grande parte dos educandos.

No projeto original a escola ocupava uma quadra inteira, com a construção do prédio principal, um prédio anexo, uma quadra de esportes, um pátio coberto com palco, refeitório, cozinha, banheiros, sala de vídeo e sala de educação física. Em outra área havia uma piscina e um bosque. Hoje a escola foi desmembrada e a piscina se transformou em Clube Escola da SEME. No prédio anexo funciona o Centro Integrado de Educação de Jovens e Adultos (CIEJA); a quadra ganhou uma cobertura, e do bosque restam poucas árvores. A escola possui rampa de acessibilidade para o andar térreo, onde ficam a secretaria, a equipe técnica, as salas de rádio, informática, artes e de leitura, e mais cinco dalas de aula. No piso superior, são 12 salas de aula.

Em 2007, a escola passou de três para dois turnos, com o aumento de uma hora aula por turno. A redução das turmas para acomodar dois turnos implicou transformar espaços da escola em salas de aula, como a sala de artes, a sala de reunião e o auditório. Os turnos foram formados com turmas do ciclo I e ciclo II, no período matutino, turmas de $3^{\mathrm{a}}$ e $4^{\mathrm{a}}$ séries do ciclo I e II, e o vespertino com turmas de $1^{\underline{a}}$ e $2^{\underline{a}}$ séries dos ciclos I e II. Os professors do ciclo I não tinham contato com os do ciclo II; cada turma tinha o seu coordenador pedagógico. Os professors titulares têm sua sede na escola e os adjuntos na coordenadoria de ensino da região, onde as aulas são distribuídas todo início de ano letivo.

Embora haja outras escolas na região, a demanda por vagas nessa escola é muito grande, devido ao diferencial de fornecer $2 \mathrm{~kg}$ de leite em pó mensalmente às crianças, desde que não faltem às aulas. Todo mês o leite é esperado, e quando a criança não chega com o leite em casa a mãe corre até a escola para justificar as ausências da criança e pedir o leite. Coincidentemente, estas mães são convocadas durante o mês, mas não respondem às convocações; somente na data da entrega do leite elas aparecem.

Desde 2000, a Prefeitura oferece uniforme e material escolar. A cada ano aumenta o número itens dessa lista. Nesse ano foram distribuídos meias e tênis, em uma complicada logística para a escola administrar. Este fator cria um desvio de funções, aumenta o desperdício de material, especialmente o material de arte, pois quando solicitado já não têm mais nenhuma régua, guache, caderno, compasso e esquadros. A escola não pode reter 
nenhum material do educando e também não pode exigir dele nenhum material. Algumas escolas colocam um estoque de material à disposição do professor, como cartolinas, papelcamurça, papel-craft, papel-espelho, papel-crepom, papel-laminado e papel-colorset em cores variadas, guaches e pincéis. O professor precisa se adequar ao material disponível.

Muitas crianças entram na $1^{\underline{a}}$ série e permanecem até a $8^{\underline{a}}$ série, portanto se tornam conhecidas pela equipe pedagógica. Há dois segmentos diferentes de educandos na escola. Um de classe média, que vive nos apartamentos pequenos próximos à escola. São blocos de apartamentos, sem garagens e sem muita opção de lazer. As famílias são mais estruturadas, embora os pais trabalhem fora. As crianças têm seus quartos ou os dividem com irmãos, em geral têm vídeo games, computador e TV. O computador é utilizado para bate-papos e jogos, raramente para pesquisas escolares.

O outro segmento é o das crianças que vêm de bairros próximos à escola, crianças que vivem em favelas, construções que invadem as calçadas, se verticalizam e se espremem lado a lado. Nesses imóveis moram várias famílias juntas, até três gerações, com famílias numerosas, ocupando às vezes um cômodo cada família. Outras crianças moram em porões de sobrados, um cômodo junto à cozinha e o banheiro interno.

As crianças não têm privacidade para estudar, por exemplo, um quarto, e muitas vezes têm de cuidar dos irmãos menores enquanto a mãe e o pai saem para trabalhar. Há muitos casos de famílias cujos irmãos não são do mesmo pai, e a mãe é quem acaba criando sozinha os filhos. Essas mães não têm profissão e, portanto, são diaristas, empregadas domésticas, trabalham em pequenas fábricas ou no supermercado próximo à sua residência.

Muitas famílias não têm a figura paterna, ou os pais são alcoólatras ou viciados, e as crianças convivem com a violência dentro de casa. Esta violência pode ser constatada quando a criança chega à escola com marcas de espancamento ou violência sexual. Essas crianças apresentam baixo rendimento escolar e atraso na alfabetização, não têm referências familiares, pois, em geral, são famílias desestruturadas, com baixa renda e muito numerosas. Em muitos casos já é possível prever o futuro não muito promissor dessas crianças. São crianças que passam a noite na rua, para ganhar algum dinheiro, e são muito vulneráveis à droga. As meninas, na $8^{\mathrm{a}}$ série, já estão grávidas. A incidência não é maior devido ao apoio da escola, que muitas vezes é a única referência social para a família. 
Há alunos muito pobres com excelente aproveitamento escolar e outros, ao contrário, de situação econômica melhor, com baixo rendimento. Este forte estigma de condição econômica, cor ou raça causa surpresa, pois pode parecer estranho, mas o comum é o inverso. A tendência é achar que esses casos são exceção.

A prática do bulling é comum na escola; colocar apelidos e zombar dos colegas são uma constante. Se um aluno tem algum problema, ele fica estigmatizado na escola e dificilmente conseguirá mudar sua imagem. Os educandos com problemas de disciplina atrapalham as aulas e os colegas interessados, e isto prejudica todo o grupo. Há casos de inclusão de crianças com deficiência física ou mental. Essas crianças convivem com as demais, sem nenhum tratamento diferenciado durante as aulas. Quando se nota um problema, elas são encaminhadas à Coordenação Pedagógica, para que as providências sejam tomadas.

A televisão é o principal veículo de informação e lazer, mas os vídeo games e o computador estão presentes em alguns domicílios. Os alunos da manhã acordam cedo e vão para a escola. À tarde assistem à televisão, brincam com o vídeo game, na rua ou em casa de amigos, e os que têm computador usam-no somente para os bate-papos ou para baixar músicas e gravá-las em MP3, que levam na escola. Alguns alunos trazem celulares com câmera fotográfica, MP3, MP4 e até MP5, com caixas de som para ouvir na sala de aula.

Uma vez por semana os alunos vão à sala de informática com o acompanhamento do professor orientador de informática educativa (POIE). Em anos anteriores, o professor de qualquer área companhava os alunos na sala de informática e com o apoio do POIE desenvolvia sua proposta. Agora o professor não acompanha sua turma, mas pode desenvolver um projeto em parceria.

O mesmo acontece com a sala de leitura, o professor da sala de leitura tem hoje uma aula por semana com cada turma, mas devido às alterações do espaço físico da escola, a sala é sempre requisitada para depósito de uniformes e leite, impedindo o professor de desenvolver um trabalho pedagógico. A falta de espaços alternativos ou dos espaços conquistados em anos anteriores limitou muito o trabalho dos educadores durante todo o ano letivo, e nenhum professor conseguiu apresentar um vídeo ou filme.

Uma nova portaria criou a função do educador comunitário, exercida por um professor da rede, cuja função é agendar passeios culturais, fretar ônibus e coordenar as atividades dos oficineiros das ONGs, que entraram na escola em 2006 para oferecer cursos diversos às 
crianças do ciclo I. As visitas a exposições e museus devem ser solicitadas ao educador, e caso ele não consiga ônibus junto à Coordenadoria de Ensino o passeio não se realiza, porque não se pode cobrar nenhuma despesa do aluno.

A escola não tem um grêmio estudantil, mas tem a rádio comunitária do Projeto Educom. Rádio. Funciona nos intervalos, com uma programação semanal de músicas de acordo com o gênero musical do dia. A equipe que cuida da rádio é fixa, e isto gerou protesto dos alunos, que reinvindicavam uma rádio mais democrática.

Os pais das crianças que apresentam problemas de disciplina ou dificuldade de aprendizagem são convocados. Eles chegam irritados, e após uma conversa com a Coordenação Pedagógica (CP) acabam desabafando seus problemas. A escola tenta ajudar dentro de suas possibilidades, encaminhando para o Posto de Saúde mais próximo, ou até oferecendo uma cesta básica de alimentos.

Durante o ano letivo de 2007, a escola foi cenário de muito vandalismo e depredação do patrimônio público. Os alunos das $8^{\mathrm{a}}$ série quebraram vetiladores; atearam fogo no cesto de lixo da sala; fizeram guerra de maçãs e comida no pátio; jogaram cadeiras de uma sala para outra; arremessaram um livro pelo corredor na troca de aula, atingindo uma professora, que veio a desmaiar; saíam da sala sem autorização; apagavam as luzes na chave-geral; entravam em outras salas e simulavam os grupos de terroristas do PCC, ameaçando professores e alunos; e abriam as torneiras dos banheiros, deixando transbordar e desperdiçar água. Todo este clima foi vivido na escola e, nenhuma medida que a direção tomasse conseguiu reverter a situação de indisciplina.

Essas atitudes, na versão dos professores, eram uma reação à relação autoritária e fria entre a direção da escola e os alunos, mas segundo a direção o problema estava em alguns alunos de outros bairros, recém-chegados à escola, que lideravam as classes em prejuízo das aulas e dos alunos interessados. Para Carvalho,

as escolas inclusivas são escolas para todos que reconhecem as diferenças individuais de qualquer aluno. Não só os alunos portadores de deficiência serão considerados de inclusão, mas todos aqueles que por causas endógenas ou exógenas, temporárias ou permanents, apresentam um quadro de dificuldades de aprendizagem ou no desenvolvimento (CARVALHO, 2004). 
É preciso mudar essa cultura de exclusão de alunos que não se enquadram no padrão idealizado pela educação tradicional, pois um grande número de educandos, embora presentes na escola, está alheio ao que acontece na sua classe e faz de tudo para chamar a atenção, como se estivesse pedindo: "Socorro, olhem por nós!".

Alguns educandos dessa escola, com bom aproveitamento escolar, conseguem entrar em boas escolas técnicas de ensino médio (Estadual, Federal ou Liceu de Artes e Ofícios), porém todos os educandos, ao terminarem a $8^{\mathrm{a}}$ série, são encaminhados para o ensino médio em escolas estaduais na região. 


\title{
CAPÍTULO III
}

\section{O INTERCÂMBIO CULTURAL CIDADE-CAMPO}

\section{O ENSINO DA ARTE NUMA ESPIRAL DE APRENDIZAGEM}

\author{
As artes levam-nos à dimensão estética da existência e \\ - conforme o adágio que diz que a natureza imita a obra-de-arte- \\ elas nos ensinam a ver o mundo esteticamente.
}

Edgar Morin

A Proposta Triangular de Ana Mae e o Caderno de Orientação de SME, inspirados na metodologia Image Watching de Ott aplicada à educação, são os referenciais teóricos para o projeto de intercâmbio cultural entre os educandos da cidade e do campo. Com o objetivo de aproximar os educandos da cidade aos do campo por meio da arte, da leitura e da escrita e através da troca de correspondência, promover um exercício de cidadania e a solidariedade, tornando-os protagonistas da sua própria história, a partir das suas próprias referências sociais e culturais. Como disse Ana Mae,

A leitura do discurso visual, que não se resume apenas à análise de formação, cor, linha, volume, equilíbrio, movimento, ritmo, mas principalmente é centrada na significação que esses atributos, em diferentes contextos, conferem à imagem, é um imperativo da contemporaneidade (BARBOSA, 2002, p. 18).

O intercâmbio realizou-se entre educandos do ciclo II da EMEF Cte. Gastão Moutinho, na cidade de São Paulo, na faixa etária 13 a 14 anos, sendo três turmas de $7^{\text {a }}$ séries e quatro turmas de $8^{\mathrm{a}}$ séries com aproximadamente 35 alunos cada, num total aproximado de 240 alunos, com a participação efetiva de $25 \%$ do total de alunos, e educandos do assentamento do MST, Agrovila III na cidade de Itaberá-SP, de $1^{\mathrm{a}}$. a $4^{\mathrm{a}}$. série do ciclo I na faixa etária de 7 a 10 anos com vinte alunos em cada turma, dez alunos da educação de jovens e adultos - EJA na faixa etária de 25 a 50 anos e dez alunos da alfabetização de adultos na faixa etária de 45 a 73 anos. Os alunos da $1^{\mathrm{a}}$. e $2^{\mathrm{a}}$. série realizaram somente desenhos.

A idéia se configurou em três fases: auto-retrato, paisagem e meio ambiente. Cada fase estava relacionada a um conjunto de obras, artistas ou gêneros de linguagem visual e literária. 
Para cada etapa, foram selecionadas reproduções em tamanho grande e uma apresentação em Power Point, para ser apresentada na sala de informática, com o objetivo de oferecer a todos a oportunidade de conhecer as mesmas obras e os mesmos artistas. Cada fase acompanhava um gênero literário, uma música ou uma poesia, associada às imagens de acordo com o tema proposto.

Esta proposta, inspirada nas idéias de D’Ambrósio ${ }^{38}$ ao propor uma aprendizagem em espiral, afirma:

para a elaboração do conhecimento concorre de maneira essencial a percepção que o indivíduo tem de si próprio como: uma realidade individual, nas dimensões sensorial, intuitiva, emocional, racional; uma realidade social, que é o reconhecimento da essencialidade do outro; uma realidade planetária, o que mostra sua dependência do patrimônio natural e cultural e sua responsablidade na preservação; e uma realidade cósmica, levando-o a transcender espaço e tempo e a própria existência, buscando explicações e historicidade (D’AMBRÓSIO, 1998, p. 21).

Para D’Ambrósio, o ensino em espiral começa no indivíduo, se amplia para o espaço, o meio ambiente, a sociedade, para o ser planetário e cósmico, mas sempre retorna com outras abordagens sobre o mesmo tema. Esta metodologia não exclui ou compartimenta nenhuma área do conhecimento, ao contrário, a abordagem sistêmica procura diluir os limites e trabalhar de forma natural cada aspecto da vida, aproximando o conhecimento da vivência de cada um. D’Ambrósio contrapõe a visão cartesiana de ensino compartimentado em disciplinas que dividem e subdividem cada dificuldade para melhor explicar, o que impede a visão holística do próprio indivíduo, sua consciência, seus valores e ética, onde corpo e mente são indissolúveis. Segundo o autor, "embora tendo o indivíduo como ponto de partida, o conhecimento se organiza e toma corpo como um fato social, resultado de interação entre indivíduos. Depende fundalmentalmente do encontro com o 'outro" (idem, p. 40).

As idéias de D’Ambrósio vêm ao encontro do pensamento de Paulo Freire, ao referir as relações homem-mundo:

os homens são consciência de si e, assim, consciência do mundo, porque são um "corpo consciente" vivem uma relação dialética entre os condicionamentos e sua liberdade. Ao se separarem do mundo, que objetivam, ao se separarem sua atividade de si mesmos, ao terem o ponto de decisão de sua atividade em si, em suas relações com o mundo e com os outros, os homens ultrapassam as situações-limite (FREIRE, 2002, p. 90),

38 Ubiratan D’Ambrósio é um dos maiores pesquisadores da visão holística em Ciências e Educação, criou a Etnomatemática, que são as técnicas ou as artes (ticas) de ensinar, entender, explicar, lidar com o ambiente natural (matema), social e imaginário (etno). 
assim como ao pensamento de Ana Mae, ao propor uma educação multicultural e ecológica.

$\mathrm{O}$ projeto foi apresentado às coordenadoras pedagógicas tanto da cidade como do campo e aos professores, para intervenções e contribuições. Durante o desenvolvimento do projeto, conforme a necessidade, novas soluções foram sugeridas para favorecer o diálogo. $\mathrm{O}$ acompanhamento do projeto consistiu na coordenação da comunicação entre todos os envolvidos de São Paulo e da Agrovila e na documentação e no registro de toda a produção.

Ao apresentar a proposta de intercâmbio entre os educandos da cidade e os alunos de uma região com características opostas ao seu grupo, o importante era motivá-los a conhecer novos jovens; alguns se mostraram interessados em participar, outros nem tanto, preferiam esperar sem se envolver. Ao promover o intercâmbio cultural entre educandos do campo e da cidade e conhecer como vivem, pensam e se expressam através da arte, da leitura e da escrita, objetivou-se proporcionar uma nova experiência e ampliar o repertório cultural de todos os educandos, pela igualdade social, pelo respeito à pluralidade cultural, pela autonomia e pelo protagonismo juvenil como forma de incentivo à comunicação e à livre expressão do pensamento. Como diz Boff, "cada um lê com os olhos que têm e interpreta a partir de onde os pés pisam. Todo o ponto de vista é um ponto" (BOFF, 1997, p. 9).

\section{PRIMEIRA FASE: QUEM SOU EU NA CIDADE}

No retrato que me faço - traço a traço às vezes me pinto nuvem, às vezes me pinto árvore... às vezes me pinto coisas de que nem há mais lembrança... ou coisas que não existem mas que um dia existirão...

e, desta lida, em que busco - pouco a pouco minha eterna semelhança, no final, que restará? Um desenho de criança... Corrigido por um louco!

O Auto-Retrato - Mário Quintana

Na primeira fase, o Auto-Retrato, com o objetivo de estimular o autoconhecimento e a liberdade de expressão, promovi uma dinâmica de aquecimento com a pergunta "Quem sou Eu?" Esta pergunta lançava o desafio de refletir sobre sua própria pessoa, suas relações afetivas, culturais e sociais, suas preferências e seus hábitos. Os educandos fizeram uma autoreflexão e escreveram suas histórias pessoais, contaram como vivem e se relacionam com os 
colegas da escola, com a família, com seus animais de estimação e com a cidade onde vivem. Um rico material para aproximar a escola da comunidade escolar.

A apresentação das imagens iniciou-se com a leitura da poesia de Mário Quintana ' $O$ Auto-retrato, ${ }^{39}$. Um poema que ajuda o leitor a romper com a idéia de que o auto-retrato é algo rígido e formal, brinca com as palavras e com a imaginação; abre mil possibilidades para cada um criar sua própria auto-imagem, o seu auto-retrato.

Após essa atividade, apresentei a imagem de Mona Lisa de Leonardo da Vinci. A maioria já conhecia a obra. Deixei-a em exposição por alguns instantes, para fruição. Equanto isso, muitas falas revelavam um conhecimento prévio sobre a obra. Solicitei que anotassem no caderno o que sabiam sobre a obra para apresentar à classe. Os alunos falaram do filme " $\mathrm{O}$ Códido Da Vinci", dos mistérios que envolvem a obra, do sorriso misterioso, das histórias e mitos que envolvem a obra. À medida que falavam eu repetia em voz alta, registrava na lousa todas as impressões e levantava outras questões para estimular o olhar e a emoção.

Da fala dos alunos surgiam novas questões e para a solução destas questões foram levantadas hipóteses que eram exploradas pela classe na busca de alternativas. As hipóteses eram corroboradas ou rejeitadas pela própria classe, e sem desmerecer nenhuma hipótese eu conduzia o debate com perguntas pertinentes ao assunto tratado dirigindo o olhar para uma análise dos elementos formais da obra, apontando para a relação figura-fundo, luz e sombra, cores e tons, texturas, gêneros e estilos. As respostas sugeriam novas perguntas cujas respostas eram repetidas em voz alta e registradas na lousa.

Para trabalhar esta fase em sala de aula, selecionei, do meu acervo pessoal, uma série de reproduções de auto-retratos em tamanho A3 ou A2, de artistas de vários períodos históricos, do Renascimento ao Contemporâneo como: Rembrandt, Delacroix, Paul Gaugin, Cézanne, Picasso e Francis Bacon, com o objetivo de ampliar o repertório de imagens e desmistificar a cérebre espressão "não sei desenhar", uma barreira que bloqueia o jovem aprendiz, permitindo-o estabelecer uma interação com as obras de arte e contextualizar com a vida dos artistas e suas técnicas. A apresentação das imagens na sala de aula se estendeu à sala de informática graças a uma parceria com a professora de informática. Para a sala de informática, preparei uma série ampliada e diversificada de 23 auto-retratos do mesmo período para apresentação em Power Point e apesar de não poder acompanhar as turmas, uma

\footnotetext{
${ }^{39}$ Esta poesia está no livro intitulado Retratos de uma vida sobrenatural, do próprio autor. Disponível em: $<$ http://www.casadobruxo.com.br/poesia/m/auto1.htm>. Acesso em: 20 mar. 2007.
} 
vez por semana nos encontrávamos para troca de experiências e definição dos objetivos da proposta.

A apresentação às classes do conjunto das obras realizou-se primeiro com a fruição de cada obra separadamente, criando uma expectativa e preparando o olhar para a próxima obra. À medida que as obras eram apresentadas, novos elementos eram apontados e comparados entre as obras. A introdução dos elementos formais das imagens assim como os elementos da composição ocorria de acordo com o domínio e nível de conhecimento de cada turma, motivando-os à percepção das cores, luz e sombra, composição, equilíbrio, relação figurafundo. Como afirma Panofsky, "a experiência recriativa de uma obra-de-arte depende não apenas da sensibilidade natural e do preparo visual do espectador, mas também de sua bagagem cultural. Não há espectador totalmente ingênuo" (PANOFSKY, 1979, p. 36).

A leitura permitiu contextualizar cada artista com o seu momento histórico, perceber a evolução da humanidade e a influência da ciência e da tecnologia na arte, como formas indissolúveis do conhecimento, ficando mais evidente nos auto-retratos dos artistas contemporâneos como Paulo Brusky, ao utilizar o raio-X do seu rosto como auto-retrato, ou Letícia Parente e Gretta, que utilizaram recursos digitais para recortar e distorcer suas próprias imagens. Como diz Morin, "a arte é indispensável para a descoberta da ciência, visto que o sujeito, suas qualidades e estratégias terão nela papel muito maior e muito mais reconhecido" (MORIN, 2002, p. 338). As reações de surpresa, estranhamento, humor ou rejeição dos alunos eram imediatas e suas expressões denunciavam as sensações a cada obra apresentada.

Os educandos produziram seus auto-retratos e escreveram cartas de apresentação pessoal, com seus dados pessoais, como idade, sexo, hábitos, lazer, família, vida social, escolar, seus sonhos e ideais. Nas palavras de Regina Machado,

este aprendizado é significativo para nós quando ressoa, conversa com nossa história pessoal, quer dizer, é produto de uma ação conjunta de pensamento, sentimento, percepção, intuição e sensação. Tudo isso junto realiza uma forma, uma imagem interna ou um conjunto delas (MACHADO, 2004, p. 31).

Nas histórias pessoais, os relatos revelavam uma escola até então desconhecida, o lado humano desses educandos, a convivência familiar, seus animais de estimação, seus hábitos de vida e lazer, seus sonhos, a relação com a escola e com os amigos. As cartas revelavam a outra escola, desconhecida para a maioria da comunidade escolar, a escola que de fato existe 
no currículo oculto e acontece à margem da escola oficial. Neste momento eles não tinham um destinatário certo, apenas sabiam que um jovem do campo, da sua idade, iria receber sua carta e talvez aquele jovem também estivesse escrevendo uma carta de igual teor, e em breve chegaria às suas mãos. Em um diálogo solitário com seu amigo imaginário, contavam suas histórias pessoais, íntimas, sem censura, sem cobrança, desvinculado da relação professoraluno, colocando-se por inteiro na relação consigo mesmo e com o próximo.

Miriam Celeste levanta algumas questões sobre a ação mediadora do professor para refletir:

"Como olhar atentamente para a nossa ação mediadora, verificando como os
estágios de desenvolvimento expressivo podem nos ajudar a entender melhor
o grupo que está à nossa frente? Como aprender com nossos acertos e
desacertos, investigando quais as metodologias que podem melhor cercar as
obras que selecionamos para os encontros especiais com a arte? Como nos
munir de informações, mas também saber usá-las, ofertando-as
adequadamente com generosidade e humor, no jogo lúdico de descobertas e
desvelamentos? Como alimentar a paixão que gerou nossa opção
profissional para enfrentar os desafios, o cansaço e a dificuldade na
aproximação com alguns grupos? Como enlaçar todas essas ações com as
propostas pedagógicas e conteúdos que estamos trabalhando?" (MARTINS,
2005, p. 11).

Como diz Ana Cláudia, "o olhar se educa, o gosto se forma” (OLIVEIRA, 1999, p. 97). Asolução foi apresentar auto-retratos dos artistas como possibilidade de educar o olhar, para ampliaação do repertório de imagens e compreensão do papel da arte na história da humanidade; a evolução e as transformações ocorridas no mundo ocidental a partir do Renascimento. A diversidade de imagens e as soluções encontradas pelos diferentes artistas, para se retratarem, através das cores, das linhas e formas, das técnicas e dos recursos, ampliaram as possibilidades de criação de cada educando, não se prendendo a um ou outro artista para criar seus próprios retratos. Rompendo a autocensura, os educandos estavam conscientes de que o auto-retrato não era uma fotografia ou uma imagem real de si mesmo, e sim uma representação da sua imagem, uma criação, um jogo, uma brincadeira com cores e formas e cada um, com seu estilo. Espelhando-se ou não em algum artista, ele se retratou, dando o melhor de si mesmo.

A criação do auto-retrato foi realizada em sala de aula, em casa e na sala de informática. Após serem fotografados, os desenhos originais foram enviados, juntos com suas autobiografias, para os educandos do campo.

\subsection{Quem sou seu na cidade}


A aluna M. da $8^{\mathrm{a}}$. série, apresentou dois auto-retratos, um com um fundo colorido e outro com uma paisagem ao fundo. No segundo desenho, uma paisagem foi criada para compor seu auto-retrato. A solução encontrada para o fundo da sua composição; na relação figura-fundo, no segundo plano, a paisagem foi tão significativa para a aluna e marcou mais sua memória visual do que a própria imagem. Embora não tenha sido uma cópia da paisagem de Da Vinci, ficou evidente a preocupação com uma solução para um segundo plano, e a solução encontrada foi inspirada na obra apresentada. Esse desenho foi feito de memória, em casa, porque em sala de aula há muita interferência dos alunos e pouco tempo para se realizar um trabalho com calma.

No segundo exemplo, o educando V. é influenciado pelo auto-retrato de Picasso. O cubismo no auto-retrato é um diferencial entre os auto-retratos apresentados, choca pelos olhos grandes e pelas formas geométricas muito bem definidas, um marco na arte moderna. Quanto mais uma obra é exposta e explorada, mais influência exerce sobre os alunos, ao apreciar a obra em dois momentos diferentes, na sala de aula e na sala de informática, seguida de uma proposta de uma releitura da obra no Paint Brush ${ }^{40}$, sugerida pela POIE ${ }^{41}$. A atividade proposta pela professora da sala de informática. Embora a proposta não fosse esta, a professora teve autonomia para escolher uma proposta para sua aula e posteriormente, numa conversa sobre o projeto, solicitei à professora que orientasse os alunos a criar outras formas de apresentação dos auto-retratos, por meio da pesquisa na internet e dos auto-retratos criados pelos educandos, fotografados e disponibilizados nos computadores. Embora sem a intenção de dirigir o olhar do educando, a obra permaneceu mais viva na memória do aluno, que recorreu ao cubismo para criar seu auto-retrato, também de memória, em casa.

O terceiro exemplo poderá servir de lição até para os educadores mais experientes. O educando E. é um menino muito quieto e discreto, quase não se nota sua presença na sala de aula, exceto pelos seus desenhos, apresentados somente quando solicitados. Ao apresentar a proposta do auto-retrato, na primeira semana, ele não entregou nenhuma atividade. $\mathrm{O}$ projeto prosseguiu com a realização de uma fase por semana, exceto na primeira fase, pois o tema foi retomado após uma auto-avaliação, com a apresentação dos auto-retratos. Na semana seguinte, em meio às cartas e aos desenhos entregues, surge o seu desenho: o jovem retratouse em plano geral, com um skate na mão. Ao fundo o aluno criou uma sobreposição de três

\footnotetext{
${ }^{40} \mathrm{O}$ Paint Brush é um aplicativo da Microsoft para fazer desenhos e colorir.

${ }^{41}$ Professor orientador de Informática Educatica.
} 
planos com cadeados abertos e fechados; um lápis, uma caneta e um apontador foram desenhados no primeiro plano numa escala desproporcional e se compunham com o personagem principal. As folhas desenhadas ao fundo e os cadeados completavam o fundo da figura, numa composição surreal. Seu estilo, inspirado nos desenhos de mangá, levantou novas questões sobre mídia e educação.

$\mathrm{Na}$ carta, ele relata sua relação com o desenho:

(...) comecei a me interessar por desenhos aos quatro anos de idade, eu me inspirava em desenhos quando assistia pica-pau e Tom e Jerry. Comecei copiando por cima desenhos de revistas, jornais etc., logo quando eu comecei a me interessar por desenhos de estilo mangá, foi no ano passado. Eu fui atrás de algum curso de desenho até que encontrei, era um curso gratuito, você só comprava o material e pronto.

Comecei minha primeira aula, nela tive que mostrar meu estilo de desenhar, eu disse: o estilo mangá; então ele logo me falou que eu não tinha jeito para esse estilo, que eu só tinha jeito para desenhos mais realistas, eu tive mais algumas aulas quando encontrei, em uma revistaria perto de casa, uma revista chamada Desenhe e Publique Mangá. Era uma edição especial e a revista era acompanhada de um DVD. Comecei a treinar, com tanta vontade de provar ao meu professor que eu era capaz de desenhar o estilo que eu estava querendo, o mangá e no meio do ano passado eu comecei a praticar tudo o que aquela revista possuía, até que em certo tempo eu comecei a dominar o estilo mangá. Eu tinha mania de largar todos os desenhos por qualquer canto da casa, um dia aquele professor, o mesmo que disse que eu não iria conseguir desenhar o estilo mangá, tocou a campainha de casa, entrou e ficou surpreso com os desenhos que eu já conseguia fazer no estilo mangá.

Ele chegou até a perguntar para a minha mãe quem tinha feito aqueles desenhos e depois que ela respondeu que tinha sido eu, ele disse à minha mãe brincando: "Eu vou parar seu filho senão ele vai começar a desenhar melhor que eu." Quando eu cheguei ele começou a me perguntar se eu poderia ensinar a ele todas as técnicas do mangá que eu já tinha aprendido. Até hoje eu tenho contato com ele (...).

Gosto muito de andar de skate, é o meu esporte favorito, não ligo muito para as pessoas, tenho poucas amizades, mas eu fico mais calado no meu canto. Hoje ainda não estou satisfeito com os desenhos de mangá que eu faço e estou sempre tentando melhorar traços, etc. Já estou até criando um mangá chamado Carl the Skater boy. Sou fã de muitos animes como os "Cavaleiros do Zodíaco, Guntz, Burst, Angel Frontier Blood, Naruto, Dragon Ball Z, Super Campeões, Dear Boys, Hungry Hart, The Prince of Tennis etc.”.

Essa carta, mais do que uma provocação, revela a essência da pedagogia de Paulo Freire: "Ninguém educa ninguém, ninguém educa a si mesmo, os homens se educam entre si, mediatizados pelo mundo" (FREIRE, 1987, p. 68). Quantas vezes damos as costas para o educando, ignorando seus conhecimentos, sua determinação e seu potencial, impedindo-os de seguir seu próprio caminho. A educação comete muito este "crime", por não conseguir ler nos 
gestos e nas atitudes de seus educandos o que não está nas teorias, e sim no diálogo e na intuição de cada um que faz a escola.

O quarto exemplo selecionado para o estudo desta etapa do projeto foi o auto-retrato do F., um adolescente de 16 anos, alto, magro, afro-descendente, muito simpático e humilde. Atento a todas as atividades, seu auto-retrato me surpreendeu pelo cabelo e pelo recorte do desenho. Por que teria optado pela metade do seu rosto? Por que um cabelo Black Power se ele tem a cabeça quase raspada e usa boné ou capuz da jaqueta? Para responder a estas questões é preciso voltar ao ano anterior, quando um grupo de professores afro-descendentes resolveu assumir o projeto "África história e Cultura", em que as questões raciais foram trabalhadas, sob vários aspectos com profissionalismo e coragem de poucos. Este projeto, a princípio sem apoio, repercutiu não só na escola como na rede, e até na imprensa ${ }^{42}$. Se o objetivo do projeto foi elevar a auto-estima dos alunos afro-descendentes, este desenho é a prova de que os objetivos de uma educação para a diversidade foram alcançados. F. deixou claro que hoje se orgulha de suas raízes históricas.

Alguns desenhos apresentados refletiam a influência dos desenhos animados e mangás, a força da mídia é um desafio para o ensino da arte, daí a importância de proporcionar o contato com obras de arte durante o maior tempo possível, pois assim o educando descobrirá a cada dia algo novo que não havia percebido. A super exposição de imagens da televisão sobre o educando e a repetição diárias dos personagens dos desenhos animados construídos sobre uma estrutura simples favorece a memorização e a abstração de imagens. Estes desenhos servem de referência para o desenvolvimento das habilidades do desenho, como diz Vigotsky, este desenho está na "zona de desenvolvimento proximal” entre o que o educando produz e o objetivo a ser atingido no ensino da arte.

A apreciação de obras de arte influenciou de alguma forma na realização dos desenhos, isto foi costatado pela experiência da semana anterior à apresentação das obras, por ocasião da apresentação da proposta de intercâmbio, com a pergunta “Quem sou eu?” solicitei aos alunos que desenhassem um desenho que melhor os representasse. Os desenhos apresentados eram simples mandalas, iniciais do nome, estrelas e corações soluções simplistas e imediatistas esta resposta me levou a repensar os meios para oferecer ao educando um repertório de imagens mais significativo e a resposta foi significativamente melhor.

\subsection{Quem sou eu no campo}

42 O projeto implantado na escola em 2006 foi publicado no caderno Pais e Mestres do JT, uma parceria com o NCE-ECA USP. 
Todas as atividades desta fase, após serem fotografadas, foram enviadas para a escola de ensino fundamental II em Itaberá-SP. Como as respostas não chegavam, viajei até a cidade de Itaberá e deparei com uma surpresa, as correspondências haviam sido extraviadas e sem as primeiras atividades realizadas pelos educandos da cidade ficaria muito difícil dar continuidade ao projeto. Naquele momento decidi realizar o projeto no assentamento, com o apoio de um educando do MST. Na escola, combinamos de reunir os juvenis da Agrovila à tarde na sala da Ciranda para conhecer o projeto e realizar as atividades de arte. Naquela tarde realizamos as atividades da primeira fase. O grupo participou de todas as atividades da semana. Durante os encontros, após a apresentação das obras, os adolescentes começavam a desenhar e alguns terminavam os desenhos em casa, para entregar no dia seguinte. Nesse encontro as cartas fizeram muita falta, pois eles estavam ansiosos para se corresponderem com algum aluno da cidade. Forneci alguns nomes.

Houve grande interesse pelas obras, diálogo com perguntas e conexões pertinentes, que foram aproveitadas para alimentar o debate e provocar a curiosidade. A falta de um computador inviabilizou a apresentação de todas as imagens apresentadas na cidade, limitando-se às reproduções em papel de seis auto-retratos. Quanto ao fazer artístico, houve uma heterogeneidade nos desenhos, as crianças da mesma faixa etária dos educandos da cidade, apresentavam um nível de qualidade equiparado aos melhores desenhos da cidade, mas houve casos de muita dificuldade em desenhar. Um menino de 12 anos não conseguia desenhar seu auto-retrato, desenhou uma figura pequena no centro da folha e de tanto apagar, desistiu e entregou um papel sujo e borrado. Outro menino de 12 anos, porém interessou-se pelo desenho do E. do qual relatei acima sobre seu interesse por mangá. O menino fez um desenho de mangá e escreveu a sua carta ao menino da cidade. Seu desenho indica a mesma influência que a televisão exerce também no campo. Notei um grande interesse pelos desenhos dos alunos da cidade, que não haviam sido postados.

Às $17 \mathrm{~h}$, outro grupo já se reunia para a aula. Era o grupo de alfabetização do Projeto de Cuba, com aproximadamente dez pessoas, entre elas um senhor de 73 anos, ainda na ativa. Ao ser apresentada, o grupo também se interessou pelo projeto e todos se propuseram a participar. Apresentei-lhes as obras de cada fase e recebi os desenhos da maioria dos participantes. 
O desenho mais significativo foi de uma senhora de 67 anos. Seu auto-retrato era de corpo inteiro ao lado de um vaso de flores da sua altura. Os desenhos em geral equiparavamse ao nível de escolaridade e semelhantes aos desenhos infantis da mesma série, são estereotipados e sem proporção. Uma senhora de 61 anos, desenhou seu auto-retrato com uma cabeça bem grande em relação ao corpo e aos braços, um par de brincos, faces rosadas, sombrancelhas bem delineadas, boca grande e vermelha e o vestido com detalhes no decote e um cinto em cor contrastante. Nota-se neste desenho uma preocupação estética, na simetria do desenho, equilibrado com duas flores iguais nas laterais. Outra senhora desenhou seu autoretrato na mesma proporção dos auto-retratos apresentados, com destaque para o rosto. Neste desenho observa-se uma proporção de medidas. Os olhos amendoados e inclinados dão um ar sensual à imagem, as pupilas indicam um olhar para a direita, numa tentativa de não retratar a imagem de frente. Na figura não há pescoço e a linha corpo está na altura dos lábios. Ao lado do desenho ela escreveu uma carta carinhosa onde relata sua relação com o MST, a vida sossegada e convida seu amigo para vir passear no assentamento.

No período noturno, na escola ao lado da Ciranda, funciona o EJA, Educação de Jovens e Adultos, freqüentado, em geral pelos pais das crianças do ciclo I da escola que funciona no período diurno. A primeira e a segunda fase do projeto foi apresentada aos alunos de EJA nas duas aulas de artes. Falei sobre a proposta e apresentei as obras, numa relação dialógica. O professor de artes acompanhou a apresentação e ao final do encontro, incentivou os alunos a escrever e desenhar como forma de fixação do aprendizado, e em particular agradeceu e afirmou que aprendera muito naquela noite, pois estava iniciando na carreira do magistério e aproveitou a oportunidade para solicitar a doação de qualquer material de arte que eu pudesse dispor para suas aulas, porque na região era muito difícil o acesso aos recursos didáticos que eu havia utilizado para a apresentação. Açõe solidárias como esta são muito incentivadas entre as escolas irmãs. Os educandos desenharam seus auto-retratos, escreveram suas biografias e entregaram na sexta-feira, conforme o combinado, apesar de trabalharem durante o dia e estudarem à noite.

Uma das alunas se destacou pelo interesse e participação diante das obras apresentadas, com várias intervenções durante a exposição e escreveu uma carta dirigida ao aluno da $8^{\mathrm{a}}$. C que a fez circular entre os alunos da escola. A carta comoveu muitos alunos e foi a melhor forma de falar do MST e da vida no assentamento. Em sua carta ela relata o período que passou no acampamento, sob barracos de lona, que passou fome, teve medos, fez 
novenas e contou com o apoio de visitantes e dos assentamentos da região. A resposta do aluno não foi menos comovente, porém carregada de um sentimento de amor e solidariedade.

Os desenhos revelavam o domínio das proporções e da composição, o grande problema foi a falta de papel, muitos alunos fizeram os desenhos na folha de caderno, mas isto não desmerece a qualidade dos trabalhos, ao contrário, serviu de álibi para sensibilizar os alunos da cidade sobre o desperdício de papel e material escolar.

O mais curioso dos trabalhos apresentados foi um auto-retrato com moldura desenhada. Um detalhe que revela o conceito que o educando tem sobre a arte associado à idéia da arte clássica, uma herança cultural da missão francesa no Brasil.

\subsection{A experiência com as crianças do ciclo I}

Na escola da Agrovila, graças ao apoio da diretora, as cartas dos alunos do $3^{\circ}$ e $4^{\circ}$ anos do ciclo I já estavam escritas com os desenhos anexos. De posse das cartas das crianças, procedi à leitura e análise do material como subsídio para dar continuidade ao trabalho. Os desenhos apresentados eram muito semelhantes, com representações esquemáticas da família e casas estereotipadas, sem nenhuma relação direta com suas casas reais, apenas reproduções de modelos aprendidos e copiados. A qualidade da produção escrita não correspondia à produção visual por dois fatores, o primeiro porque a escrita das cartas havia passado pelo processo de correção e reescrita, a linguagem escrita é uma área que as professoras têm domínio e fazem com segurança, porém há muitas controvérsias que envolvem o ensino da arte nos cursos de pedagogia. Ainda hoje é comum encontrar cursos em que as alunas preparam uma pasta de atividades e carregam consigo este material como um kit para as aulas de arte.

A apresentação dos auto-retatos, ocorreu num clima de muita interatividade, e os alunos se divertiram muito com as expressões dos artistas Gaugin e Francis Bacon, imitandoos com expressões faciais, e até levantavam-se da carteira para ver de perto algum detalhe que chamava a atenção. As perguntas eram respondidas simultaneamente com muita vibração e a participação da classe foi unâneme, uma relação muito gratificante com os educandos, que correspondiam e acompanhavam atentos descobrindo novos aspectos nos auto-retratos.

As atividades realizadas com as crianças foram muito produtivas, e os resultados foram surpreendentes. Os auto-retratos revelavam a história da humanidade ao ser 
contextualizada com um fato importante que conectava a algum conhecimento do educando, como Leonardo da Vinci, relacionado com as grandes navegações e o Descobrimento do Brasil; Picasso, com o cubismo e o cinema; Francis Bacon, com a arte contemporânea, a vida e o meio ambiente.

A primeira obra apresentada, a Mona Lisa de Leonardo da Vinci. Uma mulher, jovem, de beleza incontestável e sorriso mistérioso. Após uma fruição silenciosa, começaram a surgir novos olhares, mais investigativos e instigantes como quem quisesse descobrir algo primeiro, todas as hipóteses eram acolhidas e debatidas. Algumas questões serviam de pistas para aguçar o olhar, como o formato do rosto, do nariz, a expressão dos olhos e, por fim, quem foi Gioconda? Em quem Leonardo da Vinci teria se inspirado para fazer aquele retrato?

Os elementos da composição que, segundo Arnheim, estão presentes na obra-de-arte, como ponto, linha, plano, simetria, luz, forma, cor, movimento, unidade, ritmo e equilíbrio, foram trabalhados de diversas formas em cada obra, até que eles próprios se antecipavam em indicar a direção da luz, as linhas que determinavam o movimento e o ritmo das obras, num jogo de investigação e intuição.

Nessa imersão, outras questões surgiram à medida que os auto-retratos eram apresentados. A questão socioeconômica foi muito explorada entre os auto-retratos de Rembrandt e Delacroix através da roupa, da expressão de cada artista, do cabelo, da idade e o do contexto histórico de cada artista. Ao primeiro atribuíram-lhe uma imagem de pobre, uma simples pessoa do povo, e ao segundo, um nobre, pela sua postura, pelo olhar austero e pela roupa. Mesmo sem nunca terem visto as obras, os códigos visuais nelas implícitos indicavam uma leitura correta apenas complementada com algumas curiosidades ou dados biográficos dos artistas, como o hábito de Rembrandt retratar muito moradores de ruas e pessoas comuns, gente do povo, enquanto Delacroix, ao contrário, era um pintor da nobreza, e aos 37 anos já pintava para o rei da França. Essas informações foram suficientes para confirmar as hipóteses levantadas pela classe.

As crianças participaram da apreciação das obras, dialogaram com elas e brincaram, criando histórias e personagens, se emocionaram e se surpreenderam ao ver expressões estranhas ou dúbias como no auto-retrato de Paul Gaugin, que compôs seu auto-retrato com uma auréola, maçãs e uma serpente na mão, símbolos que remetem à religiosidade cristã e se opõem à expressão diabólica do artista, um impasse, um enigma a ser desvendado; uma provocação, um desafio à compreensão das diferentes funções da arte. 
Picasso encantou com seus olhos grandes meio assustados, pela geometria do cubismo, pelas cores fortes. Como em um quebra-cabeça, perguntei quantos triângulos tinham na obra. Entre os triângulos, outras formas eram descobertas e definidas, como trapézios, losangos e outros polígonos, um caminho aberto para trabalhar arte e matemática. Mas por que ele pintava daquele jeito? Surgiu de repente a pergunta. Por que estava com pressa? Por que queria ser diferente? O que será que aconteceu de importante na época em que ele viveu, há 100 anos, no começo do século XX? Vocês gostam de televisão? E o que veio antes da TV que também tinha imagem e movimento junto? A fotografia? O cinema? Será que ele não estaria querendo se pintar em vários ângulos? Provocações como estas estimulavam a olhar e a pensar. A cada resposta uma nova pergunta e novas hipóteses eram levantadas, e neste diálogo eles construíam seu conhecimento. As professoras anotavam e registravam as falas e os nomes dos artistas. Não tive a oportunidade de falar sobre os desdobramentos desse encontro, mas espero ter contribuído para o aproveitamento de outros conteúdos.

Por meio da arte os sentidos também foram estimulados, como na obra de Francis Bacon. Ao perguntar se sabiam fazer caretas, muitas foram apresentadas as mais variadas. Perguntei se tinham medo de caretas, e todos responderam que não, mas ao apresentar o autoretrato do artista, a reação foi imediata, surpresos com as deformações do rosto, alguns se assustaram, outros chegaram mais perto para conferir detalhes. Perguntei: se o quadro tivesse cheiro, que cheiro teria? As respostas 'carniça, podre' refletiam as sensações que a obra transmitia e permitiram conectar com reflexões sobre as questões ambientais contemporâneas e o sentimento do artista em relação à sua visão de mundo, um mundo contemporâneo onde podemos compartilhar, sentir, indignar, resignar ou reagir; a decisão depende de cada um. $\mathrm{O}$ papel da arte foi o de provocar esta reflexão, cabe a cada um decidir o caminho a seguir.

A produção dos auto-retratos, agora com o repertório de imagens ampliado, motivouos a criar os seus próprios auto-retratos, ao compreender que o auto-retrato não era sua própria imagem, mas uma criação artística, assim como faziam os artistas. Sentiram-se livres para se retratarem e estavam acima de qualquer crítica. Alguns agregaram paisagens ao fundo, como parques de diversões, ou preferiam ser representados sobre tratores e cavalos, outros desenhavam molduras como nos quadros para valorizar suas imagens, as meninas caprichavam nos penteados. A orientação era no sentido de explorar todo o espaço do papel, sem se limitar a fazer pequenas imagens. 
As atividades foram realizadas por todos os alunos, da $1^{\underline{a}}$ à $4^{\underline{a}}$ série. Alguns levaram para terminar em casa e trouxeram no dia seguinte. A escassez de papel fez com que dividíssemos uma folha de sulfite ao meio, e isto foi positivo, pois mostrou aos alunos da cidade que enquanto eles desperdiçam papéis, outros não têm nenhuma folha para trabalhar; ironicamente uma região onde há grandes plantações de madeira para a indústria de papel.

\title{
3. SEGUNDA FASE: PAISAGEM NA JANELA
}

\begin{abstract}
Houve um tempo em que minha janela se abriu Sobre uma cidade que parecia feita de giz. (...) Avisto crianças que vão pra escola. Pardais que pulam pelo muro. Gatos que abrem e fecham os olhos, sonhando com pardais. (...) às vezes o galo canta. Às vezes um avião passa (...)

E eu me sinto completamente feliz. (...) É preciso aprender a olhar, para vê-las assim.
\end{abstract}

Cecília Meireles (GADOTTI, 2004, p. 13)

$\mathrm{Na}$ segunda fase, Eu e o meu espaço, o objetivo foi reconhecer e perceber o seu microespaço, ou seja, o espaço mais próximo de si, com suas características, e dialogar com os detalhes deste espaço que o educando vê diariamente, mas nem sempre o percebe, através de um olhar mais atento da sua "paisagem na janela". Para Regina Machado, "cada estudioso, debruçado sobre uma das janelas, vê a paisagem de um ângulo particular e o que ele descobre tem a ver com o lugar em que se posicionou para observá-la" (MACHADO, 2004, p. 19).

Para essa atividade pesquisei e selecionei obras de Tarsila do Amaral, pela ênfase nas paisagens rurais e urbanas, e de Di Cavalcanti, por representar paisagens ao fundo com personagens brasileiros em primeiro plano, numa varanda, sugerindo um olhar de dentro para fora. Também as obras de Magritte e Matisse, com paisagens vistas através de janelas. As imagens foram apresentadas com a música "Paisagem da janela", de Milton Nascimento, para uma fruição audiovisual.

A importância de Tarsila do Amaral na pintura brasileira está na sua capacidade de dar, segundo ela, uma "cor local à sua obra, inventar formas e signos a partir das memórias de meninice e observação acurada da natureza" (FINAMBRÁS, 1998, p.9). Tarsila criou uma pintura pau-brasil. Como disse Oswald de Andrade, "ela foi quem ilustrou esta fase de 
apresentação de materiais, plasticizada por Di Cavalcanti, mestre de Portinari” (idem, p. 11). Uma artista brasileira que soube captar as cores de seu país, tropical, alegre e cordial. Da infância na fazenda, entre os cafezais e as paisagens de montanhas, mães pretas, gatos, livros e professores estrangeiros, até sua passagem pela França. Entre artistas e mestres, estudos e influências artísticas, ela potencializou seu aprendizado e transformou a arte brasileira, como ninguém antes o fizera. A arte de Tarsila é um marco na arte brasileira, porque trás a essência do seu povo e da sua cultura, grande mentora dos novos artistas que a sucederam.

As obras selecionadas de Tarsila do Amaral para trabalhar cidade e campo foram respectivamente E.F.C.B. (1924) e Paisagem com touro (1925). A conexão entre duas obras da mesma artista permitiu uma leitura diferente da primeira fase, até mesmo em relação a Da Vinci, cujas obras em duas técnicas diferentes, um desenho e uma pintura, e realizadas em diferentes fases da vida do artista. Neste caso eram duas pinturas com temas diferentes, pintadas pela mesma artista, no mesmo período, portanto com muitas semelhanças e contrastes de cores e formas.

A primeira é marcada, por uma composição quase geométrica. Em linhas pretas verticais e em "xiz" com fundo cinza formam pontes, torres, postes e sinalizadores, que sobrepostos às casas e à paisagem da cidade dão um clima de frieza e anonimato à vida urbana. O fundo em tom ocre, quase chapado, ocupa três quartos da obra como um chão de terra batida quase sem árvores; ao centro, a estação de trem cercada de estruturas; abaixo, dois "Ss" sugerem as linhas do trem e ao fundo uma vila de casas, sobrados e uma igreja separam o centro do bairro. Uma paisagem simétrica onde os elementos se equilibram como por uma força externa que mantém a ordem e o controle de um sistema.

$\mathrm{Na}$ segunda imagem, linhas curvas formam montanhas verdes com efeitos de luz e sombras e dão volume à obra. As casas se definem em diferentes planos e se compõem entre árvores e arbustos. O touro branco à frente da casa, também branca, sobre fundo amarelo, quase se perde na paisagem pelo baixo contraste entre a figura e o fundo, não fossem seus enormes chifres. $\mathrm{O}$ verde da paisagem transmite uma sensação de frescor e se contrapõe aos tons de ocre da cidade do quadro anterior. As formas curvas das montanhas, mesmo interrompidas pelas linhas retas das casas, transmitem uma sensação de paz e harmonia do campo.

Di Cavalcanti foi um pintor social militante, participou da Semana de Arte Moderna; um dos artistas brasileiros que melhor representaram a alma negra na pintura brasileira. "Uma 
das coisas mais importantes em Di foi a sua contínua preocupação em fazer uma arte brasileira, ligada aos aspectos cotidianos da vida brasileira e procurando através deles definir a nossa identidade cultural" (SCHENBERG, 1998). Dele selecionei as obras "Duas mulheres na varanda" (1961) e Paisagem de Subúrbio (1930), pois ambas indicam um ponto de vista de uma janela, embora a janela não esteja enquadrada na paisagem. A importância de Di Cavalcanti nesta etapa foi para mostrar como um artista brasileiro, sem negar sua origem negra, via a cidade e as pessoas que nela vivem; mestiços, mulatos, pessoas do povo são retratados no seu cotidiano, Di exagerava nas formas para realçar o tipo brasileiro, sua mestiçagem e seus gestos. A Paisagem do Subúrbio representa a periferia da cidade, uma realidade mais próxima dos alunos que se identificam com esta paisagem, hoje transformada por favelas que encobrem todo o morro e ocupam toda a área verde da cidade. Muros separam as casas e isolam as famílias, o espaço público desaparece. Estas obras devem dialogar com as imagens tanto da cidade como do campo, uma vez que a proposta é olhar pela janela e enxergar até onde as vistas alcançam. Ver o seu microespaço, o seu entorno e observar com atenção aquilo que sempre viu, mas nunca se apercebeu.

A escolha de René Magritte, para esta fase, foi pelo seu estilo surrealista ou "realismo mágico". Sua pintura brinca com a realidade, imagens insólitas com tratamento realista criam uma sensação de ilusão entre fenômenos opostos. Muitas das suas obras são enquadradas em janelas, e este enquadramento é importante para mostrar de que ângulo os educandos deveriam olhar para o mundo externo. A janela como uma metáfora da passagem de dentro para fora, mas não rigorosamente a paisagem vista lá fora, entre o fruidor da obra-de-arte e da paisagem real, há vários caminhos a escolher, e Magritte representa uma boa alternativa entre o real e o surreal para criação de metáforas visuais. Sua obra La clef dês champs é uma das obras contidas no calendário "Te Neues" 60 x 80. Impressas em excelente papel e qualidade de impressão, as obras são unidas por uma espiral com suporte prático para pendurar e expor. O calendário foi adquirido com a finalidade de utilização como recurso didático.

A paisagem da janela também aparece na obra de Henri Matisse, e seu estilo fauvista encantou as crianças pelas cores chapadas e fortes, contrastando entre si, sem perspectiva, uma característica da pintura infantil. Esta semelhança é uma forma de quebrar barreiras entre a arte e a produção artística da criança e do adolescente, sentindo-se mais seguros para realizar sua arte. As obras "Harmonia em Vermelho", de 1908, "Janela Aberta", de 1905 e "Janela em Tanger", de 1912, têm em comum a "janela", ora com fortes pinceladas ora com cores chapadas, a janela enquadrando a paisagem, ou no canto da sala onde a mesa e a parede 
se confundem no imenso vermelho; com vasinhos na janela e uma paisagem marroquina ao fundo, os detalhes serão ampliados pela ótica de quem irá apreciar, e aquele pequeno cavaleiro no canto do quadro poderá ser o tema escolhido para a representação da criança. As obras de Matisse apresentadas em sala de aula são outro calendário de Matisse da "Te Neues", de uma série adquirida como investimento para as aulas de arte.

As obras foram apresentadas com a música "Paisagem da Janela" de Milton Nascimento e com a poesia de Cecília Meireles; ambos descrevem com sensibilidade as belezas que vêm das janelas, num diálogo onde o outro não quer acreditar porque não consegue ver.

\subsection{Paisagem da janela na cidade}

$\mathrm{O}$ artista pode inspirar os educandos quanto a sua forma, cores e estilos, mas não houve nenhuma cópia de obra-de-arte, tão comum nas 'releituras' das obras de arte. Elas apenas serviram de inspiração para uma criação própria; quando isto ocorria havia um elemento na composição que o tornava único, como no caso do quadro de Magritte com o vidro quebrado, o aluno desenhou a janela quebrada por uma bola de futebol que atravessa a vidraça e caiu dentro da casa. A bola que compõe o quadro é sem dúvida uma característica própria do jovem brasileiro, apaixonado por futebol e, portando, muito significativo para o educando, no seu desenho. A influência de Magritte é visível, embora não seja cópia. De acordo com Ott, "quando o aluno está envolvido no ato de transformar, ele não copia ou simplesmente descreve a partir de uma obra, mas cria outra baseada nas percepções e compreensões que derivam ao observar obras no original” (BARBOSA, 1999, p. 124).

Nos desenhos e relatos, a sinceridade e a consciência da realidade vivida na cidade, e com naturalidade o jovem da cidade desenha prédios pichados e relata ao jovem do campo que da sua janela ele vê uma favela e desmente o estereótipo da mídia, dizendo que "lá tem gente boa não, tem só bandido". O relato de M. chama a atenção pela sua inteligência espacial, pela capacidade de desenhar. Enquanto eu apresentava a proposta ele desenhou e ao terminar a exposição o aluno apresentou sua atividade em forma de esboço, por não gostar de pintar seus desenhos deu por encerrada sua atividade. Diferente de outros alunos, seu desenho é bem elaborado, as linhas são livres e o espaço se compõe com equilíbrio e harmonia. A reclamação dos professores é que ele não pára na sala e constantemente seus pais são chamados na escola. Se para a escola ele é um problema que requer atenção e cuidado, em 
artes admiro-o pela rapidez e capacidade de síntese visual e objetividade, pouco valorizada na escola.

Outro aluno desenhou um muro, e atrás do muro dois prédios com cores gritantes que agridem a paisagem, e aconselhou seu correspondente a valorizar sua paisagem ampla e tranqüila do campo. Como deve incomodar abrir a janela diariamente e deparar com duas torres cor de abóbora na sua frente. Para este jovem nada é mais incômodo do que esta paisagem agressiva diante dos seus olhos. Os desenhos apresentados, na sua maioria, foram muito realistas, como nos verso de Caetano Veloso, as obras revelaram "a dura poesia concreta de duas esquinas", a cidade de São Paulo não poderia oferecer outra imagem senão essas.

Uma das alunas desenhou a fachada de um prédio de três andares e relatou sua relação com as famílias dos apartamentos, expressando seus sentimentos sobre cada uma das famílias. Como no filme de Hitchcock, Janela Indiscreta, ela assumiu o papel de voyeur ao descrever como vivem seus vizinhos. A descrição em detalhes de sua carta nos levar a entrar em cada apartamento, conhecer cada família e sentir-se parte da cena, para se ter uma idéia do hiperrealismo da paisagem. Houve quem se angustiasse diante do dilema de não verem nada além de um muro, então começaram a observar os fios da eletricidade, o poste da luz atrás do muro e até mesmo os trincos e as marcas do muro. Outros fizeram recortes e enquadramentos sem perspectiva, como Matisse, dando a impressão de uma composição geométrica das fachadas e garagens em frente de sua casa.

Enquadramentos entre o interior e o exterior da janela também foram apresentados. Recortes de sofás, móveis e lustres em primeiro plano se compõem com árvores, prédios e torres do lado externo da janela. Uma paisagem tipicamente urbana, mas não representa de modo algum a paisagem real vista da janela da casa do aluno, e sim uma montagem dos prédios e torres da Av. Paulista. Por ser uma atividade feita em casa, há dúvidas se esse desenho foi realmente elaborado pelo aluno.

O aluno E., com seu estilo mangá, desenhou uma paisagem enquadrada em uma janela estilo colonial com requintes de detalhes, mais que uma paisagem, uma cena de uma história, um story board, onde um carro de polícia persegue outro carro, deixando rastros no chão. Ele desenhou a esquina, as curvas de uma rua em declive, com perspectiva. Só com muito treino e perseverança um menino de 14 anos conseguiria chegar a esse nível de desenvolvimento técnico, e o ensino da arte na educação está muito aquém do seu grau de desenvolvimento. Se 
comparado com outros desenhos, podemos observar que há um grande desnível de qualidade entre os educandos.

Houve quem preferisse representar uma janela com cortinas estampadas, laços e uma paisagem com sol e casinhas, mas não foi por falta de repertório, foi por falta de vontade e comodismo, ou talvez por pura imaturidade. A avaliação em artes é uma questão delicada e difícil de ser equacionada. Só há três conceitos P, S e NS, Plenamente Satisfatório, Satisfatório e Não Satisfatório, respectivamente. A entrega da atividade pressupõe um conceito $\mathrm{P}$ e a não entrega até o final do bimestre NS, portanto o educando tem tempo suficiente para entregar suas atividades, porém muitos alunos passam o semestre sem fazer as atividades não só em artes como em todas as disciplinas.

\subsection{Paisagem da janela no campo}

A "Paisagem da Janela" foi apresentada a todos os grupos, assim como na primeira fase, e a participação foi quase unânime, tendo recebido desenhos e cartas das crianças, adolescentes, adultos e até dos mais idosos.

Todos se encantaram com a apresentação e a contextualização das obras, não havia tempo suficiente para que os participantes pudessem realizar as atividades logo em seguida às rodas de conversa, isto só foi possível com o grupo de adolescentes e com as crianças, especialmente com as turmas de $1^{\text {a }}$ e $2^{2}$ séries, às quais foram fotografadas para serem apresentadas em São Paulo.

Nos desenhos e nas cartas os relatos aproximam duas realidades tão desiguais e desconhecidas entre si e revela aos educandos uma diversidade cultural. Apesar do pouco tempo para aprofundar cada etapa, houve melhor qualidade nas apresentações, pois havia maior interesse e participação em cada encontro. Embora em circunstância diversa da sala de aula, porque eu representava para eles uma oportunidade única, uma pessoa estranha ao grupo que se apresentava como voluntária para propor uma nova atividade, e isto faz toda a diferença do ambiente escolar onde a professora está com os alunos durante todo o ano.

Os desenhos que levei da cidade foram distribuídos somente aos sem-terrinha, porque não imaginava que o projeto se ampliaria para grupos tão diversos, nem tampouco qual seria a reação dos educandos da cidade ao receber cartas de pessoas mais jovens ou mais velhas, e até 
de idosos. As paisagens das janelas eram reais e os relatos completavam o que talvez não tivesse ficado muito claro. "Da janela da minha casa eu vejo um pé de (....) e o meu cavalo" ou uma vaca. Uma sem-terrinha de 14 anos desenhou uma vaca sobre o muro depois de desenhar o que realmente via: "o muro da sua casa e a metade da casa do vizinho", como relata. Creio que não satisfeita com o primeiro desenho, ousou fazer uma imagem surreal, e antes de conhecer Magritte não arriscaria tal ousadia. Naquele período todas as casas estavam em reforma, pois estavam participando de um programa do governo para este fim. Um caso que beira o insólito foi um adolescente desenhar uma casa em construção e dizer na carta o que via. Na resposta, a alunada cidade diz: "Deve ser muito legal ver uma casa em construção.” Muito estranho, pois o que mais se vê em São Paulo são construções.

As cartas das turmas da $3^{\mathrm{a}}$ e $4^{\mathrm{a}}$ séries foram completadas com esse terceiro desenho, e anexadas. Após ler e analisar, os desenhos foram distribuídos aos alunos da cidade. Os educandos ficaram muito felizes ao receber as cartas de crianças reais, e um sentimento de solidariedade tomou conta da aula. Todos liam atentos as cartas da $3^{\mathrm{a}}$. e $4^{\mathrm{a}}$ série. As cartas dirigidas aos seus destinatários em São Paulo foram entregues em mãos e as demais foram distribuídas aos alunos. A reação de carinho e respeito foi muito grande, um sinal de generosidade por trás de uma falsa imagem de perversidade típica do adolescente.

\section{TERCEIRA FASE: ARTE E MEIO AMBIENTE}

Eu nasci neste mundo chamado natureza, Mas foi no Brasil que ela me provocou um grande impacto.

Eu a compreendi. Aqui eu nasci uma segunda vez, tomei consciência de ser homem E de participar da vida com muita sensibilidade, Meu trabalho, meu pensamento. Eu me sinto bem assim.

Frans Krajcberg

$\mathrm{Na}$ terceira fase da espiral do conhecimento, o objetivo da proposta Arte e Meio Ambiente foi sensibilizar o olhar para as questões ambientais. Saindo da dimensão do microespaço, referente à paisagem da janela, para o macroespaço, o educando irá deparar com uma realidade da qual pertence, mas não está só. As questões ambientais atingem a todos indistintamente; ricos e pobres, do campo e da cidade, crianças e idosos, todos são 
responsáveis, direta ou indiretamente, pelos danos causados ao meio ambiente e a arte cumpre este papel de denunciar, alertar, sensibilizar, atingir o ser humano pela emoção, uma vez que a ciência cumpre este papel pela razão.

Gutierrez, na década de 1990, criou a ecopedagogia, uma proposta pedagógica de cidadania ambiental global, com obrigações éticas entre a sociedade e os recursos naturais do Planeta para o desenvolvimento sustentável. "As pessoas e o planeta precisam ser salvos no mesmo projeto de futuro da humanidade" (GADOTTI ${ }^{43}$, apud GUTIERREZ et PRADO, 2000, p. 24). Para isso é preciso conscientizar todos os atores sociais da responsabilidade de cada um para com a vida no Planeta. Na mesma linha, Leonardo Boff, comprometido com a questão ambiental de forma contundente e incansável, fala das diversas formas do cuidado com a terra. (BOFF, 1999).

Uma forma de falar ao educando é articular o tema em diferentes linguagens, escrita, visual, auditiva, tátil e virtual. Os meios de comunicação e a web estão presentes em maior ou menor grau na vida do educando, e muitos têm maior facilidade com a linguagem virtual, fazem conexões com outros sites relacionados, uma linguagem relacionada com a própria realidade e menos com a escola. Pelo menos três conexões foram lançadas para provocar uma dissonância cognitiva no educando, desestabilizando-o de sua posição passiva para uma postura pró-ativa de participação no ensino da arte.

A conexão, Arte e Meio Ambiente, permitiu ao aluno articular arte com outras disciplinas, como ciências e geografia, um exercício aparentemente simples, mas muito difícil para o educando condicionado a uma aprendizagem compartimentada em disciplinas. Embora as abordagens sobre o meio ambiente sejam diferentes nas demais disciplinas, em geral, no ensino da arte, a questão ambiental limita-se à reciclagem, com o uso de embalagens para a criação de objetos e manipulação de materiais para criação. Neste caso, é preciso aprofundar a reflexão e conhecer outras manifestações artísticas diretamente relacionadas com os graves problemas ambientais tanto no campo como na cidade.

A segunda conexão foi estabelecer um vínculo entre o próprio educando e o planeta Terra, como co-responsável pelo destino do Planeta. O tema "Eu e Meu planeta", colocado na primeira pessoa, fala diretamente a cada um dos educandos, colocando-os no centro da questão ambiental, como co-responsáveis pelo destino do Planeta. Dessa forma, a resposta

43 Moacir Gadotti, como Diretor-Geral do Instituto Paulo Freire, faz a apresentação à edição brasileira do livro de Gutierrez - Ecopedagogia e Cidadania Planetária. 
antecede a pergunta: “O que eu tenho a ver com isto?" Tudo, afinal o planeta também é "Meu".

A terceira conexão está em relacionar os artistas e suas obras com a cidade e o campo, dois espaços separados geográfica e socialmente, porém com questões ambientais igualmente graves, como o desmatamento e as queimadas das florestas no campo e a poluição ambiental na cidade. Portanto, a questão ambiental permeia todos os espaços e atinge a todas as pessoas. O homem, na sua (ir)racionalidade, tem usado e abusado dos recursos naturais ao limite da saturação do Planeta, que já não se sustenta mais e dá sinais de esgotamento, com a morte anunciada pelo aquecimento global, as catástrofes naturais como tsunâmis, degelo dos pólos, vendavais, sem contar as doenças causadas ao ser humano provocadas por insetos, alimentos modificados e industrializados. Boff nos alerta: "Enfrentamos uma crise civilizacional generalizada. Precisamos de um novo paradigma de convivência que funde uma relação mais benfazeja para com a Terra e inaugure um novo pacto social entre os povos no sentido de respeito e de preservação de tudo o que existe e vive” (BOFF, 1999, p. 17-18).

Para dialogar com essas questões, dois artistas contemporâneos foram apresentados, Frans Krajcberg e Alexandre Órion, numa conexão entre a cidade e o campo, pois ambos exploram o tema arte e meio ambiente em seus diferentes significados, formas de expressão e representação. O primeiro, por sua incansável denúncia das queimadas das florestas brasileiras, e o segundo, pela sua proposta de arte menos poluição por meio da linguagem do grafite. Os recursos utilizados para a apresentação desses artistas foram livros, vídeo e informática. Na sala de informática, com a parceria da professora da sala, foi possível a apresentação dos artistas e suas obras de forma interativa e com recursos audiovisuais, seguidos de uma proposta de pesquisa e criação na internet.

Frans Krajcberg, polonês, 86 anos, está há mais de 60 no Brasil. Sua arte denuncia exaustivamente as queimadas das florestas brasileiras e transforma árvores calcinadas em 'monumentos', mais que esculturas, como forma de denúncia dos crimes ambientais pela devastação das florestas brasileiras em detrimento das futuras gerações.

Ventrella e Bortolozzo apresentam uma proposta interdisciplinar entre arte e ciência. A arte-educadora fala do artista e de sua obra e faz conexões com outras obras de arte, fala sobre a escultura do século XX; a segunda dialoga com o meio ambiente urbano, a monocultura, a floresta e a aldeia indígena. Segundo as autoras, "Krajcberg transformou sua 
arte em revolta e denúncia sobre o impacto causado pelas queimadas e desmatamentos que presenciou em nosso país” (VENTRELLA e BORTOLOZZO, 2006, p. 6).

O vídeo "O Poeta dos Vestígios", um documentário sobre o artista, relata sua trajetória desde sua vinda ao Brasil na década de 1950, até os dias de hoje, na luta pela vida das florestas e do mangue, por meio da arte. Krajcberg relata sua relação com a natureza, sua angústia pelos descasos ao meio ambiente e sua impotência diante da ganância dos homens e do sistema predatório de convivência com o Planeta. Em linguagem acessível, o vídeo apresenta imagens e processos de criação do artista, o uso dos materiais, e as técnicas ampliam as possibilidades de experimentar os recursos disponíveis na natureza para transformação em obras de arte.

Para contextualizar a questão ambiental com a cidade, apresentei uma 'intervenção urbana' realizada por Alexandre Órion; um jovem artista plástico de São Paulo, grafiteiro desde os 14 anos. Órion ocupou o Túnel Max Feffer em São Paulo por 16 dias, para retirar a fuligem dos carros impregnada nas paredes do túnel. Pelo processo de subtração, Órion desenhou um imenso conjunto de crânios humanos, em uma extensão de $160 \mathrm{~m}$, formando um verdadeiro "Ossário". Sua intervenção no espaço urbano é uma provocação não somente às autoridades, mas à sociedade em geral. Atendendo a uma denúncia, a polícia chegou ao local e sentiu-se impotente diante da ação do artista de 'limpar' desenhando crânios humanos, dizendo que a denúncia não procedia porque não se tratava de pichação, e sim de 'limpeza', e completa admitindo ser muito interessante.

Na manhã seguinte funcionário da Prefeitura foi ao local para lavar os crânios desenhados nas paredes do túnel, deixando uma extensão de $120 \mathrm{~m}$ do túnel sem lavar. $\mathrm{O}$ artista questionou se a ação da Prefeitura não seria uma forma de censura, e voltou ao local para continuar seu trabalho nos restantes $120 \mathrm{~m}$ do túnel, e persistiu em desenhar seus crânios até o final do túnel. A Prefeitura voltou ao local para lavar não só este túnel, como também todos os túneis da cidade. Sem a matéria-prima e o suporte para continuar sua obra, o artista deu por encerrada esta fase, mas levantou algumas questões, como "Melhor do que limpar seria não poluir" ${ }^{44}$. Alexandre Órion, por meio de uma linguagem artística urbana, o grafite, sensibiliza e questiona nossa contribuição para a poluição ambiental nas cidades. Ao comparar os dois artistas nas suas semelhanças e diferenças, conversamos e contextualizamos suas obras com a realidade de cada um. Esta obra despertou grande interesse nos educandos

44 Consultar o site do artista, disponível em: <http://www.alexandreorion.com> para assistir ao vídeo e às imagens do seu trabalho. 
por sua característica de grafite, pelo uso do espaço urbano, pela ousadia do artista. A identificação do artista foi maior principalmente com os meninos, pois sua arte simbolizava toda a ânsia de liberdade, coragem e rebeldia própria do adolescente.

\subsection{Arte e meio ambiente na cidade}

Após a apreciação da arte de Krajcberg, a proposta seria pesquisar materiais nos arredores da escola ou de sua casa e observar com olhos de artista e de cientista. Os alunos deveriam reconhecer como é o ambiente neste espaço, no sentido de uma percepção visual e tátil dos elementos naturais. Solicitei que fizessem anotações após visualizar e manipular os diferentes materiais encontrados no solo, constatando as diferenças e semelhanças entre eles. Pedi que observassem a forma e a textura, a dureza e o volume de pedras, cascas, folhas, raízes, sementes, flores, fibras e galhos e levar à escola. De volta à aula, socializamos as impressões, à luz das obras de Krajcberg, do que ele diz e pensa e das percepções do ambiente natural.

A proposta foi a criação de esculturas e maquetes em grupo com os materiais coletados, utilizando, se necessário, papelão, cola, arame e barbante para fixar os objetos e expor os trabalhos para que todos pudessem apreciar, debater as opiniões e refletir sobre as possíveis interpretações. Todas as etapas do processo seriam documentadas e descritas para seu correspondente. Houve um grande interesse por maquetes, especialmente pela casa na árvore de Krajcberg, e no dia seguinte os primeiros trabalhos chegaram já prontos de casa, esculturas em jornal pintado sobre madeira e terra, inspiradas na obra "Flor do Mangue", e maquetes da casa de Krajcberg deram um significativo movimento à escola no dia 5 de junho, Dia Mundial do Meio Ambiente.

Quanto à arte de Órion, estava diante de um desafio: Como transformar essa obra em produção artística no espaço escolar? Nesta fase havia planejado uma intervenção na escola como linguagem artística, mas como promover uma ação, sem tumultuar a escola?

A solução foi fazer uma intervenção na sala de aula, ou melhor, na própria carteira. Logo ao entrar na sala de aula, solicitei que guardassem todo o material, deixassem as carteiras desocupadas e ficassem apenas com uma borracha. Esta atitude provocou certo estranhamento, e após um profundo silêncio propus que desenhassem com a borracha sobre a carteira, retirando a sujeira. A atividade despertou grande interesse e teve uma participação 
unânime. As turmas que já tinham visto a apresentação de Órion na sala de informática, prontamente se puseram a desenhar, outras que ainda não tinham visto a apresentação não entendiam a proposta e gradativamente, ao ver um colega desenhando, percebiam que uma simples brincadeira havia se transformado em proposta artística; a ação havia se transformado em intervenção, ou seja, uma apropriação do universo lúdico para uma ação simbólica significativa. À medida que os desenhos apareciam eram todos fotografados e depois foram disponibilizados nos computadores, para serem identificados e manipulados digitalmente.

Nos desenhos, nos textos e nas falas, a proposta, além de despertar a atenção dos alunos, provocou uma reação contagiosa, ou seja, todos, um a um, aos poucos, se sentiam integrados à aula e espontaneamente procuravam se expressar, envolvidos pelo clima da classe e aderiam à proposta ${ }^{45}$. No intervalo, comentavam com colegas das outras classes e ao retornar, muitos já aguardavam ansiosos pela proposta. Esta foi sem dúvida a melhor avaliação da atividade, não apenas pelo desenho, mas pelo processo, sinergia e vibração da atividade, que embora individual, sentiam-se pertencer a um grupo coeso e integrado, cumprindo o principal papel da escola. É, como afirma Gutierrez, “a expressão criadora que torna possível o estabelecimento de um novo ambiente lúdico que dá segurança psicológica e ajuda a desenvolver o talento criativo e o respeito pelos outros". ${ }^{46}$

Ao relatar essa experiência ao artista, sensibilizado, Órion aprovou a proposta realizada em sala de aula, especialmente por ter escolhido a própria carteira, onde o educando tem uma relação diária com este espaço e também como equipamento público. Após a palestra, em conversa particular, ele sugeriu visitar a exposição "A Conquista do Espaço Novas formas da arte de rua", no Sesc Pinheiros, onde sua obra Ossário fora recriada no espaço e complementada com um vídeo sobre seu processo de trabalho após a intervenção urbana, cujo resíduo da fuligem recolhida no túnel transformou-se em matéria-prima, pigmento de uma tinta preparada para pintar um grande painel lá exposto.

Após uma visita individual para conhecer a exposição, divulguei aos alunos e apresentei os folhetos da exposição. Criou-se grande expectativa, porém a visita não se realizou por questões internas, gerando grande frustração nos educandos. Apresentei aos educandos o livro Metabiótica (ÓRION, 2007) referente ao outro projeto do mesmo artista, que escreveu a seguinte dedicatória: “À Edna, seus alunos do passado, do presente e do

45 Esta experiência foi relatada ao artista por ocasião de sua palestra no XVI COLE Congresso de Leitura e Escrita promovido pela ALB, na UNICAMP, em julho de 2007.

${ }^{46}$ Op.cit., p. 71. 
futuro, meu agradecimento por espalhar meu trabalho a outras cabeças. Um beijo do Órion”. A apreciação deste livro gerou tanto interesse que acabou por se estender por mais algumas aulas para uma atividade com a técnica de stêncil e possibilitou falar sobre a crônica como gênero literário e a crônica visual como uma nova linguagem artística.

\subsection{Arte e meio ambiente no campo}

Esta fase foi realizada com três grupos diferentes; educandos das $3^{\underline{a}}$ e $4^{\underline{a}}$ séries do ciclo I, adolescentes do assentamento e com o grupo de alfabetização de adultos. Para falar dos artistas, utilizei livros e o vídeo; sem computador, a apresentação das imagens de Alexandre Órion foi oral e pouco significativa, por se tratar de uma questão urbana, distante da sua realidade. A professora sugeriu passar as imagens em DVD.

Ao abrir o diálogo sobre o tema meio ambiente, as primeiras questões levantadas foram o desmatamento e o lixo produzido no assentamento. Problemas estes já contornados com soluções práticas como a preservação das nascentes de rios e a instalação de um biodigestor do lixo orgânico produzido no assentamento. O replantio de árvores nas margens do rio próximo ao assentamento foi realizado por toda a comunidade e envolveu as crianças e os adolescentes. Foi uma experiência significativa, pois além de acompanhar o crescimento das árvores, as crianças desenharam as árvores in loco, observando a natureza, e fizeram pinturas junto como casal M e P. Como diria Dewey, "o milagre da mente é que algo semelhante ocorre na experiência sem que haja transporte e sem disposição de ordem física. A emoção é a força que move e consolida" (DEWEY, p. 252).

Ao apresentar o artista Frans Krajcberg, todos ouviam muito atentos sua história e sua trajetória pelos Estados do Brasil, sua arte, os materiais e as técnicas utilizadas. Nas expressões de surpresa e curiosidade, o diálogo, a indignação e a consciência do papel da arte que extrapola a pintura e o desenho e transforma tudo em arte, até madeiras calcinadas, matéria-prima que o artista utiliza para expressar sua revolta contra a destruição das florestas brasileiras. A obra de Krajcberg apresentada aos educandos do campo amplia sua dimensão, é como semear em terreno fértil, uma arte significativa para quem o tema está presente no diaa-dia, pois o objetivo principal do MST é a agricultura sustentável, com preservação do meio ambiente contra o latifúndio e o agronegócio, que visam somente o lucro imediato em detrimento do meio ambiente e das futuras gerações. 
Atentos, os alunos assistiram ao vídeo "O Poeta dos Vestígios", fazendo pausas, quando necessário, para esclarecer ou acatar opiniões e comentários, e ao final da sessão, os alunos deveriam formar grupos e criar uma obra com os materiais encontrados no entorno da escola, inspirados nas obras de Krajcberg. Livres para criar, sem intervenção de adultos, os grupos saíram à procura de materiais, e apesar de conhecer bem o local, após conhecer a arte de Krajcberg, surgiu um novo olhar sobre cada material, mais atento e cuidadoso; uma pedra, não era mais uma simples pedra, ela tinha agora uma função, iria compor com outros materiais, para a criação de uma obra coletiva; juntos iriam decidir como e onde colocar os materiais recolhidos até formar uma obra única produzida pelo grupo. Envolvidos na pesquisa e no diálogo, acatando e respeitando as idéias de todos, aprenderam a importância da cooperação e o sentido do trabalho em grupo, compreenderam como as idéias se constroem coletivamente a partir do consenso. O senso estético surge espontaneamente, não há certo ou errado, há um imenso prazer e envolvimento na participação de todos, não estão preocupados com notas e conceitos; há o prazer de manipular e combinar materiais, tendo uma referência e um objetivo a atingir: apresentar sua obra concluída.

Após concluir a atividade, cada grupo apresentou aos demais grupos e explicaram, justificando o processo de criação e as relações com a obra do artista. Cada grupo se fixava em diferentes aspectos, encantados com a casa na árvore, ou impressionados com a monumentalidade de suas obras, ou com o gesto de sua expressão. De uma forma ou de outra, todos foram tocados pelo artista e se inspiraram nele para desencadear o processo de criação.

As flores e folhas foram os materiais mais presentes nas atividades, buscando um resultado estético não só inspirado na obra de Krajcberg, como também nas referências culturais acumuladas nas relações familiares e sociais. Um grupo se destacou pela organização e pelo resultado apresentado. Utilizando uma variedade de materiais, eles construíram uma casa com área demarcada por pedras brancas e um arco para demarca o portal de entrada. Alguns elementos podiam ser associados às imagens do filme, como a entrada na casa de Krajcberg, o tronco representando uma escultura, mas esta instalação remete ao concurso de arte-educação do MST: "Como fazer a escola, transformando a história". Ao construir uma nova escola, mais democrática e participativa com respeito ao protagonismo, tão urgente e necessária não só nas escolas do MST, mas na educação em geral. 
O grupo de alfabetização de adultos também assistiu ao vídeo e se indignou com o que viu. Após uma roda de conversa sobre o tema, arte e meio ambiente, apresentação do artista, sua obra e o vídeo, houve uma participação ativa e até os mais tímidos fizeram suas críticas à irracionalidade humana e, em seguida, combinaram de se encontrar no dia seguinte na horta de ervas medicinais para realizar a atividade proposta.

No dia seguinte, as alunas me chamaram na escola para apreciar a produção coletiva na horta. No local encontrei uma cabana de lona preta com uma bandeira e sob a cabana, uma composição com panelas e enxadas. Os elementos reunidos representavam um gesto simbólico de toda a história de luta e resistência até chegar ao ponto onde se encontram hoje. Longe do ideal, mas com uma auto-estima elevada, esta instalação, trás na sua essência um sentimento comum entre o artista e o grupo, vivido e resgatado na memória de cada um e expresso por meio dos elementos simbólicos utilizados.

O terceiro grupo, dos adolescentes, não realizou a instalação, porque neste dia não foi possível acompanhá-los por estar com as turmas de $1^{\mathrm{a}}$. e $2^{\mathrm{a}}$. série. Sugeri aos adolescentes que observassem as instalações espalhadas pela agrovila e do grupo de alfabetização. O grupo de EJA também não realizou esta atividade.

\section{AVALIAÇÃO DO PROJETO}

O projeto desenvolvido durante o ano letivo de 2007 traz algumas lições. Esta experiência permitiu aproximar os educandos da cidade com os educandos do campo desconhecidos para eles, assim como a realidade de quem vive no Movimento. Os alunos escreveram e leram as cartas, se emocionaram, compartilharam seus sentimentos com educandos do campo e isto trouxe uma dinâmica diferente às aulas e uma nova motivação, mas este projeto, para ser viável, deve ser uma ação dentro do projeto pedagógico da escola que ao se cadastrar no projeto Escolas Irmãs do Governo Federal e indicar o perfil da escola que procura, o MEC indicará uma escola indígena, de quilombo ou do campo e de comum acordo com o Conselho de Escola, as escolas passam a se conhecer através de cartas e vão além, promovem ações de cidadania e solidariedade como campanhas de arrecadação de livros para formação de bibliotecas nas escolas do campo e outras iniciativas de solidariedade como exercício de cidadania. 
O projeto de ensino da arte, dividido em três etapas forneceu um grande material de pesquisa para um ano letivo e deveria se concentrar no aprofundamento dos conteúdos a serem trabalhados. Um programa de curso com objetivos claros e metas definidas facilita a comunicação e incentiva a pesquisa dos educandos que têm clareza do caminho a ser percorrido e isto é possível com um bom planejamento em arte. A troca de correspondências foi um projeto paralelo ao programa de artes e no decorrer do ano, as ações não aconteciam conforme o planejado, criando um descompasso entre uma etapa e outra e entre o campo e a cidade.

O intercâmbio cultural no ensino da arte é viável com a parceria entre os educadores de ambas as comunidades escolares com um planejamento e objetivos comuns. O papel do educador, no intercâmbio é de mediador das ações realizadas pelos educandos na sua comunidade escolar. A experiência de ensino da arte na cidade e no campo permitiu conhecer simultâneamente duas realidades diferentes, mas não serviu de parâmetro para avaliação pelas condições adversas e contextos diferentes.

Esta pesquisa não esgota o tema e contribuiu para fazer um levantamento de dados para estudos futuros. Os dados coletados são referenciais para dar continuidade a projetos a serm desenvolvidos.

O contato com o MST permitiu conhecer uma comunidade integrada e disposta a estudar, uma comunidade que se transforma rapidamente. Em um ano as transformações e as conquistas na educação foram visíveis na agrovila III, como o curso de EJA junto à Secretaria de Educação, o programa de alfabetização de adultos e a reforma da escola. O contato com as crianças do ciclo I representou um grande aprendizado e demonstrou a importância do ensino da arte no ciclo I. Os educandos são muito receptivos e correspondem às atividades propostas. São muito rápidos e querem produzir muito, principalmente os mais novos que termimam suas atividades e pedem mais, nesta fase, na minha avaliação, os educandos estão descobrindo, experimentando; um potencial a ser explorado com varidade e diversidade de materiais, imagens e recursos disponíveis, estão na fase concreta e quanto mais materiais para manusear e experimentar melhor para o seu desenvolvimento.

Os adolescentes são ativos e espontâneos criam quando estão motivados e se desinteressam facilmente, são muito expostos à mídia e reproduzem modelos estereotipados, 
daí a importância da arte para oferecer um repertório cultural que faça um contraponto às imagens midiáticas.

$\mathrm{Na}$ Educação de Jovens e Adultos, a produção artística não flui tão facilmente, o aquecimento é um momento importante para preparar o educando e envolvê-lo na proposta. É preciso dar mais tempo e acompanhar o ritmo do grupo. São mais reflexivos, falam pouco mas analisam cada gesto, cada palavra proferida. A produção artística reflete muito suas histórias pessoais que emergem nos detalhes e nas linhas.

Esta pesquisa permitiu compartilhar com os educandos uma experiência de ensino da arte através do diálogo entre os educandos da cidade e do campo nos diferentes níveis de escolaridade e faixas etárias, uma experiência significativa que poderá contribuir para futuros projetos e novas pesquisas. Aprendi também com as falhas e com os "acidentes de percurso", que foram solucionados à medida que surgiam, conforme as condições disponíveis em cada momento. 
Ao iniciar esta pesquisa não conhecia nada sobre educação do campo, um campo da educação cujo acesso sempre foi negado ou ignorado pelo sistema dominante, seja nos cursos de pedagogia ou de arte-educação. Até mesmo em concursos públicos nunca houve uma bibliografia específica sobre educação do campo. A pesquisa abriu as portas desta área desconhecida e mostrou que o campo está vivo, produz intensamente e já colhe seus frutos, uma área que é objeto de muitas pesquisas acadêmicas que comprovam sua legitimidade e a capacidade de transformação.

Quanto ao ensino da arte na educação formal, nas escolas do MST os educadores em geral, desconhecem a dinâmica do Movimento que acontece paralela à escola, o aprendizado da arte para os Sem Terra está na Pedagogia da Cultura do Movimento, ou seja, nas músicas, nas brigadas de teatro, nos murais produzidos, individual ou coletivamente, e principalmente nas místicas, aquele momento tão aguardado e preparado especialmente para aquele evento (festa, encontro, curso, seminário, assembléia, congresso ou marcha). A mística está no limite entre a arte e a espiritualidade, é o momento da transcendência para uma dimensão mais elevada, na mística todos se transformam em uma só unidade e renovam-se em comunhão.

A mística é a "experiência estética" a que se referia Dewey, prática e vivida, é a experiência consumatória proposta por Dewey (BARBOSA, 1989, p. 109), subutilizada por Teixeira na Escola Nova e ressignificada por Ana Mae na abordagem triangular (BARBOSA, 1991, p. 10). Desde a preparação de uma mística, a pesquisa, a contextualização com o tema e com o público, a preparação e a apresentação, em todas as etapas há um grande envolvimento e entrega total para uma apresentação tão fugaz quanto profunda e significativa, uma experiência que só a arte pode proporcionar.

O 6o Concurso de Arte-Educação do MST deverá apontar novos caminhos para o ensino da arte do Movimento, uma proposta que sairá de baixo para cima. A partir dos trabalhos apresentados, das propostas e dos textos, serão extraídas as diretrizes de uma proposta para o ensino da arte. Gostaria de trazer os resultados do concurso neste trabalho, o que não ocorreu a tempo, mas seja qual for o resultado, será muito gratificante para o ensino da arte no País.

$\mathrm{Na}$ educação da cidade onde atuo profissionalmente, a escola, objeto da pesquisa, passou por mudanças repentinas de um ano para o outro, reduzindo turnos e perdendo a sala de artes e a sala de vídeo para se transformarem em salas de aula, agravado pela falta da 
diretora, que estava de licença médica, e por mim mesma, que não conhecia a comunidade escolar. Seu projeto pedagógico não refletia a realidade da escola e não atendia aos anseios da comunidade, a escola revelava-se mais no seu currículo oculto, manifestado na revolta e no vandalismo dos educandos pela indiferença e pelo autoritarismo da equipe técnica.

O ensino da arte na escola da cidade deveria conciliar os parâmetros curriculares com os referenciais de arte para o ensino fundamental II para o ano letivo de 2007, tendo a leitura e a escrita prioridade máxima. Para atender a esta prerrogativa, desenvolvi uma proposta de arte-educação que integrasse a leitura e escrita gráfica e literária com a leitura e escrita visual. Os educandos dessa escola sempre tiveram a mesma professora, desde a $5^{\text {a }}$ até a $8^{\mathrm{a}}$ série. Ao assumir as aulas, tive que conquistá-los para conseguir desenvolver a proposta. A motivação dos alunos para a realização do projeto foi a possibilidade para eles se corresponderem com outro educando que eles não conheciam.

Estava tudo planejado para dar certo, conhecia a escola que atendia aos educandos do assentamento, conhecia a diretora, conversei com a professora de artes enviei o projeto e iniciei o projeto na cidade. Ao enviar as cartas, não obtive o retorno, então viajei até o assentamento e constatei que o projeto não se viabilizaria nessa escola. O projeto se viabilizou na escola da Agrovila III do ciclo I e EJA, graças ao apoio da diretora e arte-educadora que, aberta à proposta, incentivou as professoras a implantar o projeto com seus alunos. Descobri afinal o quanto a pesquisa cresceu no contato com grupos tão heterogêneos, na idade e na escolaridade. O intercâmbio cultural foi uma experiência nova e não poderia imaginar os rumos que esta experiência tomaria ao se ampliar para outros segmentos, e ampliar-se para outras faixas etárias e níveis de escolaridade.

Através da arte, o educando da cidade ao se corresponder com o educando do MST, conheceu e dialogou com educandos do campo. Ao responder as cartas com carinho e respeito tanto para as crianças como para os mais idosos, os educandos da cidade revelaram seu lado humano e solidário como diz Martins:

a linguagem da arte nos dá a ver o mundo mostrando-o de modo condensado e sintético, através de representações que extrapolam o que é previsível e o que é conhecido. É no modo de pensamento do fazer da linguagem artística que a intuição, a percepção, o sentimento/pensamento e o conhecimento se condensam (MARTINS et al., 1998, p. 46). 
No papel de mediadora deste projeto, não medi esforços para atender o cronograma e as demandas que surgiam no dia a dia, mas esta não foi a melhor solução, o ideal seria envolver os educadores das duas comunidades e desta troca compartilhada de experiências, promover uma educação mais solidária e cidadã como propõe o programa Escola Irmãs.

O esforço de viabilizar o projeto, ao assumir a responsabilidade de coordenar a complicada logística de preparar as aulas, tanto para a sala de aula com para a informática; ler, fotografar, registrar, documentar, levar e trazer cartas e desenhos de ambas as comunidades e distribuí-los aos seus destinatários, Estas ações simultâneas levaram a uma distorção do objetivo principal deixando escapar importantes ações específicas do ensino da arte que não poderiam acontecer.

O aprendizado através dos erros ajuda a refletir e repensar novas formas de realização e a experiência tornou-se significativa ao trazer elementos para esta reflexão. Sinto-me gratificada pela articulação e produção do projeto e por ter compartilhado com tantas pessoas, tão diferentes entre si, e socializado o conhecimento que poderia estar restrito ao dia-a-dia na sala de aula. 


\section{BIBLIOGRAFIA}

ALVES, R. A escola que sempre sonhei sem imaginar que pudesse existir. Campinas-SP: Papirus, 2001.

. Conversas com quem gosta de ensinar. São Paulo: Cortez, 1993.

ALMEIDA, L.F. de e SÁNCHEZ, F. R. Um grão menos amargo das ironias da história: o MST e as lutas socais contra o neoliberalismo. Lutas sócias 5. São Paulo: PUC/NEILS, $2^{\circ}$ semestre de 1998, p.77-93.

ARROYO, M. Trabalho - educação e teoria pedagógica in FRIGOTTO, G et al. Educação e crise no trabalho: perspectiva do final do século. Petrópolis, RJ: Vozes, 2001. 5. ed.

, CALDART, R.S.; MOLINA, M.C. (Org.) Por uma educação do campo.

Petrrópolis, RJ: Vozes, 2004.

ARNHEIM, R. Arte e percepção Visual. São Paulo: Martins Fontes, 1980.

. Intuição e intelecto na arte. São Paulo: Martins Fontes, 1989.

BARBOSA, A.M. A arte na educação do MST. Revista Digital Art\&n. 4 out.2005. Disponível em <http://www.revista.art.br/site-numero-04/apresentacao.htm>. Acesso em: 20 set. 2006.

. O MST e as artes [mensagem pessoal]. Mensagem recebida por anamae@uol.com.br em 30 set. 2006.

. A imagem no ensino da arte. São Paulo: Perspectiva/IOCHPE, 1991.

. Arte-educação no Brasil: do modernismo ao pós-modernismo. Revista Digital

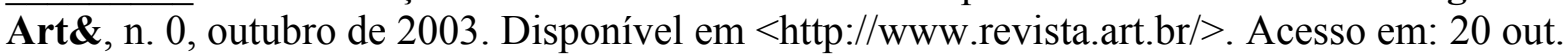
2006.

. Arte-educação: Conflitos/acertos. São Paulo: Max Limonad, 1984. 188 p.

. (Org). Arte-educação: Leitura de subsolo. São Paulo: Cortez, 1997.

. (Org). De olho no MAC. São Paulo: MAC-USP, 1992.

. História da arte-educação. São Paulo: Max Limonad, 1984.

. Inquietações e mudanças no ensino da Arte. São Paulo: Cortez, 2002.

. Recorte e colagem: Influência de John Dewey no ensino da arte no Brasil. São

Paulo: Autores Associados, Cortez, 1982. 136 p. 
. Teoria e prática da educação artística. São Paulo: Cultrix, 1975. 115 p.

. Tópicos utópicos. Belo Horizonte: C/Arte, 1998.

. Prefácio. In: O Museu de Arte Contemporanea da Universidade de São

Paulo. Prefacio de Ana Mae Tavares Bastos Barbosa, coordenação de Maria Izabel Branco Ribeiro. Sao Paulo: Banco Safra, 1990. 319 p.

1990.

; SALES, H.M. (Org.). O ensino da arte e sua história. São Paulo: MAC/USP,

BARON, D. Alfabetização cultural - A luta íntima por uma nova humanidade. São Paulo: Alfarrábio, 2004.

BERGER, C.L.C. Campos em confronto: Jornalismo e movimentos sociais. As relações entre o Movimento Sem-Terra e a Zero Hora. Tese de doutorado defendida na ECA USP em maio de 1996. Disponível em < http://bocc.ubi.pt/pag/berger-christa-campos-0.html acesso em 20/5/2007> acesso em 15 jul 2006

Campos em Confronto: A Terra e o Texto. Porto Alegre: Editora da Universidade/UFRGS, 1998.

BOFF, L. A águia e a galinha: uma metáfora da condição humana. Petrópolis-RJ: Vozes, 1997.

.Biografia. Disponível em: <http://www.fly.to/Boff>. Acesso em: 20 jun. 2007.

. Teologia. Disponível em: <http://www.leonardoboff.com/site/teo/teo.htm>.

Acesso em: 20 out. 2007.

. Saber cuidar: ética do humano, compaixão pela terra. Petrópolis:Vozes, 2001.

BOGO, A. O vigor da mística. São Paulo: MST, 2002.

. Lições da luta pela terra. Salvador: Memorial das Letras, 1999.

BORDIEU, P. Os excluídos do interior. In: NOGUEIRA, MA e CATANI, A (Org).

Bourdieu: escritos de educação. 6. ed., Petrópolis: Vozes, 2004, p. 217-228.

BOSI, A. Fenomenologia do olhar. In: NOVAES, A. (Org.). O olhar. São Paulo: Cia das Letra, 1988, p. 68-73.

BRASIL. Parâmetros Curriculares Nacionais (5a $\mathbf{8}^{\mathbf{a}}$ series). Terceiro e quarto ciclos do ensino fundamental: Artes. Brasília: MEC/SEF, 1998.

BUORO, A.B. Olhos que pintam: a leitura da imagen no ensino da arte. São Paulo: Educ/Fapesp/Cortez, 2002. 
. O olhar em construção - Uma experiência de ensino e aprendizagem da arte na

escola. 3. ed., São Paulo: Cortez, 1998,

CALDART, R.S. Pedagogia do Movimento Sem-Terra. 3. ed., São Paulo: Expressão Popular, 2004.

. Sem-terra com poesia. Petrópolis: Vozes, 1987.

. O MST e a formação dos Sem-Terra: o movimento social como princípio

educativo. Estudos avançados, São Paulo, v. 15, n. 43, set./out., 2001.

CAMPOS, H. Crisantempo. São Paulo: Perspectiva, 1998

CAPRA, F. O ponto de mutação: a ciência, a sociedade e a cultura emergente: São Paulo Cultrix, 1982.

CARVALHO, R. E. Educação inclusiva: com os pingos nos "is". Porto Alegre: Mediação, 2004.

COLI, J. O que é arte. São Paulo, Brasiliense, 2004.

. Por um olhar atento e lento. São Paulo-SP. Carta Capital, n. 10, p. 6-9, out. 2006 (entrevista concedida à revista Carta na Escola).

DEWEY, J. Arte como experiência. São Paulo: Abril Cultural, 1974, p245-63 (Col. Os Pensadores, v. 40).

El arte como experiência. México: Fondo de Cultura Economica, 1949.

D’AMBRÓSIO, Ubiratan. Conhecimento e Consciência: O Despertar de Uma Nova Era in Guevara, Arnoldo J. H. ET ali. Conhecimento Cidadania e Meio Ambiente. São Paulo, Peirópolis, 1998.

FREINET, Celestin. Pedagogia do Bom Senso. São Paulo, Martins Fontes,1991.

FAZENDA, I. Interdisciplinaridade: um projeto em parceria. São Paulo: Loyola, 1991.

FELDMAN, E.B. Art as image and idea. Englewood Cliffs: Prentice Hall, 1981a.

. Becoming human though art, an esthetic experience in the school. Englewood Cliffs: Prentice Hall, 1970.

. Varieties of visual experience. Englewood Cliffs: Prentice-Hall, 1981b. 
FERNANDES, B.M.; STEDILE, J.P. Brava gente - A trajetória do MST e a luta pela terra no Brasil. São Paulo: F. Perseu Abramo, 1999.

. Questão agrária, pesquisa e MST. São Paulo: Cortez, 2001.

et al. Assessoria ao MST. I Congresso de Extensão Universitária, Seminário

Reforma agrária e trabalho rural. Presidente Prudente, SP. Disponível em: $<$ http:// http://proex.reitoria.unesp.br/congressos/Congressos/1_Congresso/Reforma_

_Agr_ria_e_Trabalho_Rural/Trabalho01.htm>. Acesso em: 12 dez. 2007.

. O MST, sua genealogia e a luta pela reforma agrária no Brasil - a formação do MST. Banco de dados preparado por Else P. Vieira. In Imagens e vozes da despossessão: a luta pela terra e a cultura emergente do MST. no ar desde 2003. Disponível em:< http://www.landless-voices.org/vieira/archive-05.phtml?

$\mathrm{rd}=$ MSTITSSG356\&ng $=\mathrm{p} \& \mathrm{sc}=3 \& \mathrm{th}=42 \& \mathrm{se}=0>$ Acesso em 20.10.2006.

.Pequeno vocabulário da luta pela terra. Banco de dados preparado por Else P. Vieira. In Imagens e vozes da despossessão: a luta pela terra e a cultura emergente do MST. Cultura emergente por categoria - assentamentos: educação: no ar desde 2003. Disponível

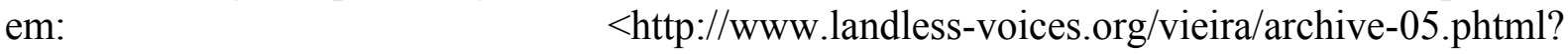
$\mathrm{rd}=$ PERFMYST001\&ng $=\mathrm{p} \& \mathrm{sc}=2 \& \mathrm{th}=17 \& \mathrm{se}=0>$. Acesso em 12 jun. 2006.

FERRAZ, M.H.C.T. et FUSARI, M.F.R.; Metodologia do ensino da arte. São Paulo: Cortez, 1999.

. Arte na educação escolar. São Paulo: Cortez, 1992.

FOUCAULT, M. Vigiar; punir. Rio de Janeiro: Vozes, 2000.

. Microfísica do poder. Rio de Janeiro: Graal Editora, 2003.

FRANCASTEL, P. A realidade figurativa. São Paulo: Perspectiva, 1993

FREIRE, M. A paixão de conhecer o mundo: relatos de uma professora. Rio de Janeiro: Paz e Terra, 1983.

et al. Estudo do meio. In: Instrumentos metodológicos II. Avaliação e planejamento: a prática educative em questão. São Paulo: Espaço Pedagógico, 1997. p.17-8.

FREIRE, P. A educação na cidade. São Paulo: Cortez, 1991.

A importância do ato de ler em três artigos que se completam.. São Paulo: Cortez, 2001. 42 ed.

Cartas à Guiné-Bissau - Registros de uma experiência em processo. Rio de Janeiro: Paz e Terra, 1976. 
. Carta à Guiné Bissau a Mário Cabral in Paulo Freire - um educador do povo.

São Paulo: ANCA, 2005.

Carta aos professores in Paulo Freire - um educador do povo. São Paulo:

ANCA, FNDE, 2005.

Paulo Freire - um educador do povo ANCA/FNDE. São Paulo, ANCA, 2005. p. 40 (Transcrição do depoimento de Paulo Freire gravado em novembro de 1996).

Pedagogia da autonomia, saberes necessários à prática educativa. São Paulo: Paz e Terra, 1996.

Pedagogia da esperança, um reencontro com a pedagogia do oprimido. Rio de Janeiro: Paz e Terra, 1992.

. Pedagogia do oprimido. 14. ed., Rio de Janeiro: Paz e Terra, 1983.

1993.

. Professora sim, tia não. Cartas a quem ousa ensinar. São Paulo. Olho D’Água,

FREIRE, P; FAUDEZ, A. Por uma pedagogia da pergunta. Rio de Janeiro: Paz e Terra, 1985.

FREIRE, P.; MACEDO, D. Alfabetização. Rio de Janeiro: Paz e Terra, 1994.

FREIRE, P.; SHOR, I. Medo e ousadia. Rio de Janeiro: Paz e Terra, 1986.

GADOTTI, M. Pedagogia da terra. 4. ed., São Paulo: Petrópolis, 2000.

GARDNER, H. As artes e o desenvolvimento humano. Porto Alegre: Artes Médica, 1997.

Estrutura da mente: a teoria das inteligências múltiplas. ArtMed: Porto Alegre, 1994.

. Inteligências múltiplas: a teoria na prática. Porto Alegre: Artmed, 1994.

GELB, M.J. Aprenda a pensar com Leonardo da Vinci - Sete passos para o sucesso no seu dia-a-dia. São Paulo: Ática, 2000.

GOHN, Maria da Glória. Educação não formal e cultura política: impactos sobre o associativismo do terceiro setor. São Paulo, Cortez, 1999. - (Coleção Questões da nossa época; v.71).

GUTIÉRREZ, Francisco; PRADO, Cruz. Ecopedagogia e Cidadania Planetária. São Paulo: Cortez, 1999. 
HART, T. Crianças famosas: Leonardo da Vinci. São Paulo: Callis, 1994.

HERNÁNDEZ, F. Cultura visual, mudança educative e projeto de trabalho. Porto Alegre: Artmed, 2000.

. Transgressão e mudança na educação: os projetos de trabalho. Trad. Jussara Haubert Rodrigues. Porto Alegre: Artmed, 1998.

HENRIQUE, M. e VASCONCELOS NETO. Terra, Mística Vida! Apresentação do depoimento de D. Tomás Balduíno em vídeo. Disponível em: < http://www.youtube.com/watch?v=toitTQNcbJk>. Acesso em: 15 dez. 2007.

GRANMA INTERNACIONAL. Unesco entrega a Cuba prêmio de alfabetização 2006. Disponível em <http://www: granma.cu/portugues/2006/noviembre/lun6/46entrega-p.html> acesso em 18.set.2007.

ITERRA. Curso normal: projeto pedagógico. Cadernos Iterra, Veranópolis-RS, ano IV, n. 10, dez. 2004.

Pedagogia da terra. Cadernos Iterra, Veranópolis-RS, ano II, n. 6, dez. 2002.

KLEIMAN, A; MORAES, S.E. Leitura: ensino e pesquisa. Campinas: Pontes, 2001.

. Leitura e interdisciplinaridade: tecendo rede nos projetos de escola. Campinas:

Mercado das Letras, 1999.

. Texto e leitor: aspectos cognitivos da leitura. Campinas: Pontes, 2002.

KOLLING, E. J.; CERIOLI, P.R.; CALDART, R.S. (orgs.). Educação do Campo: Identidade e Políticas Públicas, Brasília, DF: articulação nacional Por Uma Educação no Campo, 2002. Coleção Por Uma Educação do Campo, no 4.

KOUDELA, I.D. Brecht na pós-modernidade. São Paulo: Ed. Perspectiva, 2001

. Brecht: um jogo de Asprendizagem. São Paulo: Edusp/Perspectiva, 1992.

. Jogos Teatrais. São Paulo, Perspectiva, 1984.

. Texto e jogo. São Paulo: Fapesp/Perspectiva, 1996.

. Um vôo brechtiano. Teoria e prática da peça didática. São Paulo:

Fapesp/Perspectiva, 1992.

LANGER, S.K. Sentimento e forma. São Paulo. São paulo : Perspectiva, 1980. 
LEUDERMANN, C.S. Anton Makarenko vida e obra - a pedagogia na revolução. São Paulo: Expressão Popular, 2002. 432 p.

MACHADO, R.S. Acordais - fundamentos teórico-poéticos da arte de contar histórias. São Paulo: DCL, 2004.

Leituras de obras de arte e discussão acerca do lugar da apreciação na sala de aula de acordo com os Parâmetros Curriculares Nacionais. São Paulo: Sesc SP, 1998.

MANGUEL, A. Lendo imagens. São Paulo: Cia. Das Letras, 2001.

MIGUEL FRIAS \& ASSOC. A coleção Constantini no MAM. Buenos Aires: Cochrane, 1988

MEC. Programa Escolas-Irmãs Todos tem algo a ensinar e a aprender! Disponível em $<$ http://portal.mec.gov.br/arquivos/pdf/escolasirmas.pdf $>$ acesso em 06 mai 06

MARTINS, M.C. Não sei desenhar: implicações no desvelar/ampliar do desenho na adolescência. 1992. 373f. Dissertação (Mestrado) em 1992 - Escola de Comunicação e Arte, Universidade de São Paulo, São Paulo, 1992.

MORISSAWA. M. A história da luta pela terra e o MST. São Paulo: Expressão Popular, 2001.

; PICOSE, G.; GUERRA, M.T. Didática do ensino da arte. A lingual do mundo: poetizar, fruir e conhecer arte. São Paulo: FTD, 1998.

MERLEAU-PONTY, M. A prosa do mundo. São Paulo: Cosac \& Naify, 2002.

MOLINA, M.C.; JESUS, S.M.S.A. (Org.) Contribuições para a construção de um projeto de educação do campo. Coleção por uma Educação do Campo, n. 5. Articulação Nacional por uma Educção do Campo (Unicef, UNB, Unesco, MST, CNBB): Brasília, DF, 2005.

MORIN, E. Ciência com Consciência. Rio de Janeiro: Bertrand Brasil, 2002.

et al. in Entrevistas do Le Monde. São Paulo: Ática, 1989.

. Os Sete Saberes Necessários à Educação do Futuro. São Paulo: Cortez; Brasília, DF: UNESCO, 2006.

MST. Agenda 2006. São Paulo: MST, 2006.

. Cartaz da Campanha Nacional de Alfabetização de Adultos do MST. Disponível e. $<$ MST.org.br $>$ acesso em 18 set. 2007.

. Dossiê MST escola: caderno de educação n.13 edição especial. São Paulo: Expressão Popular, 2005. 
. MST. O funcionamento das brigadas do MST. São Paulo: MST, 2005

NOVA CULTURAL. Os grandes artistas - Romantismo e Impressionismo - Degas, Toulouse-Lautrec e Monet: São Paulo: Nova Cultural, 1991.

. Os grandes artistas - Romantismo e Impressionismo Van Gogh, Renoir e Manet: São Paulo: Nova Cultural, 1991.

OLIVEIRA, A.C. Convocações multissensoriais da arte no século XX. In: PILLAR, A.D. (Org.). A educação do olhar no ensino das artes. Porto Alegre: Mediação, 2001.

ÓRION, A. Metabiótica = metabiotics. São Paulo: Via das Artes, 2006

OSTROWER, F. Acasos e criação artística. Rio de Janeiro: Campus, 1998. . Criatividade e processos de criação. Petrópolis: Vozes, 1997.

OTT, R.W. Ensinando crítica nos museus. In: BARBOSA. A.M. (Org.) Arte-educação: leitura no subsolo. São Paulo: Cortez, 1997, p. 111-39.

PANOFSKY, E. Significado nas artes visuais. São Paulo: Perspectiva, 1979.

PAREYSON, L. Os problemas da estética. São Paulo: Martins Fonetes, 1989.

PARSONS, M. J. Compreender a arte. Tradução Ana Luisa Faria. Lisboa: Presença, 1992.

. Mudando direçõs na arte-educação contemporânea. Palestra proferida no Serviço Social do Comércio (Sesc), São Paulo, 1998

PENNA, M. PCN nas escolas: e agora? Artigo disponível em: $<\mathrm{http}: / / \mathrm{www}$. artenaescola.org.br//pesquise_artigos_texto.php?id_m=12>. Acesso em: $20 \mathrm{dez}$. 2007.

PILLAR, A.D. (Org.). A educação do olhar no ensino das artes. Porto Alegre: Mediação, 1999.

PISTRAK, M. Fundamentos da escola do trabalho. 4. ed., São Paulo: Expressão Popular, 2005. 224 p.

RIZZI, M.C.S. Caminhos metodológicos. In: BARBOSA, A.M. (Org.). Inquietações e mudanças no ensino da arte. São Paulo: Cortez, 2002.

RODRIGUES, A.D. A imagem e o texto. In: Comunicação e cultura - a experiência cultural na era da informação. Lisboa: Presença, 1999. p.121-7. 
ROSSI, M.H.W. Imagens que falam - leitura da arte na escola. Porto Alegre: Mediação, 2003.

SALGADO, S. Terra. São Paulo: Cia. das Letras, 1997.

SÃO PAULO. Secretaria Municipal de Educação. Diretoria de Orientação Técnica.

Referencial de expectativas para o desenvolvimento da competência leitora e escritora no ciclo II no Ensino Fundamental. São Paulo: SME/DOT, 2006.

. Referencial de expectativas para o desenvolvimento da competência leitora e escritora no ciclo II: Caderno de Orientação Didática de Artes. São Paulo: SME/DOT, 2006.

SERCUNDES, M.M.I. Ensinando a escrever. In: GERALDI, J.W.; CITELLI, B. (Coord.). Aprender e ensinar com textos de alunos. 3. ed., vol. I, São Paulo: Cortez, 2000.

STÉDILE, J.P.; FERNANDES, B.M. Brava gente. A trajetória do MST e a luta pela terra no Brasil. São Paulo: Perseu Abramo, 1999.

et. al. Entrevista explosia: Terra de todos. São Paulo: Revista Caros Amigos, São

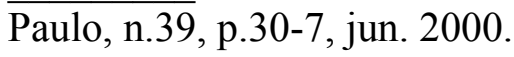

n. 2, 2003. SETOR DE EDUCAÇÃO DO MST. Dossiê MST Escola. São Paulo: Expressão Popular, 2005.

. Somos sem-terra, pra soletrar a liberdade. Caderno do Educando, São Paulo, SPOLIN, V. Improvisação para o teatro. 4. ed., 2ª reimpressão, São Paulo: Perspectiva, 2005. 349 p.

THOMPSON, E. A formação da classe operária inglesa. A árvore da liberdade. Rio de Janeiro: Paz e Terra, 1987, vol.1.

VENTRELLA, R.; BORTOLOZZO, S. Frans Krajberg. São Paulo: Moderna, 2006.

VENEZIA, M. Leonardo da Vinci - Coleção Mestres da Arte. São Paulo: Moderna, 1996.

VIEIRA, E.P. Primeira antologia da poesia e da música dos sem-terra. 2006 (Documento não-publicado).

VYGOTSKY, L.S. Formação social da mente. São Paulo: Martins Fontes, 1989.

Pensamento e linguagem. Lisboa: Antídoto, 1979. 
BARROS, J. de Vida no acampamento. Caros Amigos. São Paulo, n. 6 out. 2000. Especial MST

JORNAL dos Trabalhadores Rurais Sem-Terra. Ano XXV, n. 267, nov. 2006.

SALLES JR., WALTER. Franz Krajcberg: o Poeta dos Vestígios. Brasil. Videofilmes, 1987. VHS.

SALGADO, S. Disponível em: < http://www.unicef.org/brazil/sebastiao.htm>. Acesso em: 9 set. 2007.

SALGADO, S. Disponível em: < http://www.amazonasimages.com/menu_pg.html $>$. Acesso em: 9 set. 2007.

SALGADO, S. Disponível em: <http://www.companhiadasletras.com.br/20anos/ /autores.php3?autor=Sebasti\%E3o\%20Salgado>. Acesso em: 9 set. 2007.

SALGADO, S. Disponível em: < http://www.terra.com.br/sebastiaosalgado/>. Acesso em: 9 set. 2007.

SAMPAIO, P.A. A mística. Banco de dados preparado por Else P. Vieira. In IMAGENS E VOZES DA DESPOSSESSÃO: a luta pela terra e a cultura emergente do MST. Estudos, depoimentos e referências, no ar desde 2003. Disponível em $<\mathrm{http}: / / \mathrm{www}$.landlessvoices.org/vieira/archive-05.phtml? $\mathrm{rd}=\mathrm{MSTICAOF} 657 \& \mathrm{ng}=\mathrm{p} \& \mathrm{sc}=3 \& \mathrm{th}=42 \& \mathrm{se}=0>$. Acesso em :12 jun. 2006.

SCHENBERG, M. Pensando a arte. São Paulo: Nova Stella, 1988.

SEVERINO, A. J. Metodologia do trabalho científico. São Paulo: Cortez, 2002 22. ed.

WALTY, I. L.; CURY, M.Z.F. Intertextualidade. Disponível em $<$ http://www.fcsh.unl.pt/edtl/verbetes/I/intertextualidade.htm>. Acesso em: 5 jan. 2007.

\section{Materiais Educativos}

ASSOCIAÇÃO BRASIL 500 ANOS. Brasil+500 Mostra do redescobrimento (material do professor). São Paulo: 2000.

ASSOCIAÇÃO BRASIL 500 ANOS - Artes visuais. Brasil +500 Mostra do Redescobrimento. Catálogo Aprendiz de Arte. São Paulo: 2000.

CENTRO CULTURAL BANCO DO BRASIL. Antes: histórias da pré-história. (folheto) São Paulo: CCBB, 2005.

BACON, F. Estudo para retrato. 1978. São Paulo: XXIV Bienal de São Paulo - núcleo educação, 1998. 1 reprodução em off set, color, $42,5 \mathrm{~cm}$ x28,5 cm. 
CÉZANE, P. Auto-retrato com chapéu. [1979-1882]. São Paulo: Caras, 1998. 1 reprodução em off set, color, $42,5 \mathrm{~cm} \times 28,5 \mathrm{~cm}$.

DA VINCI, L. A Gioconda in A GRANDE arte na pintura. Rio de Janeiro. Salvat, 1987

DELACROIX. Auto-retrato. [1835-1837]. São Paulo: Caras, 1998. 1 reprodução em off set, color, $42,5 \mathrm{~cm} \times 28,5 \mathrm{~cm}$.

GAUGIN, P. Auto-retrato com auréola. 1889. São Paulo: Caras, 1998. 1 reprodução em off set, color, $42,5 \mathrm{~cm} \times 28,5 \mathrm{~cm}$.

ITAÚ CULTURAL. Material de Apoio ao Professor. Arte e Sociedade: uma relação polêmica. São Paulo: Itaú Cultural, s.d

MAGRITTE, R. La clef dês champs, 1963. Paris: C. H./Adagp et Flamarion 4, 1999. 1 reprodução em off set, color, $60 \mathrm{~cm}$ x $48 \mathrm{~cm}$.

MATISSE, H. Paysage vu d'une fenêtre, 1912. Germany: Neues Verlag, 1998. 1 reprodução em off set, color, $60 \mathrm{~cm} \mathrm{x} 48 \mathrm{~cm}$.

. Femme on divan, 1920. Germany: Neues Verlag, 1998. 1 reprodução em off set, color, $60 \mathrm{~cm} \times 48 \mathrm{~cm}$.

. Conversation, 1909-11. Germany: Neues Verlag, 1998. 1 reprodução em off set, color, $60 \mathrm{~cm} \times 48 \mathrm{~cm}$.

ÓRION, Alexandre. Ossário. Apresenta vídeo, imagens e críticas sobre a intervenção urbana Disponível em <www.alexandreorion.com.br > Acesso em 4 de maio de 2007.

ÓRION, Alexandre. Metabiótica. Apresenta vídeo, imagens e críticas sobre a intervenção urbana Disponível em <www.alexandreorion.com.br> Acesso em 4 de maio de 2007.

PICASSO, P. Auto-retrato. 1907. São Paulo: Caras, 1998. 1 reprodução em off set, color, $42,5 \mathrm{~cm} \times 28,5 \mathrm{~cm}$.

PARENTE, Letícia. Transformação: Pícnico/Astênico, 1977. Disponível em $<$ http://www.mac.usp.br/projetos/arteconceitual/parente.htm>. Acesso em 4 mai. 2007

PORTINARI, C. O café. 1935. São Paulo: Caras, 1998. 1 reprodução em off set, color, $42,5 \mathrm{~cm} \times 28,5 \mathrm{~cm}$.

QUINTANA, Mário. O auto-retrato. Pesquisa de

$<$ http://www.casadobruxo.com.br/poesia/m/auto1.htm> Acesso em 4 de maio de 2007.

REMBRANDT. Auto-retrato. 1661. São Paulo: Caras, 1998. 1 reprodução em off set, color, $42,5 \mathrm{~cm} \times 28,5 \mathrm{~cm}$.

XXIV BIENAL DE SÃO PAULO - Núcleo Educação. A Educação Pública e a XXIV Bienal de São Paulo. São Paulo: Fundação Bienal de São Paulo, 2000. 
SESC PINHEIROS. A conquista do espaço. (folheto). São Paulo: Sesc, Jul. 2007 